\title{
Regulatory Analysis on Criteria for the Release of Patients Administered Radioactive Material
}

\section{Final Report}

Manuscript Completed: April 1996

Date Published: February 1997

S. Schneider, S. A. McGuire

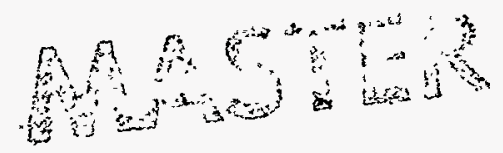

4...

Division of Regulatory Applications

Office of Nuclear Regulatory Research

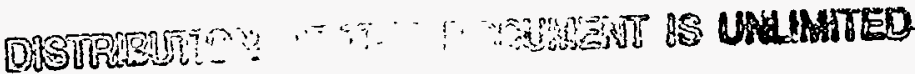

U.S. Nuclear Regulatory Commission

Washington, DC 20555-0001

\section{DISCLAIMER}

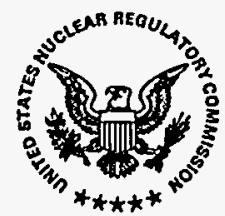

This report was prepared as an account of work sponsored by an agency of the United States Government. Neither the United States Government nor any agency thereof, nor any of their employees, makes any warranty, express or implied, or assumes any legal liability or responsibility for the accuracy, completeness, or usefulness of any information, apparatus, product, or process disclosed, or represents that its use would not infringe privately owned rights. Reference herein to any specific commercial product, process, or service by trade name, trademark, manufacturer, or otherwise does not necessarily constitute or imply its endorsement, recommendation, or favoring by the United States Government or any agency thereof. The views and opinions of authors expressed herein do not necessarily state or reflect those of the United States Government or any agency thereof. 


\section{DISCLAIMER}

Portions of this document may be illegible in electronic image products. Images are produced from the best available original document. 


\section{DISCLAIMER}

This report was prepared as an account of work sponsored by an agency of the United States Government. Neither the United States Government nor any agency thereof, nor any of their employees, make any warranty, express or implied, or assumes any legal liability or responsibility for the accuracy, completeness, or usefulness of any information, apparatus, product, or process disclosed, or represents that its use would not infringe privately owned rights. Reference herein to any specific commercial product, process, or service by trade name, trademark, manufacturer, or otherwise does not necessarily constitute or imply its endorsement, recommendation, or favoring by the United States Government or any agency thereof. The views and opinions of authors expressed herein do not necessarily state or reflect those of the United States Government or any agency thereof. 


\begin{abstract}
This regulatory analysis was developed to respond to three petitions for rulemaking to amend 10 CFR parts 20 and 35 regarding release of patients administered radioactive material. The petitions requested revision of these regulations to remove the ambiguity that existed between the 1-millisievert (0.1-rem) total effective dose equivalent (TEDE) public dose limit in Part 20, adopted in 1991, and the activity-based release limit in 10 CFR 35.75 that, in some instances, would permit release of individuals in excess of the current public dose limit.

Three alternatives for resolution of the petitions were evaluated. Under Alternative 1, NRC would amend its patient release criteria in 10 CFR 35.75 to match the annual public dose limit in Part 20 of 1 millisievert ( $0.1 \mathrm{rem})$ TEDE. Alternative 2 would maintain the status quo of using the activity-based release criteria currently found in 10 CFR 35.75. Under Alternative 3, the NRC would revise the release criteria in 10 CFR 35.75 to specify a dose limit of 5 millisieverts ( $0.5 \mathrm{rem})$ TEDE.

The evaluation demonstrates that adoption of Alternative 1 would be considerably more expensive to the public compared to Alternative 2

(the status quo), primarily due to increased health care costs associated with more patients remaining in the hospital than under the current activity-based requirements. The evaluation also demonstrates that adoption of the 5-millisievert (0.5-rem) dose limit under Alternative 3 would result in a higher net value to the public compared to Alternative 2 (the status quo), primarily due to lower health care costs and the increased psychological benefits to patients and their families by permitting earlier release from the hospital.

Based on this analysis, the decision was made that adoption of the 5-millisievert (0.5-rem) TEDE limit is consistent with the provisions in 10 CFR 20.1301(c), and the recommendations of the International Commission on Radioiogical Protection that an individual be allowed to receive annual doses up to 5 millisieverts ( $0.5 \mathrm{rem}$ ) TEDE under certain circumstances. Further, it no longer restricts patient release to a specific activity, and therefore, permits release of patients with activities that are greater than currently allowed. The primary benefit is in reduced hospital stays that provide emotional benefits to patients and their families, and result in lower health care costs.
\end{abstract}


$\cdots$

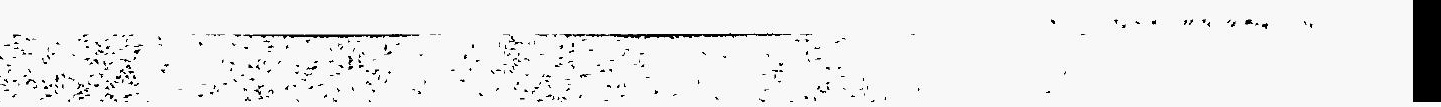




\section{CONTENTS}

ABSTRACT $\ldots \ldots \ldots \ldots \ldots \ldots \ldots \ldots \ldots \ldots \ldots \ldots \ldots \ldots \ldots \ldots \ldots \ldots \ldots \ldots \ldots \ldots$

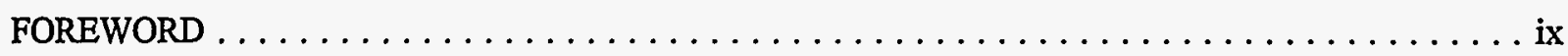

ACKNOWLEDGEMENTS $\ldots \ldots \ldots \ldots \ldots \ldots \ldots \ldots \ldots \ldots \ldots \ldots \ldots \ldots \ldots \ldots \ldots \ldots$

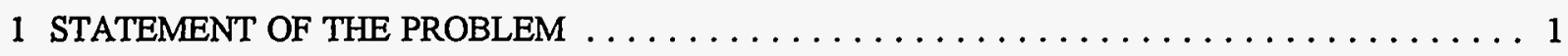

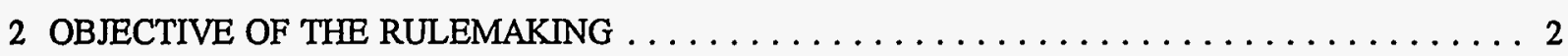

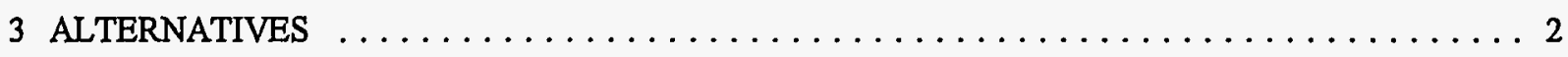

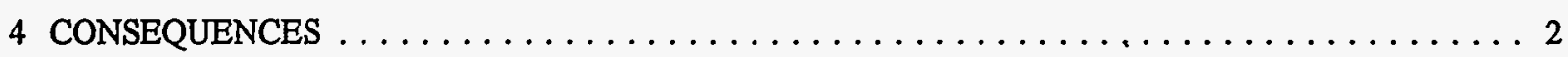

4.1 Current Uses of Radiopharmaceuticals $\ldots \ldots \ldots \ldots \ldots \ldots \ldots \ldots \ldots \ldots \ldots \ldots \ldots$

4.1.1 Diagnostic Administrations $\ldots \ldots \ldots \ldots \ldots \ldots \ldots \ldots \ldots \ldots \ldots \ldots \ldots$

4.1.1.1 Estimates of the Number of Diagnostic Procedures Performed . . . . . . . . 3

4.1.1.2 Age and Sex Distribution of Patients . . . . . . . . . . . . . . . 4

4.1.2 Therapeutic Administrations . . . . . . . . . . . . . . . . . . 6

4.1.2.1 Radiopharmaceuticals Used in Therapy $\ldots \ldots \ldots \ldots \ldots \ldots \ldots \ldots \ldots$

4.1.2.2 Radioactive Materials Used in Permanent Implants (Brachytherapy) . . . . . . . . . 9

4.1.2.3 Summary of Therapeutic Administrations . . . . . . . . . . . 10

4.2 Assessment of Doses to Individuals Exposed to Patients Administered Radioactive

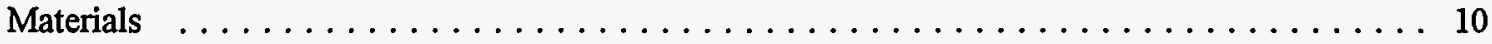

4.2.1 Methodology for Calculating External Gamma Dose $\ldots \ldots \ldots \ldots \ldots \ldots$

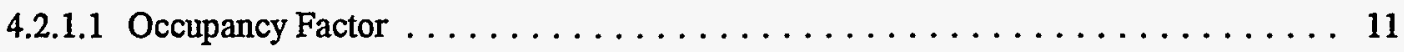

4.2.1.2 Exposure Rate Constant . . . . . . . . . . . . . . . . 13

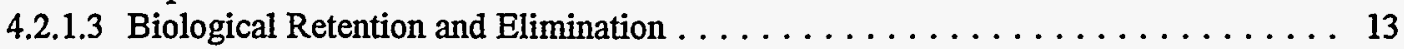

4.2.1.4 Tissue Shielding for Permanent Implants $\ldots \ldots \ldots \ldots \ldots \ldots \ldots \ldots \ldots$

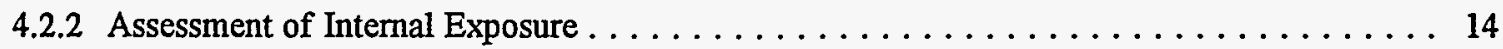

4.2.2.1 Internal Exposure Pathways . . . . . . . . . . . 14

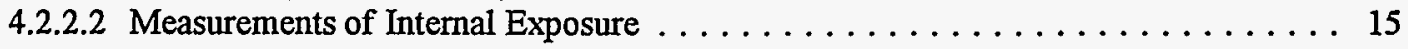

4.2.3 Estimate of Maximum Likely Doses to Individuals Exposed to Patients . . . . . . . 16

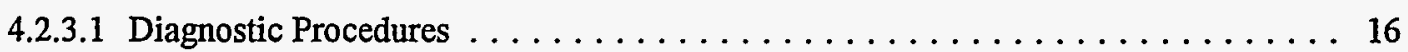

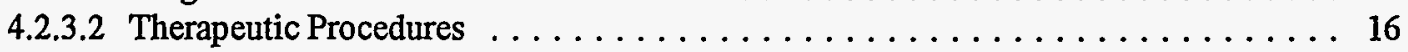

4.2.4 Assessment of Doses to Breast-Feeding Infants $\ldots \ldots \ldots \ldots \ldots \ldots \ldots \ldots \ldots$

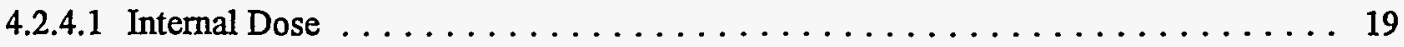

4.2.4.2 External Dose . . . . . . . . . . . . . . . . . . . . . 19 
4.2.4.3 Special Considerations for Iodine-131 Sodium Iodide . . . . . . . . . . 19

4.2.4.4 Summary of Doses to Breast-Feeding Infants $\ldots \ldots \ldots \ldots \ldots \ldots \ldots \ldots \ldots$

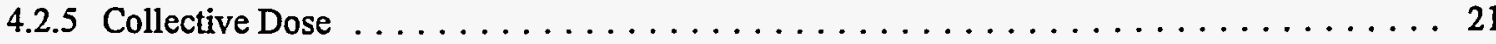

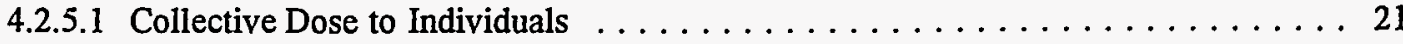

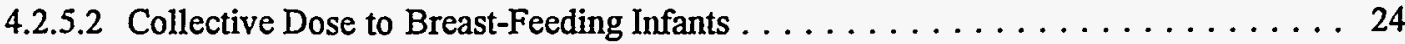

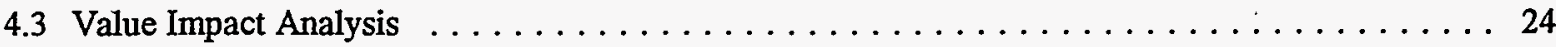

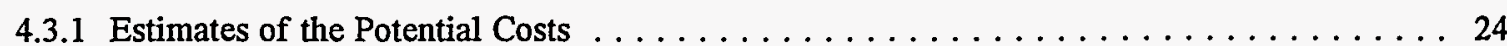

4.3.1.1 Estimates of the Direct Costs of Patient Retention . . . . . . . . . . 24

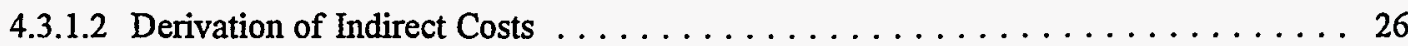

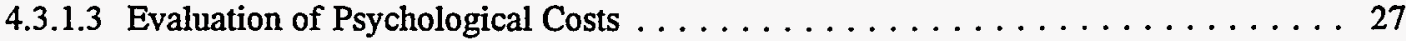

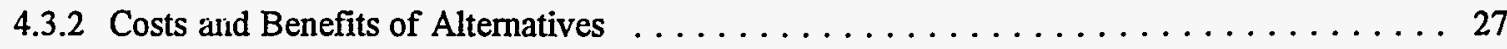

4.4 Evaluation of the Alternatives With Respect to Accepted Radiation Protection

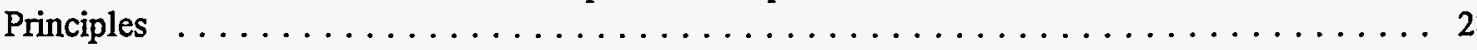

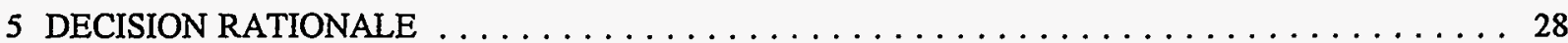

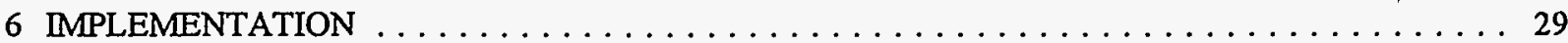

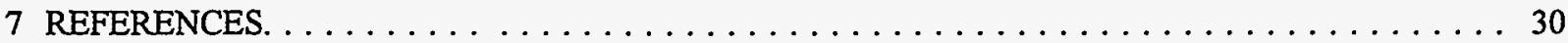

APPENDIX A - Parameters and Calculations for Determining Release Quantities and

Dose Rates for Radionuclides Used in Medicine . . . . . . . . . . . . . . A.1

APPENDIX B - Parameters and Calculations for Determining Instructions to Patients Who

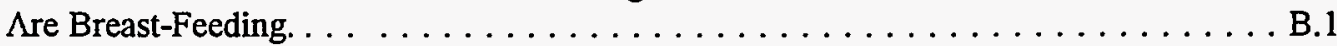

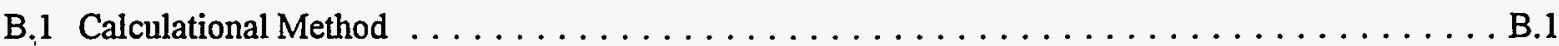

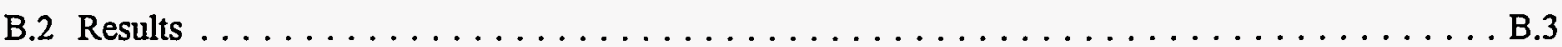

B.2.1 Biokinetic Data for Excretion of Radiopharmaceuticals in Breast Milk . . . . . . . . B.3

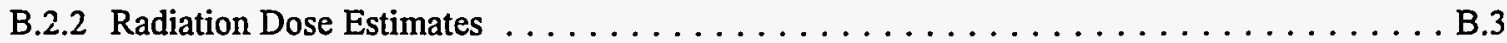

B.3 References. . . . . . . . . . .

Tables

4.1 Estimated Number of Diagnostic Radiopharmaceutical Procedures Performed in the United States Between 1972 and $1982 \ldots \ldots \ldots \ldots \ldots \ldots \ldots \ldots \ldots \ldots \ldots$

4.2 Estimated Radiopharmaceutical Use for Diagnostic Procedures in the United States in $1993 \ldots$. . . 5

4.3 Age and Sex Distribution of Patients Having Nuclear Medicine Examinations . . . . . . . 6 
4.4 Number of Annual Therapeutic Administrations in the U.S. (significant gamma-emitting

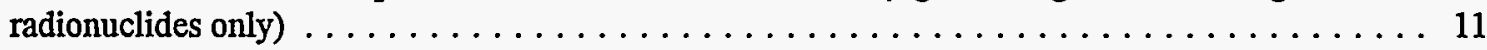

4.5 Family Doses from Patients Treated with Iodine- 131 for Thyroid Carcinoma $\ldots \ldots \ldots \ldots \ldots$

4.6 Iodine-131 Biological Retention and Elimination Parameters for Hyperthyroidism, Thyroid

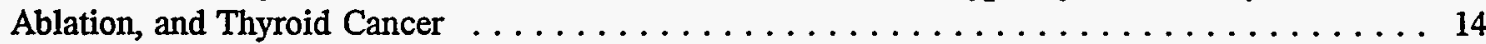

4.7 Maximum Likely Doses to Total Decay to Exposed Individuals from Diagnostic Procedures . . . 17

4.8 Maximum Likely Doses to Total Decay to Exposed Individuals from Therapeutic Procedures Assuming No Hospitalization $\ldots \ldots \ldots \ldots \ldots \ldots \ldots \ldots \ldots \ldots \ldots \ldots \ldots \ldots \ldots$

4.9 Estimates of Collective Dose from Therapeutic Radioiodine Procedures for Alternative 1:

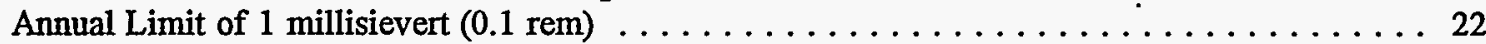

4.10 Estimates of Collective Dose from Therapeutic Radioiodine Procedures for Alternative 2: Limits of 1,110 megabecquerels ( 30 millicuries) or 0.05 millisievert $(5$ millirems $) / \mathrm{hr} \ldots \ldots \ldots 22$

4.11 Estimates of Collective Dose from Therapeutic Radioiodine Procedures for Alternative 3:

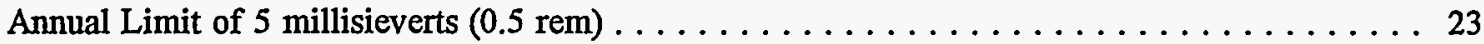

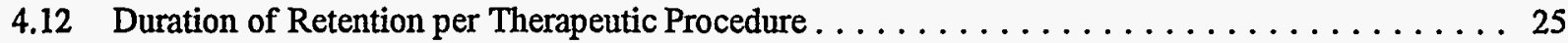

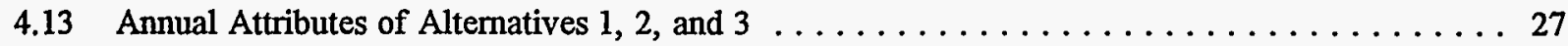

4.14 Annual Costs and Benefits of Alternatives 1 and 3 Compared to Alternative 2

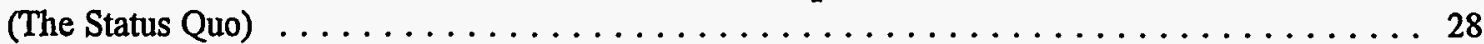

A.1 Half-Lives and Exposure Rate Constants of Radionuclides Used in Medicine $\ldots \ldots \ldots \ldots$. . . .

A.2 Exposure Rate Constants, Release Activities, and Release Dose Rates $\ldots \ldots \ldots \ldots \ldots$ A.2

B.1 Effective Dose Equivalents to Newborns and One-Year-Olds from Infant's Intake of

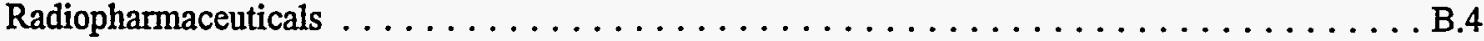

B.2 Excretion Fractions and Biological Half-Lives for Radiopharmaceuticals Excreted in Breast Milk

B.3 Biological and Physical Parameters Used to Calculate the Total Activity Ingested and Internal Radiation Doses Received from the Intake of Radiopharmaceuticals in Breast Milk . . . B.8

B.4 Total Activity Ingested and Internal Radiation Doses Received from the Intake of Radiopharmaceuticals in Breast Milk Under Different Interruption Schedules

B.5 Potential Doses to Breast-Feeding Infants from Radiopharmaceuticals Administered to a Woman if No Interruption of Breast-Feeding and Recommendations on Interruption of Breast-Feeding 


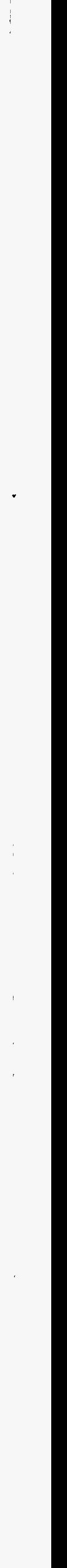




\section{FOREWORD}

This regulatory analysis was developed to respond to three petitions for rulemaking to amend 10 CFR parts 20 and 35 regarding release of patients administered radioactive material. The petitions requested revision of these regulations to remove the ambiguity that existed between the 1-millisievert (0.1-rem) total effective dose equivalent (TEDE) public dose limit in Part 20, adopted in 1991, and the activity-based release limit in 10 CFR 35.75 that, in some instances, would permit release of individuals in excess of the current public dose limit.

In order for the NRC staff to assess the costs and benefits associated with a change in the criteria for the release of patients administered radioactive materials, it was necessary to obtain extensive information about the radionuclides used for the diagnosis or treatment of disease.

This report represents a compilation of this, and other information on the release of patients administered radioactive materials, such as the estimate of maximum likely doses to individuals exposed to these patients, assessment of doses to breast-feeding infants, the corresponding collective doses, and the costs and benefits of a release criteria that is dose based compared to one that is activity based.

This report contains information on the release of patients administered radioactive material that was considered by the NRC staff for the rulemaking on radiological criteria for patient release. The results, approaches and methods described in this final NUREG are provided for informacion only.

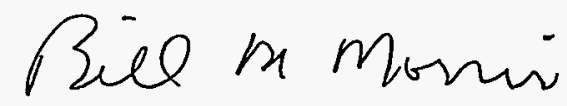

Bill M. Morris, Director Division of Regulatory Applications Office of Nuclear Regulatory Research 
and 


\section{ACKNOWLEDGEMENTS}

Much of the statistical and technical information required for this analysis is not available in the open literature. In such instances, information was obtained directly from technical experts. The following individuals are acknowledged for their cooperation and contribution of technical information and data.

R. Atcher, Ph.D., Radiation and Cellular Oncology Department., University of Chicago, Chicago, IL

K. Behling, S. Cohen and Associates, McLean, VA

U. H. Behling, S. Cohen and Associates, McLean, VA

D. Flynn, M.D. (NRC Advisory Committee on Medical Use of Isotopes), Massachusetts General Hospital, Boston, MA

D. Goldin, S. Cohen and Associates, McLean, VA

W.R. Hendee, Ph.D., Dean of Research, Medical College of Wisconsin, Milwaukee, WI

P. Holahan, Ph.D., U.S. Nuclear Regulatory Commission, Washington, DC

C. Jacobs, President, Theragenics, Norcross, GA

F.A. Mettler, M.D., Department of Radiology, University of New Mexico, School of Medicine, Albuquerque, NM

K.L. Miller, CHP, Professor of Radiology and Director, Division of Health Physics, Milton Hershey Medical Center, Hershey, PA

R. Nath, Ph.D., Professor of Yale University, School of Medicine, and President of the American Association of Nuclear Physics, New Haven, CT

M.P. Nunno, Ph.D., CHP, Cooper Hospital, University Medical Center, Camden, NJ
P. Paras, Ph.D., Food and Drug Administration, Center for Devices and Radiology Health, Rockville, MD

M. Pollycove, M.D., Visiting Medical Fellow, U.S. Nuclear Regulatory Commission, Washington, DC

G.E. Powers, Ph.D., Office of Nuclear Regulatory Research, U.S. Nuclear Regulatory Commission, Washington, DC

M. Rosenstein, Ph.D., Food and Drug Administration, Center for Devices and Radiology Health, Rockville, MD

J. St.Germain, Radiation Safety Officer, Memorial Sloan Kettering, New York City, NY

B.A. Siegel, M.D., (Chairman, NRC Advisory Committee on Medical Use of Isotopes) Director, Division of Nuclear Medicine, Mallinckrodt Institute of Radiology, Washington University Medical Center, St. Louis, MO

M.G. Stabin, Ph.D., CHP, Radiation Internal Dose Information Center, Oak Ridge Institute for Science and Education, Oak Ridge, TN

D. Steidley, Ph.D., CHP, Medical Health Physicist, Department of Oncology, St. Barnabas Medical Center, Livingston, NJ

J. Stubbs, Ph.D., Radiation Internal Dose Information Center, Oak Ridge Institute for Science and Education, Oak Ridge, TN

K. Suphanpharian, Ph.D., President, Best Industries, Springfield, VA

R.E. Toohey, Ph.D., CHP, Director, Radiation Internal Dose Information Center, Oak Ridge Institute for Science and Education, Oak Ridge, TN 


\section{STATEMENT OF THE PROBLEM}

Each year in the United States, radioactive pharmaceuticals or compounds or radioactive implants are administered to roughly 8 to 9 million patients for the diagnosis or treatment of disease. These people can expose others around them to radiation until the radioactive material has been excreted from their bodies or has decayed away.

NRC's patient release criteria in 10 CFR 35.75 , "Release of Patients or Human Research Subjects Containing Radiopharmaceuticals or Permanent Implants," are as follows:

(a) A licensee may not authorize release from confinement for medical care any patient or human research subject administered a radiopharmaceutical until either: (1) The measured dose rate from the patient or the human research subject is less than 5 millirems per hour at a distance of 1 meter; or (2) The activity in the patient or the human research subject is less than 30 millicuries; (b) A licensee may not authorize release from confinement for medical care of any patient or human research subject administered a permanent implant until the measured dose rate from the patient or the human research subject is less than 5 millirems per hour at a distance of 1 meter."

On May 21, 1991, the NRC published a final rule that amended 10 CFR Part 20, "Standards for Protection Against Radiation" (56 FR 23360). The rule contained limits on the radiation dose for members of the public in 10 CFR 20.1301. However, when 10 CFR Part 20 was issued, there was no discussion in the supplemental information on whether or how the provisions of 10 CFR 20.1301 were intended to apply to the release of patients, thereby creating the need to address this issue.

Because some licensees were uncertain what effect the revised 10 CFR Part 20 would have on patient release criteria, three petitions for rulemaking were received on this issue. The first petition, submitted by Dr. Carol S. Marcus (PRM-20-20, 56 FR 26945), requested that the NRC:

(1) Raise the annual radiation dose limit in 10 CFR 20.1301(a) for individuals exposed to radiation from patients receiving radiopharmaceuticals for diagnosis or therapy from 1 millisievert $(0.1 \mathrm{rem})$ to 5 millisieverts $(0.5 \mathrm{rem})$.

(2) Amend $10 \mathrm{CFR}$ 35.75(a)(2) to retain the 1,110-megabecquerel (30-millicurie) limit for iodine-131 (I-131), but provide an activity limit for other radionuclides consistent with the calculational methodology employed in the National Council on Radiation Protection and Measurements (NCRP) Report No. 37, "Precautions in the Management of Patients Who Have Received Therapeutic Amounts of Radionuclides" (NCRP70).

(3) Delete 10 CFR 20.1301(d), which requires licensees to comply with provisions of EPA's environmental regulations in 40 CFR Part 190 in addition to complying with the requirements of 10 CFR Part 20.

The second petition, submitted by the American College of Nuclear Medicine (ACNM) (PRM-35-10, 57 FR 8282, as revised by PRM-35-10A,

57 FR 21043), requested that the NRC:

(1) Adopt a dose limit of 5 millisieverts (0.5 rem) for individuals exposed to patients who have been administered radiopharmaceuticals.

(2) Permit licensees to authorize release from hospitalization any patient administered a radiopharmaceutical even if the activity in the patient is greater than 1,110 megabecquerels (30 millicuries) by defining "confinement" to include confinement in a private residence.

A third petition (PRM-35-11, 59 FR 37950) dealing, in part, with these same issues was submitted by the American Medical Association (AMA). The main point of the petition is that the radiation dose limits in 10 CFR 20.1301 should not apply to individuals exposed to the patient.

Since the petitions submitted by Dr. Marcus, the ACNM, and the AMA all address the patient release criteria in 10 CFR 35.75, the NRC decided to resolve these petitions in a single rulemaking. 


\section{OBJECTIVE OF THE RULEMAKING}

The objective of this rulemaking is to respond to the three petitions for rulemaking by amending, as deemed appropriate, the patient release criteria in 10 CFR 35.75.

\section{ALTERNATIVES}

As the petitions and the public comments that were submitted to the Commission on the petitions made clear, some licensees were uncertain about whether dose limits imposed by 10 CFR 20.1301(a) or the patient release criteria established by 10 CFR 35.75 govern patient release. In the Commission's view, 10 CFR 35.75 governs patient release as explained in the Notice of Proposed Rulemaking (59 FR 30724). The public comments received on the three petitions and on the Notice of Proposed Rulemaking also made it clear that the majority of commenters favored an annual dose limit of 5 millisieverts (0.5 rem). Given that 10 CFR Part 35 was deemed to be the controlling regulation, the Commission was faced with the decision regarding the regulatory approach to be pursued in 10 CFR 35.75. To evaluate the issues raised by the petitioners and those who commented on the requests made by the petitioners and the Notice of Proposed Rulemaking, the NRC determined that the following alternatives should be evaluated:

- Alternative 1: 1 millisievert (0.1 rem) total effective dose equivalent

This alternative evaluates a dose limit of 1 millisievert ( $0.1 \mathrm{rem})$ to an individual exposed to a patient as the limiting factor for determining when a patient may be released from the licensee's control.

- Alternative 2: $<1,110$ megabecquerels (30 millicuries) or $<0.05$ millisievert $(5$ millirems $) / \mathrm{hr}$ at 1 meter

In this alternative, the current patient release criteria in 10 CFR 35.75 are evaluated as the controlling requirements for determining when a patient may be released from the licensee's control.

- Alternative 3: 5 millisieverts $(0.5 \mathrm{rem})$ total effective dose equivalent

This alternative evaluates a dose limit of 5 millisieverts $(0.5 \mathrm{rem})$ to an individual exposed to a patient as the limiting factor for determining when a patient may be released from the licensee's control.

\section{CONSEQUENCES}

To evaluate the impacts of the three alternatives, it is necessary to determine which current procedures involving the administration of radiopharmaceuticals or permanent implants might be affected by the imposition of a dose limit of 1-millisievert (0.1-rem) total effective dose equivalent for individuals exposed to released patients. For convenience, procedures involving the administration of radioactive materials to patients may be classified as: (1) diagnostic procedures involving administration of radiopharmaceuticals to obtain information about normal and pathological processes in the patient; or, (2) therapeutic procedures involving administration of radiopharmaceuticals or implantation of a radioactive source to destroy diseased tissue in the patient.

\subsection{Current Uses of Radiopharmaceuticals}

Radiopharmaceuticals can be defined as "drugs" that are radioactive. Although radiopharmaceuticals, diagnostic or therapeutic, may be classified as drugs, it should be noted that radiopharmaceuticals are not given for the purpose to exert any pharmacological action.

Radiopharmaceuticals are generated from two sources: nuclear reactors and accelerators. Nuclear reactors can produce radionuclides through neutron capture reactions (e.g., (n, $\gamma$ ), $(\mathrm{n}, \mathrm{p})$, and $(\mathrm{n}, \alpha)$ ), as well as by nuclear fission $(n, f)$. Other radiopharmaceuticals are accelerator 
produced, in which a highly pure target material is bombarded with protons, deuterons, or alpha particles. Many have relatively short half-lives. Some radiopharmaceuticals may be produced by either reactor or accelerator (e.g., palladium-103 (Pd-103) and iodine-125 (I-125)). The choice in production method is dictated by cost considerations and vendor access to a high neutron flux reactor facility. While most iodine- 125 has in the past and continues to be produced by reactors, the production of palladium-103 has shifted from reactor to accelerator (personal communication, C. Jacobs, August 1993).

\subsubsection{Diagnostic Administrations}

\subsubsection{Estimates of the Number of Diagnostic Procedures Performed}

Estimates regarding the frequency and total number of diagnostic nuclear medicine procedures have been reported over the years in several studies reviewed and analyzed by Mettler, et al. (ME85). Among the earliest data reported was a study supported by the American College of Radiology (ACR75), which reflects data collected in 1972 by J. Lloyd Johnson Associates.

Additional data for the years 1973 and 1975 were obtained in a similar fashion and also published in the American College of Radiology Manpower Survey (ACR82).

In 1975, the Bureau of Radiological Health (BRH; now the Center for Medical Devices and Radiological Health, CDRH) of the United States Food and Drug Administration initiated a pilot study that surveyed information reported by six hospitals to the Medically Oriented Data System (MODS). This project was later expanded to include 26 stratified hospitals that provided data for 1977 and 1978 (FDA85).

Comprehensive data on 1980 diagnostic imaging procedures were obtained by J. Lloyd Johnson Associates by mail questionnaire using a stratified random sample of general hospitals and selected office practices in the U.S. (JO83). The sample included 6,109 hospitals and was estimated to reflect about 90 percent of the total diagnostic imaging examinations. Additional studies were conducted by the BRH for the years 1980, 1981, and 1982. The hospital-based survey was called the Radiation Experience Data (RED 1 and
RED 2 studies) (ME85). The RED 1 study examined the computer billing records of 81 hospitals. Data for the subsequent RED 2 study reflect information obtained by mail survey from 500 hospitals.

Data for 1982 were also provided by Parker, et al. (PA84) in which a randomized sample of 10 percent of the U.S. hospitals were surveyed. Although his survey was specifically directed to thyroid examinations, survey data also provided estimates of total examinations.

All of the studies mentioned above are summarized in Table 4.1 and represent hospital data only. However, the exclusion of non-hospital facilities should not significantly affect the accuracy of estimates since less than 1 percent of all nuclear medicine procedures are performed outside hospitals (JO83). Inspection of Table 4.1 reveals several important trends. While the total number of diagnostic procedures has shown a general increase, the number of specific procedures has in some cases dramatically increased or decreased. By 1982, there were fewer radionuclide brain imaging examinations than in 1972, undoubtedly due to replacement by computerized tomography (ME85). For the same period, liver imaging increased tenfold. The largest percent increase involves cardiovascular imaging, which increased from an estimated 25,000 procedures in 1972 to about 950,000 in 1982. Other procedures such as renal, lung, and tumor imaging have experienced only modest increases in numbers.

A search of the open literature revealed no recent comprehensive studies to assess more current U.S. use of radiopharmaceuticals. It is generally thought, however, that the frequency and usage of radiopharmaceuticals have stabilized because of the competing technologies of computerized tomography, magnetic resonance imaging, and gray-scale ultrasound (personal communication, F.A. Mettler, March 1993). For this report, the most recent RED 2 frequency distribution and the cumulative frequency of 16 diagnostic nuclear medicine procedures per one-thousand population will be used to estimate current usage. Table 4.2 provides frequency estimates of diagnostic procedures adjusted to reflect the 1993 U.S. population, which is projected at $256,466,000$ by the United States Bureau of the Census. 
Table 4.1 Estimated Number of Diagnostic Radiopharmaceutical Procedures Performed in the United States Between 1972 and 1982

\begin{tabular}{|c|c|c|c|c|c|c|c|c|c|}
\hline \multirow[b]{4}{*}{$\begin{array}{l}\text { Examination } \\
\text { Type }\end{array}$} & \multicolumn{9}{|c|}{ Year } \\
\hline & 1972 & 1973 & 1975 & 1978 & 1980 & 1980 & 1981 & 1982 & 1982 \\
\hline & \multicolumn{9}{|c|}{$\underline{\text { Source }}$} \\
\hline & ACR & ACR & ACR & MODS & Johnson & RED 1 & RED 2 & RED 2 & Parker \\
\hline Brain & $1260^{*}$ & 1510 & 2120 & 1546 & 870 & 1176 & 1038 & 812 & $\ldots$ \\
\hline Hepatobiliary & 26 & -- & -- & --- & -- & --- & 109 & 179 & -- \\
\hline Liver & 455 & 535 & 676 & 1302 & 1180 & 1399 & 1445 & 1424 & -- \\
\hline Bone & 81 & 125 & 220 & 1160 & 1270 & 1307 & 1613 & 1811 & -- \\
\hline Respiratory & 332 & 417 & 597 & 1053 & 830 & 898 & 1095 & 1191 & -- \\
\hline Thyroid & 356 & 460 & 627 & 699 & 650 & 506 & 664 & 677 & 533 \\
\hline Urinary & 108 & 122 & 154 & 205 & 200 & 164 & 402 & 236 & -- \\
\hline Tumor & 10 & 14 & 22 & 166 & 130 & --- & 125 & 121 & -- \\
\hline Cardiovascular & 25 & 33 & 49 & 160 & 580 & 558 & 708 & 950 & -- \\
\hline Other & 686 & 294 & 338 & 120 & 120 & 368 & -- & -- & -- \\
\hline \multirow[t]{2}{*}{ Total } & 3339 & 3510 & 4803 & 6411 & 5830 & 6374 & 7199 & 7401 & 7690 \\
\hline & $(16)^{\dagger}$ & (17) & (22) & (29) & (26) & (28) & (31) & (32) & (33) \\
\hline
\end{tabular}

Source: ME85.

* Numbers not in parenthesis indicate number of examinations $x 1,000$.

$t$ Numbers in parenthesis indicate number of examinations/1,000 population.

The identity, chemical form, and typical quantity administered of radionuclides used for diagnostic in-vivo procedures are cited in Table 4.2 and reflect values cited by Mettler, et al. (ME86). It can be assumed that the typical quantity per examination has not significantly changed since the time of original publication (personal communication, F.A. Mettler, March 1993).

As the results in Table 4.2 indicate, there are approximately 8.2 million diagnostic examinations employing radiopharmaceuticals performed annually in the United States. Of these, more than 85 percent use technetium-99m (Tc-99m) as the label, about 5 percent use xenon-133 (Xe-133), about 5 percent use thallium-201 (Tl-201), about
3 percent use iodine-131 or iodine-123 (I-123), and about 2 percent use gallium-67 (Ga-67).

\subsubsection{Age and Sex Distribution of Patients}

The age and sex distribution of the United States population that underwent nuclear medicine examinations in 1980, as cited by Mettler, et al. (ME86), is shown in Table 4.3. For the period of observation, more than three-fourths of all nuclear medicine examinations were performed on persons over the age of 45 ; nearly 40 percent of these patients were 64 years and older. With the exception of the youngest age category, the percentage of females exceeded males. 
Table 4.2 Estimated Radiopharmaceutical Use for Diagnostic Procedures in the United States in 1993*

\begin{tabular}{|c|c|c|c|}
\hline $\begin{array}{l}\text { Examination Type } \\
\text { (Radiopharmaceutical) }\end{array}$ & $\begin{array}{r}\text { Typic } \\
\text { per Ex } \\
(\mathbf{M B q}) \\
\end{array}$ & $\begin{array}{l}\text { Activity } \\
\text { ination } \\
(\mathrm{mCi})\end{array}$ & $\begin{array}{c}\text { Number of } \\
\text { Examinations } \\
(\times 1,000)\end{array}$ \\
\hline \multicolumn{4}{|l|}{ Brain } \\
\hline 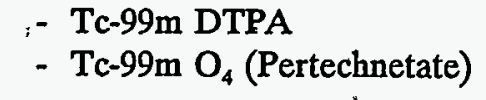 & $\begin{array}{l}740 \\
740\end{array}$ & $\begin{array}{l}(20) \\
(20)\end{array}$ & $\begin{array}{l}450 \\
450\end{array}$ \\
\hline$\frac{\text { Hepatobiliary }}{-. \text { Tc-99m.IDA }}$ & 185 & (5) & 198 \\
\hline \multicolumn{4}{|l|}{ Liver } \\
\hline \multicolumn{4}{|l|}{ Bone } \\
\hline \multicolumn{4}{|l|}{ Lung Perfusion } \\
\hline \multicolumn{3}{|l|}{ Lung Ventilation } & 449 \\
\hline $\begin{array}{l}\text { Thyroid } \\
\text { - Tc-99 } \mathrm{m} \mathrm{O}_{4} \text { (Pertechnetate) } \\
-\mathrm{I}-123 \\
-\mathrm{I}-131\end{array}$ & $\begin{array}{r}185 \\
11.1 \\
3.7\end{array}$ & $\begin{array}{l}(5) \\
(0.3) \\
(0.1)\end{array}$ & $\begin{array}{r}600 \\
75 \\
75\end{array}$ \\
\hline $\begin{array}{l}\frac{\text { Renal }}{\text { - Tc-99m DTPA }} \\
\text { - I-131 Hippuran }\end{array}$ & $\begin{array}{l}740 \\
9.3\end{array}$ & $\begin{array}{l}(20) \\
(0.25)\end{array}$ & $\begin{array}{l}157 \\
105\end{array}$ \\
\hline $\begin{array}{l}\text { Cardiovascular } \\
\text { - Tc-99m RBC } \\
\text { - Tc-99m Phosphate } \\
\text { - Tl-201 Chloride }\end{array}$ & $\begin{array}{l}740 \\
740 \\
111\end{array}$ & $\begin{array}{r}(20) \\
(20) \\
(3)\end{array}$ & $\begin{array}{l}421 \\
211 \\
421\end{array}$ \\
\hline \multicolumn{3}{|l|}{ Tumor } & 134 \\
\hline Total & & & 8,202 \\
\hline
\end{tabular}

* Based on ME86; and personal communication, F. A. Mettler, March 1993, but adjusted for the 1993 United States population. 
Table 4.3 Age and Sex Distribution of Patients Having Nuclear Medicine Examinations

\begin{tabular}{lccc}
\hline Age & $\begin{array}{c}\text { Male } \\
(\%)\end{array}$ & $\begin{array}{c}\text { Female } \\
(\%)\end{array}$ & $\begin{array}{c}\text { Total } \\
(\%)\end{array}$ \\
\hline$<15$ & 0.9 & 0.7 & 1.6 \\
$15-29$ & 3.3 & 4.9 & 8.2 \\
$30-44$ & 5.2 & 8.7 & 13.9 \\
$45-64$ & 15.8 & 21.6 & 37.4 \\
$>64$ & 17.0 & 21.9 & 38.9 \\
\hline
\end{tabular}

Source: ME86.

\subsubsection{Therapeutic Administrations}

Therapeutic use of radioactive materials involves two distinct approaches. The first involves the oral, intravenous, or intracavity administration of a radiopharmaceutical that may subsequently be distributed, concentrated, retained, and eliminated by physical, chemical, and metabolic actions occurring within the body. The second approach involves the implantation of radioactive sources (i.e., seeds) directly into a solid tumor. While both temporary and permanent implants are performed, all patients receiving temporary implants are hospitalized until the implants are removed. Thus, only permanent implants are potentially affected by this rulemaking.

\subsubsection{Radiopharmaceuticals Used in Therapy}

The in-vivo use of radiopharmaceuticals in therapy is based on the ability to differentially deliver lethal radiation doses to the selected target tissue. Most desirable are beta emitters that can deliver intense irradiation of target cells while sparing the surrounding tissues. In contrast to diagnostic procedures for which the gamma emission is essential, the emission of energetic gammas is undesirable for therapeutic purposes since it results in unwanted irradiation of surrounding healthy tissues and doses to individuals in close proximity to the patient. The more significant therapeutic applications are described below.

\section{Hyperthyroidism}

Hyperthyroidism is characterized by an increased production of thyroid hormone. Hyperthyroidism is most commonly associated with Graves' Disease. Graves' Disease is an autoimmune disease in which the body's own immune system is directed against cellular and secretory products of the thyroid gland. Hyperthyroidism can also be the result of excessive hormone production by a single "toxic" nodule, thyroid carcinomas, and medications inclusive of potassium iodide.

Hyperthyroidism is not a condition reportable to public health agencies. As a result, data on rates of occurrence and treatment must be inferred. Incidence of hyperthyroidism is reported at 3 per 10,000 adults per year, with peak incidence occurring between 30 and 50 years of age (DG79).

From the most recent data (1990) available from the United States Bureau of the Census, it can be assumed that about 75 percent of the United States population (approximately 191,500,000 persons) is 18 years of age or older. Thus, it can be estimated that about 57,500 individuals per year require medical treatment for hyperthyroidism.

Although medical treatment may in some cases involve the use of anti-thyroid drugs or surgery, it may be assumed that about 85 percent of the cases of hyperthyroidism are treated with therapeutic doses of iodine-131 (personal communication, M. Pollycove, November 1993). The resulting estimate is about 50,000 treatments per year.

In the past, therapeutic quantities of iodine- 131 for treatment of hyperthyroidism tended to be of a magnitude (185 to 550 megabecquerels ( 5 to 15 millicuries)) that would reduce the 
hormone production of the hyperactive thyroid gland to normal levels. However, experience demonstrated that over a period of years the therapeutically induced euthyroidal condition (normal or healthy thyroid) deteriorated to one of hypothyroidism requiring thyroid hormone replacement therapy. As a result, today hyperthyroid therapy also involves the use of iodine-131 to ablate the thyroid. Approximately 50 percent of all hyperthyroid patients undergo ablation (personal communication, $M$. Pollycove, January 1996). Typically, activities in the range from 550 to 1,110 megabecquerels (15 to 30 millicuries) are used but about 2 percent of all patients require as much as 2,220 megabecquerels (60 millicuries), the maximum typically administered. Such doses quickly result in the total loss of thyroid function and the patient is given hormone replacement therapy from the onset (personal communications, F. A. Mettler, March 1993 and M. Pollycove, January 1996).

\section{Thyroid Nodules}

Single or multiple nodules of sufficient size may cause obvious enlargement of the thyroid. A nodule(s) refers to a replacement of the normal homogeneous cytostructure of the thyroid with a histologic pattern ranging from colloid-filled cysts and colloid adenomas to follicular adenomas. Since the incidence is 4 to 5 times as great in women as in men, and since it develops and progressively increases in size during life, it is most frequently found in females 50 to 70 years of age. It is not uncommon for nodules to remain undetected until a post-mortem examination.

Small nodules in euthyroid subjects require no therapy. If the gland is grossly enlarged and causes a cosmetic problem or tracheal compression, treatment may be indicated along with thyroid hormone replacement therapy.

A small percentage of thyroid nodules tend to produce thyroid hormones uncontrollably and in excess (i.e., the nodule is not under the regulatory control of the pituitary gland and is clinically referred to as toxic nodular goiter). The presence of these autonomously functioning thyroid nodules leads to hyperthyroidism (i.e., thyrotoxicosis).

Toxic nodular goiter, like Graves' Disease, may be treated surgically (i.e., thyroidectomy) or by therapeutic dose(s) with radioactive iodine.
Estimates of the frequency of radioactive iodine treatment for this condition are included under the estimates for hyperthyroid treatment above.

\section{Thyroid Cancer}

There is no nationwide cancer registry that accurately defines the number of new cases of cancer diagnosed each year. However, the American Cancer Society (ACS) annually publishes data on cancer incidence and patient survival based on information provided by the National Cancer Institute's Surveillance, Epidemiology, and End Results (SEER) program.

The ACS estimates of United States cancer cases diagnosed for 1992, are based on age-specific incidence rates from the SEER program for 1986 to 1988 applied to the Census Bureau's population projections for 1992. The ACS's estimate of new thyroid cancers in 1992, is 12,500 (ACS93). This report assumes that 100 percent of these cases will be treated by the surgical removal of thyroid gland tissue (i.e., thyroidectomy). Following surgery, about 20 percent of these cases will not require additional thyroid cancer therapy but about 80 percent will require additional therapeutic administrations of iodine-131 to eliminate residual thyroid cancer tissue (personal communication, M. Pollycove, January 1996). Therefore, this report assumes that about 10,000 cases per year will be treated with therapeutic doses of iodine- 131 .

The quantities of iodine-131 used in thyroid cancer therapy depend upon the type of cancer, the status of the cancer, and the degree of uptake and retention of iodine- 131 by residual cancerous thyroid tissue. As a result, current therapeutic quantities range from 1,850 to 11,100 megabecquerels (50 to 300 millicuries) (personal communications, F.A. Mettler and K.L. Miller, March 1993). The typical quantity administered is 5,500 megabecquerels (150 millicuries) (personal communication, $M$. Pollycove, January 1996).

\section{Therapy for Polycythemia Vera}

Since the introduction of radiophosphorus ( $\mathrm{P}-32)$ in 1936, patients with polycythemia vera have been treated successfully with this radioisotope to control 
rather than cure this disease. Polycythemia vera is a relatively rare disease that is characterized by an autonomous proliferation of marrow cells leading to an over production of red blood cells, white blood cells, and platelets. Typically, phosphorous-32 is administered intravenously in doses of 111 to 185 megabecquerels ( 3 to 5 millicuries) per treatment over a period of time with average cumulative quantities of 740 megabecquerels (20 millicuries) per patient.

\section{Bone Therapy}

Since the use of radioactive strontium for the treatment of bone metastases was first described in early 1942 (PE42), bone therapy has included other radionuclides. Bone therapy may involve the treatment of primary bone tumors such as osteosarcoma (BL87) in which bone-seeking radiopharmaceuticals are in fact tumor seeking. Bone therapy may also be the treatment of painful skeletal metastases, which may be palliated by bone-seeking radionuclides. Although the literature references the palliative and tumor therapeutic use of these radionuclides (phosphorous-32: CH80, RO77; strontium-89 (Sr-89): BL88, KL87, RO87, ROE90, SI85; rhenium-186 (Re-186): KE87, MA88, SC90; samarium-153 (Sm-153): LA90, TU89), there are no databases and no studies have been performed that would allow quantitative estimates regarding the number of patients given bone therapy with radiopharmaceuticals. These other therapies are performed so seldom that they have negligible impact in comparison with the radioiodines.

\section{Therapy with Radiolabelled Cells}

For lymphoid cell malignancies, the tumor cells (i.e., lymphocytes) may retain their ability to migrate and recirculate into the lymphoreticular tissues (i.e., spleen, liver, bone marrow, and lymph nodes). The harvesting, labelling, and reinjection of lymphocytes has been demonstrated to deliver therapeutic levels of radiation doses to tumors of the lymphoreticular system (CO87). Indium-114 labelled lymphocytes have a potential therapeutic role in the management of lymphoma, and clinical studies are underway. Because use of this new therapy is not widespread, it will not be considered any further in this analysis.

\section{Intra-Arterial Therapy}

Some primary tumors as well as metastatic lesions are highly vascularized. Direct arterial injection with insoluble radiolabelled particulates that lodge in arterioles and capillaries of the tumor is the basis of this form of therapy (EH87, ZI84). Insoluble carriers of radionuclides that have been clinically tested include iodine-131-labelled oil contrast medium, iodine-131-lipoidal or -ethiodol (PA87), yttrium-90-glass microspheres (HE88), and yttrium-90 (Y-90) resin particles (ROE90). Since these therapies are so seldom used, their impact may be ignored in this analysis.

\section{Intracavitary Tumor Therapy}

For tumors that are spread over the serosal linings of the body cavities or for ascites tumors, one approach to delivering therapeutic doses of radiation is to inject the radiopharmaceutical directly into the body cavity. For this approach, colloids, chelates, and, more recently, monoclonal antibodies labelled with gold-198 (Au-198), phosphorous-32, yttrium-90, or iodine- 131 can be used.

Initially, gold-198 colloids were used, but phosphorous-32 is now preferred due to its longer half-life, more energetic beta particles, and the absence of gamma radiation. Intracavitary radionuclide therapy with phosphorous-32 in quantities of 185 to 370 megabecquerels (5 to 10 millicuries) has been applied to malignancies involving the pleural, pericardial, and peritoneal cavities (JA81, KA81, MA78).

More recently, iodine-131- or yttrium-90-labelled tumor-associated monoclonal antibodies have been used in intracavitary therapy (FI89, PE86, RI90) in doses of 740 to 2,220 megabecquerels (20 to 60 millicuries). Superiority of monoclonal antibodies over colloids is expected due to the enhanced affinity of the labelled antibody for the target cells. At present, these therapies are rarely used and thus have no impact in comparison with radioiodines.

\section{Radioimmunotherapy}

Radioimmunotherapy involves the use of radiolabelled antibodies directed against tumor-specific antigens such as the carcinoembryonic antigen (CEA) and ferritin. 
Only a very limited number of cancer patients have been treated experimentally with radiolabelled antibodies in combination with chemotherapy and external beam irradiation. Among cancers treated are hepatomas, Hodgkin's disease, and non-Hodgkin's lymphoma (LE85, NE90, OR85). In the past, radioimmunotherapy involved the use of iodine-131- and yttrium-90labelled polyclonal antibodies raised against tumor-associated antigens in a variety of animal species. Based on avidity of tumor cells and exposure considerations of the bone marrow, single doses of 370 to 1,110 megabecquerels (10 to 30 millicuries) have been used.

The development of the hybridoma technique by Kohler and Milstein (KO75) has caused significant shift in radioimmunotherapy. The hybridoma technique allows the development of monoclonal antibodies against tumor-associated antigens. At - this time, however, the use of radiolabelled monoclonal antibodies for therapeutic applications has been limited to experimental treatments. At present, these therapies are rarely used and thus have no impact in comparison with the radioiodines.

\subsubsection{Radioactive Materials Used in Permanent Implants (Brachytherapy)}

In-situ radiotherapy may involve permanent implants or brachytherapy. Brachytherapy has been around almost since the discovery of $\mathrm{X}$ rays. Brachytherapy can be divided into temporary implantation using high activity sources or permanent brachytherapy using the interstitial implantation of encapsulated radioactivity. In 1911, Pasteau reported the first treatment of prostate cancer by brachytherapy using radium inserted through a urethral catheter (PA11). Currently, iridium-192 (Ir-192) is the radionuclide of choice for temporary implantation. For temporary implantation, the sources are removed from the patient before the patient is released from licensee control. Radionuclides used for temporary implants are, therefore, of no concern to this report and will not be discussed further.

Over the past 20 years, several radionuclides have been introduced to brachytherapy, allowing for the permanent implantation of radioactive "seeds." Seeds are miniature capsules that are strategically inserted within a solid tumor and over the period of their decay deliver a lethal dose of radiation to tumor cells within a short distance of the implant. The major advantage of brachytherapy over external irradiation in the treatment of solid tumors is the favorable ratio of dose delivered to tumor cells versus normal tissue. This is particularly true of prostate cancer where the surrounding normal tissue includes the bladder, rectum, and urethra. The presence of these normal tissues limits the dose of external beam radiation therapy that can be administered safely to the prostate.

The radionuclides primarily used in permanent implants are iodine-125 and palladium-103. Less frequently used radionuclides include gold-198 and ytterbium-169 (Yb-169).

The most frequently used radionuclide in permanent implants is iodine-125, which has the advantage of an extremely low energy ( $27 \mathrm{keV}$ ) photon and a physical half-life of 60 days. Besides minimizing dose to surrounding healthy tissue, the low photon energy also limits doses to hospital personnel and others when compared to temporary implants with iridium-192 or permanent implants with gold-198 (CL89, RU92). Although iodine-125 implants are most commonly used to treat cancer of the prostate (DE86, FU91, HE82, MO88, PR92, WH88), they have also been used on a very limited basis for brain tumors (AG92, OS92, SC92), carcinomas of the pancreas (MO92), non-oat cell lung carcinomas (FL92), breast cancers (RU92), and tumors of the head, neck, and eye.

Palladium-103 seeds were developed for use in brachytherapy to reduce some of the problems associated with iodine-125. Its average photon energy of $21 \mathrm{keV}$ is lower than iodine-125, but, given its shorter 17 day half-life, it has a higher initial dose rate. Recently, palladium-103 seeds have been developed with the same physical parameters as iodine- 125 seeds to ensure compatibility with the brachytherapy tubes and templates used for iodine implantation (ME90).

Ytterbium-169 has been hailed as a replacement for iodine-125 in brachytherapy. Compared to iodine-125 and palladium-103, it has a slightly higher initial dose rate, and its average $93 \mathrm{keV}$ beta energy allows for a more favorable dose distribution and negligible tissue self-attenuation (PO90). However, its use as a permanent implant is nominal due to the presence of a small (less 
than 3 percent) average photon peak at $300 \mathrm{keV}$, that can significantly impact radiation doses to individuals in proximity to the patient.

Gold-198 implants have been used in a few instances of prostate cancer (CA88, FR88). The potential advantage of delivering a high dose within a relatively short time, however, is offset by its energetic gamma emissions, which has caused its use in recent years to fall into disfavor and be used only rarely (CA87).

A thorough search of the literature and personal communications with several prominent members of the medical and scientific community (see Acknowledgements) indicates that there is no published data available to quantify the annual number of cancer patients receiving permanent implants. However, the scientific literature and consensus opinion among the experts identified in the acknowledgments to this report does support the following:

1. permanent implants are currently considered an appropriate treatment for only a few sites of solid tumors;

2. among the cancer sites for which permanent implants are currently employed, prostate cancer represents the overwhelming majority;

3. among the 132,000 annual new cases of prostate cancer (ACS93), only a small fraction is treated with permanent implants; and,

4. for the purposes of this analysis, implants involving gold-198 (largely discontinued) and ytterbium-169 (isolated use only) may be ignored.

In the absence of documented clinical data, information was sought from the implant vendors on numbers of administrations and typical activities of radioactive material used per administration. Currently, there are only three vendor sources. Vendor supplied data suggests that approximately 2,000 implants involving iodine-125 are performed annually, at activities ranging from 1,110 to 1,850 megabecquerels (30 to 50 millicuries). For palladium-103, approximately 1,500 implants are performed annually, at activities ranging from 2,775 to 4,625 megabecquerels ( 75 to 125 millicuries).

\subsubsection{Summary of Therapeutic Administrations}

Table 4.4 summarizes the range of the activities of gamma-emitting radionuclides used in therapeutic administrations and the estimates of the numbers of each therapy performed annually.

\subsection{Assessment of Doses to Individuals Exposed to Patients Administered Radioactive Materials}

To identify the potential impacts associated with each of the alternatives, it is necessary to know the magnitude of doses that could be received by an individual exposed to a patient who has been administered radioactive materials. While exposure can occur via any of the elimination pathways by which radionuclides are removed from the body (e.g., exhalation, feces, saliva, sweat, urine, and possibly vomit), experience indicates that for iodine- 131 and other gamma emitters, these pathways will generally be insignificant in relation to the doses that can result from exposure to the direct gamma radiation from the patient, with the exception of intake from the milk in breast-feeding infants. This section of the report assesses the external and internal doses to individuals, including a breast-feeding infant, exposed to patients who have been administered radioactive materials.

\subsubsection{Methodology for Calculating External Gamma Dose}

The methodology for calculating the external gamma dose from exposure to the released patient is also described in the associated regulatory guide for the final rule (NRC97). The methodology is based on the one employed in the National Council on Radiation Protection and Measurements (NCRP) Report No. 37, "Precautions in the Management of Patients Who Have Received Therapeutic Amounts of Radionuclides" (NCRP70). 
Table 4.4 Number of Annual Therapeutic Administrations in the United States (significant gamma-emitting radionuclides only)

\begin{tabular}{|c|c|c|c|c|}
\hline $\begin{array}{l}\text { Therapeutic } \\
\text { Procedure }\end{array}$ & $\begin{array}{c}\text { Radionuclide } \\
\text { Employed }\end{array}$ & \multicolumn{2}{|c|}{$\begin{array}{l}\text { Range of Activities } \\
\text { Administered }\end{array}$} & $\begin{array}{l}\text { Estimated No. of } \\
\text { Administrations } \\
\text { (per year) }\end{array}$ \\
\hline $\begin{array}{l}\text { Thyroid Ablation and } \\
\text { Hyperthyroidism }\end{array}$ & $\mathrm{I}-131$ & $370-2,220^{*}$ & $(10-60)$ & 50,000 \\
\hline Thyroid Cancer & $\mathrm{I}-131$ & $1,850-11,100^{\ddagger}$ & $(50-300)$ & 10,000 \\
\hline Permanent Implant & I-125 & $1,110-1,850^{t}$ & $(30-50)$ & 2,000 \\
\hline Permanent Implant & Pd-103 & $2,775-4,625^{\dagger}$ & $(75-125)$ & 1,500 \\
\hline Total & & & & 63,500 \\
\hline
\end{tabular}

* Based on personal communications, F. A. Mettler, March 1993 and M. Pollycove, January 1996.

* Based on personal communications, F. A. Mettler and K.L. Miller, March 1993.

t Based on information supplied by implant vendors, August 1993.

To calculate the dose to total decay $D(\infty)$, the regulatory guide uses the following equations. For radionuclides with a half-life greater than 1 day

$$
D(\infty)=\frac{34.6 \Gamma Q_{o} T_{p}(0.25)}{(100 \mathrm{~cm})^{2}},
$$

and for radionuclides with a half-life less than or equal to 1 day

$$
D(\infty)=\frac{34.6 \Gamma Q_{0} T_{p}}{(100 \mathrm{~cm})^{2}}
$$

where $\Gamma=$ exposure rate constant for a point source, $\mathrm{R} / \mathrm{mCi}-\mathrm{h}$ at $1 \mathrm{~cm}$,

$Q_{0}=$ initial activity of the point source in millicuries, at the time of release,

$T_{p}=$ physical half-life in days.

\subsubsection{Occupancy Factor}

Equation 1 assumes, for radionuclides with half-lives greater than 1 day, that the individual likely to receive the highest dose from exposure to the patient would receive a dose of 25 percent of the dose to total decay ( 0.25 in Equation 1$)$ at a distance of 100 centimeters ( 1 meter). For radionuclides with half-lives no greater than 1 day, the factor 1.0 is used in Equation 2 because the assumption that the time that individuals will spend near the patient will be limited is not valid when most of the dose is delivered in a relatively short time.

Doses among individuals who may come in contact with a released patient are highly variable and reflect the crucial, but difficult to define, parameters of time, distance, and shielding. Based on time and distance considerations, it is reasonable to conclude that for the overwhelming majority of released patients, the maximally exposed individual is likely to be the primary careprovider, a family member, or any other individual who spends significant time close to the patient.

Based on time, distance, and shielding factors, which describe normal lifestyles of the United States population, it is highly unlikely that doses equal to spending 100 percent of time at a distance of 1 meter from a patient would result to any individual including a patient's spouse. As a standard medical practice, patients undergoing therapeutic treatments with radiopharmaceuticals are given firm instructions, both verbally and in writing, regarding basic principles on how to minimize doses to other individuals.

Given all considerations, a reasonable estimate of the maximal likely dose to an individual exposed to a patient is 25 percent of the dose to total decay at a distance of 1 meter (except for the short-lived radionuclides). The selection of an occupancy factor of 25 percent at 1 meter for estimating maximal likely exposure is based on the authors' professional judgment of time-distance combinations that are believed likely to occur 
Table 4.5 Family Doses from Patients Treated with Iodine-131 for Thyroid Carcinoma

\begin{tabular}{ccccc} 
Total & $\begin{array}{c}\text { Activity } \\
\text { Administered } \\
(\mathbf{m C i})\end{array}$ & $\begin{array}{c}\text { Body Burden } \\
\text { at Time of } \\
\text { Discharge } \\
\text { (mCi) }\end{array}$ & $\begin{array}{c}\text { Measured } \\
\text { Doses to } \\
\text { Family } \\
\text { Members } \\
\text { (mrem) }\end{array}$ & $\begin{array}{c}\text { Predicted } \\
\text { Dose Based on } \\
\text { Occupancy Factor of } \\
\text { 25\% at 1 meter } \\
\text { (mrem) }\end{array}$ \\
\hline 1 & 210 & 25.2 & $80,70,30$ & 386 \\
2 & 311 & 26.4 & $50,20,20$ & 404 \\
3 & 209 & 18.4 & 80,40 & 282 \\
\hline
\end{tabular}

Source: HA74.

when instructions to minimize time spent close to the patient are given.

The occupancy factor of 0.25 at 1 meter is also supported by empirical data. Harbert and Wells (HA74) monitored the external dose of 8 family members of 3 patients treated for thyroid carcinoma using iodine-131. All doses to family members were far below 5 millisieverts ( $0.5 \mathrm{rem})$ as shown in Table 4.5. The last column of Table 4.5 provides dose estimates based on the occupancy factor of 25 percent at 1 meter in Equation 1. The actual doses are far below the calculated doses for an occupancy factor of 25 percent at 1 meter, indicating that the model generally provides a conservative estimate of the dose.

Harbert and Wells (HA74) also measured the external doses to 11 family members of seven hyperthyroid patients. All doses to family members were far below 5 millisieverts $(0.5 \mathrm{rem})$. In each case, the measured doses were at least a factor of 10 below the doses predicted by Equation 1 using an occupancy factor of 0.25 at 1 meter.

Jacobson et al. (JA78) measured the external doses to 10 family members of 7 iodine therapy patients. In each case except one, the external dose to the family member was below that predicted by Equation 1 using an occupancy factor of 0.25 at 1 meter and well below 5 millisieverts $(0.5 \mathrm{rem})$. In the case of the exception, the family went on an extended vacation spending much of the time together in an automobile. This demonstrates that if reasonable efforts to maintain distance are not made doses can be higher than predicted by Equation 1.

Buchan and Brindle (BU71) monitored the doses of 54 family members of patients who underwent iodine therapy for hyperthyroidism. This study is interesting because no instructions on minimizing dose were given. Thus, the results can be taken to represent the doses that would be received if no instructions were given or if instructions were totally disregarded. The highest measured dose to a family member was 2.7 millisieverts $(0.27 \mathrm{rem})$, much below the 5-millisievert (0.5-rem) limit. The effective occupancy factor at 1 meter was less than or equal to 0.25 in 45 of the 54 cases ( 83 percent). Thus, even in the complete absence of instructions, the occupancy factor at 1 meter was usually less than 0.25 .

In conclusion, both empirical measurements and professional judgement support an occupancy factor of 0.25 at 1 meter as a generally conservative value. Using this value in Equation 1 should generally overpredict the dose even if instructions are not given or are not strictly followed. However, higher occupancy factors are certainly possible in situations where instructions are disregarded and are not considered a problem for this rulemaking. The NRC's rulemaking based on Alternative 3 provides an adequate level of protection with a significant margin of safety for those families that make a reasonable effort to follow the instructions. The NRC considers that to be sufficient. 


\subsubsection{Exposure Rate Constant}

The exposure rate constant $\Gamma$ expresses the dose rate per hour at 1 centimeter in air for a

37-megabecquerel (1-millicurie) point source of a given radionuclide. The exposure rate constants and the physical half-lives of radionuclides used in medicine are shown in Table A.1 of Appendix A.

For permanent implants, a significant reduction in the dose and dose rate occurs from the shielding effects of the source capsule. For iodine-125 and palladium-103 implants, the dose to total decay at 1 meter was calculated using an exposure rate constant corrected for capsule shielding as shown in Table A.1 of Appendix A. The physical characteristics of other radionuclides used in permanent implants (e.g., gold-198 and ytterbium-169) are also given in Appendix A.

\subsubsection{Biological Retention and Elimination}

\section{Effective Half-Life}

A licensee may replace $T_{p}$ in Equations (1) and (2) with the effective half-life $T_{\text {eff }}$ of the radioactive material to demonstrate compliance with the dose limit in the revised 10 CFR 35.75. $T_{e f f}$ is characterized by $T_{p}$ and the biological half-life $T_{b}$ of the radionuclide (which accounts for the biological retention and elimination of the radionuclide from the patient's body) according to the equation

$$
T_{e f f}=\frac{T_{p} \times T_{b}}{T_{p}+T_{b}}
$$

Under the final rule a licensee could authorize release on a case-by-case basis based on the biological half-life rather than only the physical half-life of the radiopharmaceutical.

\section{Biological Retention and Elimination of Iodine-131}

For iodine-131, biological retention and elimination are characterized by the fractional amounts that reside in the thyroid (i.e., thyroidal component) and in the rest of the body (i.e., extrathyroidal component). Each component has a specific fractional uptake and biological half-life, both of which are dependent upon the physical condition of the patient. Table 4.6 provides the uptake fraction and biological half-life for each component with respect to patients being treated for hyperthyroidism (and thyroid ablation) and thyroid cancer. The extrathyroidal and thyroidal uptake fractions for thyroid cancer assume surgical removal of the thyroid gland prior to iodine-131 therapy.

To determine the total dose to an individual exposed to a patient administered iodine-131, considering biological retention and elimination by the patient, Equation 1 must be split into two terms that separately represent the dose contribution from the thyroidal and extrathyroidal components. The following equation was used to calculate the total dose to complete decay assuming an occupancy factor of 0.25 at 1 meter:

$$
D(\infty)=\frac{34.6 \Gamma Q_{o} T_{1 \text { leff }} F_{1}(0.25)}{(100 \mathrm{~cm})^{2}}+
$$

$$
\frac{34.6 \Gamma Q_{o} T_{2 e f f} F_{2}(0.25)}{(100 \mathrm{~cm})^{2}}
$$

where $T_{\text {leff }}=$ effective half-life of the extrathyroidal component in days (based on the biological half-life $T_{b 1}$ of the thyroidal component),

$$
\begin{aligned}
F_{1}= & \text { extrathyroidal uptake fraction, } \\
T_{2 e f f}= & \begin{array}{l}
\text { effective half-life of the thyroidal } \\
\text { component in days (based on the } \\
\text { on the biological half-life } T_{b 2} \text { of the } \\
\text { thyroidal component), }
\end{array} \\
F_{2}= & \text { thyroidal uptake fraction, } \\
\Gamma= & \text { exposure rate constant for a point } \\
& \text { source, } \mathrm{R} / \mathrm{mC} \text {-h at } 1 \mathrm{~cm}, \\
Q_{0}= & \text { initial activity of the radionuclide in } \\
& \text { millicuries, at the time of release. }
\end{aligned}
$$

This equation is only valid if the release occurs at the time of administration. 
Table 4.6 Iodine-131 Biological Retention and Elimination Parameters for Hyperthyroidism, Thyroid Ablation, and Thyroid Cancer*

\begin{tabular}{|c|c|c|c|c|}
\hline \multirow[b]{2}{*}{ Disease } & \multicolumn{2}{|c|}{$\begin{array}{c}\text { Extrathyroidal } \\
\text { Component }\end{array}$} & \multicolumn{2}{|c|}{$\begin{array}{l}\text { Thyroidal } \\
\text { Component }\end{array}$} \\
\hline & $\begin{array}{c}\text { Uptake } \\
\text { Fraction } \\
F_{1} \\
\end{array}$ & $\begin{array}{c}\text { Biological } \\
\text { Half-Life } \\
T_{b 1} \text { (days) } \\
\end{array}$ & $\begin{array}{c}\text { Uptake } \\
\text { Fraction } \\
F_{2} \\
\end{array}$ & $\begin{array}{c}\text { Biological } \\
\text { Half-Life } \\
T_{b 2} \text { (days) }\end{array}$ \\
\hline Hyperthyroidism and & 0.10 & 0.33 & 0.90 & 10 \\
\hline Thyroid Ablation & 0.20 & 0.33 & 0.80 & 15 \\
\hline & 0.30 & 0.33 & 0.70 & 20 \\
\hline & 0.40 & 0.33 & 0.60 & 20 \\
\hline & 0.50 & 0.33 & 0.50 & 25 \\
\hline & 0.60 & 0.33 & 0.40 & 40 \\
\hline & 0.70 & 0.33 & 0.30 & 65 \\
\hline Thyroid Cancer & 0.95 & 0.33 & 0.05 & 80 \\
\hline
\end{tabular}

* Data taken from ICRP Publications 30 (ICRP78), 53 (ICRP87), and 56 (ICRP89), and personal communication, M. Pollycove, March 1996, based on his clinical experience.

\subsubsection{Tissue Shielding for Permanent Implants}

In addition to the shielding effects of the source capsule (see 4.2.1.2 Exposure Rate Constant), a significant reduction in the dose and dose rate also occurs from the tissue surrounding the implant. For a prostate implant, tissues that serve to reduce photon flux about the patient include the soft and bone tissues of the thighs, pelvis, buttocks, abdomen, etc. The linear attenuation coefficient and corresponding soft tissue half-value layer for the $27 \mathrm{keV}$ photon of iodine- 125 are $0.387 \mathrm{~cm}^{-1}$ and $1.8 \mathrm{~cm}$, and for the $21 \mathrm{keV}$ photon of palladium-103, $0.770 \mathrm{~cm}^{-1}$ and $0.9 \mathrm{~cm}$, respectively (JOH83).

To assess the impact of tissue shielding by the patient, the medical physicist of the Memorial Sloan Kettering Cancer Center was consulted (personal communication, J. St. Germain, March 1993). Based on empirical assessment involving patients with prostate implants, tissue shielding for iodine- 125 is likely to exceed 5 or more half-value layers (HVLs), which would reduce the dose and dose rate by a factor of at least 32 . For palladium-103 implants, in which the HVL in tissue is less than 1 centimeter, the shielding afforded by the patient's tissue is even more extensive. For other implants involving the lungs, brain, pancreas, etc., tissue shielding values of similar magnitude can be assumed for an adult male and female. However, for certain implants involving primary cancers of the neck and head, overlying tissues may provide less than 5 HVLs of attenuation. In such instances, it is standard practice to provide the patient with a small portable "shield" which effectively attenuates all emissions (personal communications, C. Jacobs, August 1993, and R. Nath, J. St. Germain and K. Suphanpharian, March 1993). A shield consists of a vinyl sheet impregnated with lead and molded to fit the anatomical surface over the implant.

For the purposes of this analysis, implants will be evaluated considering shielding by tissue equivalent to 5 half-value layers.

\subsubsection{Assessment of Internal Exposure}

\subsubsection{Internal Exposure Pathways}

Upon oral administration or direct injection into the circulating blood, the radiopharmaceutical undergoes the normal processes of absorption, distribution, and excretion. Removal of radionuclides from the patient's body may follow the pathways of breast milk, exhaled air, feces, saliva, sweat, urine and vomitus. 
Breast Milk. Radionuclide excretion via the mammary gland constitutes a potential exposure pathway to the breast-fed infant. This can be a very important pathway after the administration of radioiodines. Relatively small administrations of radioiodine to a breast-feeding women can cause very large doses to the thyroid of the infant. Cessation of breast-feeding for iodine administrations avoids the potential for thyroid ablation in the infant.

Exhaled Air. Exhalation is the principal pathway for the elimination of radioactive gases such as xenon-133, which is used for lung ventilation tests. Through passive diffusion, unbound iodide in the circulating blood may also be exhaled.

Feces. Radiopharmaceuticals retained or catabolized by the liver may be secreted into the gastrointestinal lumen via the bile. Biliary secretion of a radionuclide may be followed by intestinal reabsorption.

Saliva. Salivary excretion of radionuclides is also proportional to the unbound or diffusible fraction in the plasma. However, salivary excretion is seldom an important elimination route, since nearly all saliva is swallowed rather than expectorated.

Sweat. Radionuclides present in the extracellular fluid will tend to be excreted in the sweat in accordance with the fraction that is unbound in the plasma.

Urine. Radionuclide excretion in the urine is the dominant and almost universal elimination pathway.

Vomitus. The occurrence of vomiting is not related to the administration of iodine-131 or any other radiopharmaceutical (personal communication, M. Pollycove, August 1995). Furthermore, vomiting is seldom an important elimination route, since orally administered radiopharmaceuticals such as iodine-131 are rapidly absorbed, within a half hour, by the gastrointestinal system. However, a significant portion of the administered radionuclide could be excreted if vomiting occurs immediately following the administration. In this case the patient typically would not have been released, and the licensee would be able to limit exposure and clean up contamination.

\subsubsection{Measurements of Internal Exposure}

The potential for contamination by patients treated with radioiodine which may serve as a source for internal exposures to others have been assessed for various excreta pathways (BL71, MA73, N180). Maximum excretion rates are observed shortly after an administered dose. Excretion rates decline rapidly thereafter due to renal clearance and thyroidal uptake. Almost all the excreted activity is excreted in the urine. Contamination through urinary excretion may be readily controlled by cautious but reasonable hygiene practices.

In a thorough study of two patients treated for thyroid carcinomas, Nishizawa, et al. (NI80) observed maximum excretion rates of iodine in exhalation, perspiration, and saliva of $3.2 \times 10^{-6} / \mathrm{hr}, 2.4 \times 10^{-6} / \mathrm{hr}$, and $6.3 \times 10^{-3} / \mathrm{hr}$ of the administered dose, respectively. Thus, the amounts in exhalation and perspiration were very small. The amount in saliva is larger, but transfer of saliva to other people is likely to be limited.

A British study (BU70) estimated thyroid radioiodine activity in 39 subjects who, as family members, were associated with patients treated for hyperthyroidism. Administered quantities ranged from 148 to 740 megabecquerels (4 to 20 millicuries) per patient. Of the 39 patients, 28 were instructed to take precautionary measures to minimize exposure to family members. Eleven patients volunteered to disregard special precautions against contamination and minimizing spousal and family exposure. On the basis of one measurement per family, subject thyroid burdens ranged from less than 37 to 1,110 becquerels ( 1 to 30 nanocuries) with an average of 259 becquerels (7 nanocuries). Thus, the uptake of radioiodine by family members was only about 1 millionth of the administered quantity, and the dose from the uptake was less than 0.01 millisievert ( 1 millirem) committed effective dose equivalent. This internal dose is negligible compared to the external dose. The authors concluded that contamination is not important and "except where young children are involved, precautions to minimize contamination should be abandoned."

In a 1978 study by Jacobson, et al. (JA78), seven families were studied in which one family member had been treated with iodine-131 doses ranging from 296 to 5,500 megabecquerels (8 to 
150 millicuries). Non-patient family members were assessed for external exposures by means of thermoluminescent dosimeters (TLDs) worn at the wrist for the full duration of exposure. Internal exposure (i.e., thyroid burden) was determined at discrete time intervals by means of a pair of 30-inch NaI crystals. Although all family members proximal to the patient had measurable thyroid burdens, dose estimates in nearly all cases indicate that internal committed effective dose equivalents were always less than 10 percent of the 5-millisievert (0.5-rem) dose limit, even when no precautions were taken, and the external dose substantially exceeded the internal dose.

The investigators also concluded that it " ... appears certain from our study of these subjects that for spouses, there is a relation between thyroid activity and intimacy. Of the 12 husbands and wives questioned, ... none were willing to adjust living habits with their spouses because of the radiation therapy. Most, however, are concerned for their children and are willing to listen to suggestions which minimize exposure to their children." While the authors are vague about what they mean by "adjust living habits," it appears that couples are often unwilling to abstain from brief periods of close intimate contact for prolonged periods of time. This should not be a problem because the brief times will be too short to add significant external dose and transfer of contamination is not a significant contributor to internal dose.

Thus, the studies on internal exposures suggest that internal doses from intake of contamination are likely to be much smaller than doses from external radiation and much smaller than the public dose limit. Therefore, internal exposures will not be considered in this analysis other than for the breast-feeding infant.

\subsubsection{Estimate of Maximum Likely Doses to Individuals Exposed to Patients}

Assessments were made of the doses that could result from exposure to a patient treated with each of the radionuclides used.

\subsubsection{Diagnostic Procedures}

The results of the dose calculations for diagnostic procedures are summarized in Table 4.7.
Table 4.7 indicates that, except for some procedures using iodine-131 to detect thyroid cancer, none of the other diagnostic procedures currently being performed have the potential to deliver a 1 millisievert $(0.1 \mathrm{rem})$ dose to an individual exposed to a patient. However, in the case of iodine-131, the effective half-life of the extrathyroidal component is much shorter than the physical-life used to calculate doses. Therefore, the dose would be much lower than the value shown in Table 4.7. Since the doses in all cases are much below 1 millisievert (0.1 rem), diagnostic procedures will not be considered any further in this analysis.

\subsubsection{Therapeutic Procedures}

The results of the dose calculations for therapeutic procedures using the physical and effective half-lives (as applicable) are summarized in Table 4.8. All calculations assume an occupancy factor of 25 percent at a distance of 1 meter and immediate release of the patient by the licensee (i.e., no hospitalization). For hyperthyroidism (and thyroid ablation), doses based on effective half-life have been calculated using the four thyroidal uptake fractions that characterize the majority of patients with this disease. Table 4.8 indicates that the model considering biological retention and elimination provides dose estimates that are significantly less than the model that considers physical half-life only.

For the purposes of this analysis, the dose estimates for iodine- 131 based on the biological model will be used because this model more closely reflects the behavior of iodine-131 in humans. For permanent implants, biological modeling does not apply. In this case, this analysis uses the dose estimates based on the physical half-life. Only the therapies involving radioiodine would be affected by any of the alternatives under consideration.

\subsubsection{Assessment of Doses to Breast- Feeding Infants}

If a radiopharmaceutical is administered to a woman who is breast-feeding an infant, a fraction of the quantity administered may be deposited in the breast milk and may be transferred to the infant. In considering the dose to the individual likely to receive the highest dose from exposure to 
Table 4.7 Maximum Likely Doses to Total Decay to Exposed Individuals from Diagnostic Procedures

\begin{tabular}{lcccc}
\hline $\begin{array}{l}\text { Examination Type } \\
\text { (Radiopharmaceutical) }\end{array}$ & \multicolumn{2}{c}{$\begin{array}{c}\text { Activity per } \\
\text { Examination* }\end{array}$} & \multicolumn{2}{c}{$\begin{array}{c}\text { Gamma Dose } \\
\text { (mSv) }\end{array}$} \\
\hline (rem)
\end{tabular}

* The activity is the typical quantity administered per examination (see Table 4.2). The maximum diagnostic activity of I-131 is shown because it yields gamma doses exceeding 1 millisievert ( 0.1 rem).

+ Calculations assume no biological elimination, no attenuation of gamma rays in air or body of patient, and occupancy factors of 100 percent at a distance of 1 meter for Tc-99m and 25 percent at a distance of 1 meter for I-131 and TI-201. 
Table 4.8 Maximum Likely Doses to Total Decay to Exposed Individuals from Therapeutic Procedures Assuming No Hospitalization

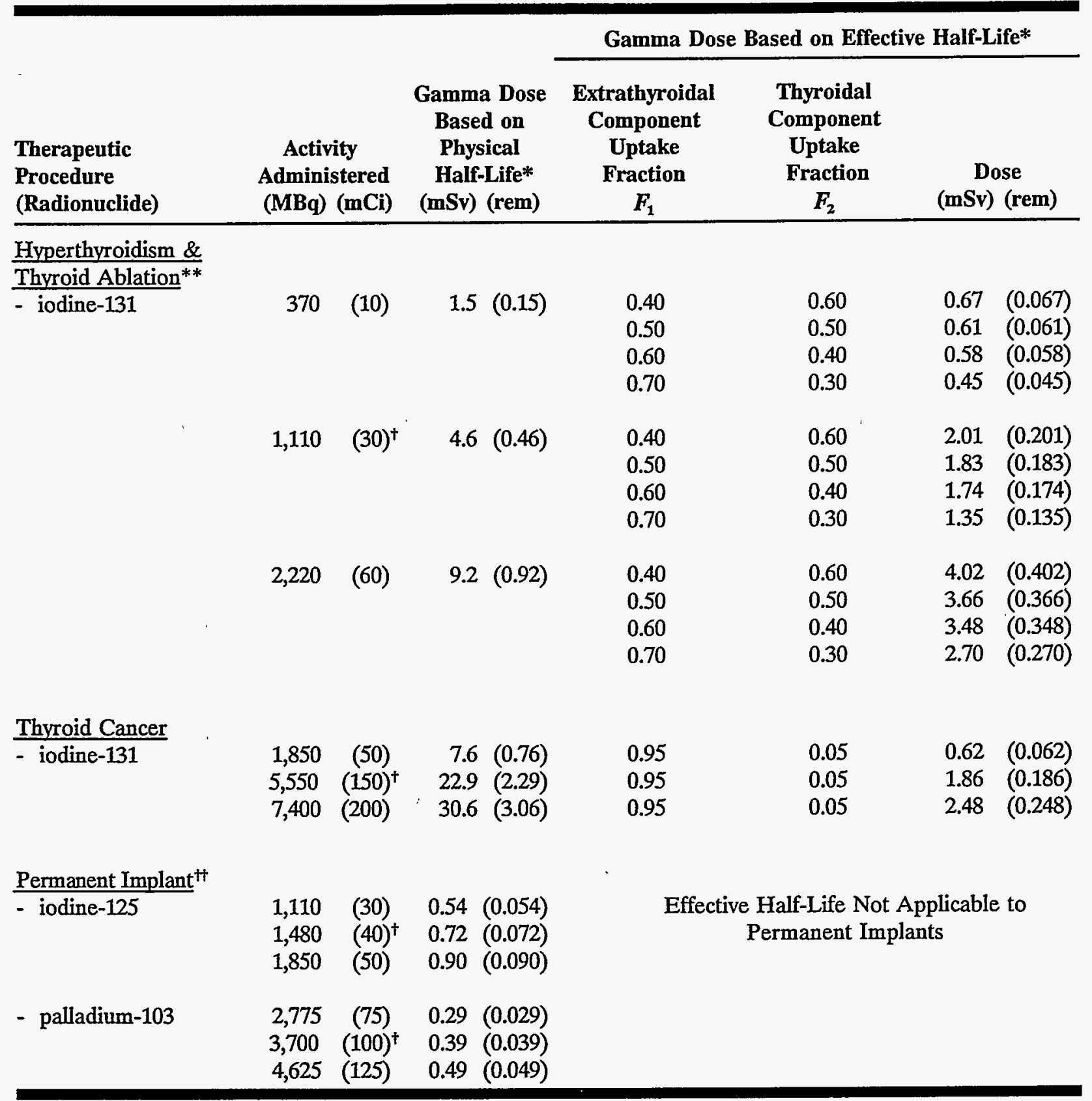

* Maximum likely dose based on an occupancy factor of 25 percent at a distance of 1 meter.

** Doses have been calculated for the four thyroidal uptake fractions that characterize the majority of patients treated.

Typical activity administered.

It These dose values account for the 5 HVLs of tissue shielding by the patient and, therefore, are equal to the point source dose in air divided by 32 . 
a patient who has been administered a radiopharmaceutical, it is necessary to consider both the internal and external dose to the infant from breast-feeding.

\subsubsection{Internal Dose}

The potential internal dose to the breast-feeding infant was calculated for the maximum normally administered quantities of commonly used diagnostic and therapeutic radiopharmaceuticals. The results of the calculations are shown in Appendix B.

The doses can be represented as a range where the range covers the minimum and the maximum transfer of radioactive material from published data. The range is due to individual variability and measurement variability as indicated by concentrations measured in breast milk. Doses were calculated for newborn and one-year-old infants. Since the doses for newborn infants are higher, those doses were used in the analysis. The internal dose ranges for commonly used radiopharmaceuticals assuming no interruption of breast-feeding are shown in Column 3 of Table B.5 (see Appendix B). The radionuclides in the table that are not regulated by the NRC (e.g., Ga-67) are omitted from further consideration in this analysis.

\subsubsection{External Dose}

To determine a realistic estimate of the external dose to total decay to the infant during breast feeding, an occupancy factor must be selected that specifically reflects the variables involved. It can be assumed that the average infant feeds for a period lasting 30 minutes every 3 hours, resulting in an occupancy factor of 16 percent. Breastfeeding requires close contact, the analysis uses 20 centimeters as the distance between the infant and the source. Also, since only the physical half-life is considered, the analysis is conservative. The results are shown in Column 4 of Table B.5 assuming no interruption in breast-feeding.

The final rule requires that instructions, including written instructions, on maintaining the doses to other individuals as low as is reasonably achievable be given to the released patient if the dose to another individual is likely to exceed
1 millisievert $(0.1 \mathrm{rem})$. If the sum of the doses in Columns 3 and 4 of Table B.5 (i.e, internal (maximum value) and external doses, respectively) for a radiopharmaceutical exceeds 1 millisievert ( $0.1 \mathrm{rem})$, then instructions would be required.

\subsubsection{Special Considerations for Iodine-131 Sodium Iodide}

There are specific issues associated with the administration of iodine-131 sodium iodide in that following both diagnostic and therapeutic administrations, the dose to a breast-feeding child could exceed 5 millisieverts $(0.5 \mathrm{rem})$ if there was no interruption of breast-feeding. In particular, if the woman does not cease breast-feeding after administration of millicurie quantities of iodine-131 sodium iodide, the internal dose to the breast-feeding infant could be large enough to cause the infant's thyroid to be severely damaged, resulting in hypothyroidism. If hypothyroidism were undiagnosed in very young children, severe mental retardation may occur. However, if the patient was provided instructions to discontinue breast-feeding, as well as being advised of the consequences of not following the instructions, the NRC believes that the probability of a woman failing to cease breast-feeding after being administered iodine-131 sodium iodide is small. For example, in 1990 an administered dosage of 185 megabecquerels (5 millicuries) of iodine- 131 sodium iodide to a patient resulted in her breast-fed infant receiving an unintended radiation dose of 300 grays $(30,000$ rads) to the infant's thyroid gland. This dose would result in ablation of the infant's thyroid. This situation was recognized in 2 days, which allowed prompt action to be taken thereby reducing potential consequences such as mental retardation. The NRC is aware of two other cases that occurred during 1991 and 1995. In each of these cases, there was a breakdown in communications, rather than lack of intent to prevent breast-feeding. This rule might therefore be expected to provide a benefit by reducing the probability of a woman breast-feeding an infant after administration of large quantities of iodine- 131 .

In some cases, instructions to interrupt or discontinue breast-feeding may not be effectively communicated. To deal with this issue, the NRC considered a range of options which varied from 
maintaining the status quo to the extreme option of confining a woman for a period of time after administration of millicurie quantities of iodine-131 sodium iodide to ensure her milk production has stopped. Included within this range of options was the option to enhance communication between the licensee and woman regarding instructions to interrupt or discontinue breast-feeding before the woman is released from the hospital. It is estimated that approximately $400^{*}$ breast-feeding women could be administered millicurie amounts of iodine-131 sodium iodide each year for diagnosis and treatment of thyroid disease.

The option of maintaining the status quo does not provide the assurance that instructions will be provided to a breast-feeding woman and could still allow for a breakdown in communications. As indicated above, the NRC is aware of three cases of unintended exposure to a breast-feeding child during the last five years. There would be no costs associated with this option.

At the other end of the range, for the extreme option, a woman would remain in the hospital until she stopped producing milk. However, this option would result in psychological impacts to both the woman and breast-feeding infant, by requiring them to be physically separated for some period of time, which are not quantified by this analysis. This option was also considered to be impractical as it would be difficult for a medical institution to separate a woman and breast-feeding child. That is, this option does not prevent the breast-fed child from being brought into the patient's room, nor does it address the situation of the patient releasing herself against medical advice. Also, to require cessation of breast-feeding after administration of iodine-131 sodium iodide by hospital retention, or prior to administration (to avoid hospital retention), directly impacts the practice of medicine, since it would in effect dictate when a treatment could be given. It is estimated that each woman would remain in the hospital for an average of 7 days at a cost of $\$ 1,000$ per day. The estimated annual

\footnotetext{
* The number of breast-feeding women was determined as follows: 60,000 patients administered millicurie quantities of iodine-131 sodium iodide $x 0.135$ child bearing age $x 0.05$ breast-feeding $=405$ patients administered millicuries of iodine who could be breast-feeding.
}

cost for the extreme option is $400 \times 7 \times \$ 1,000$ $=\$ 2.8$ million. In addition, there would be associated costs for providing women with instructions and information as to the need for hospital retention. The circumstances of a woman choosing to ignore the warning that breast-feeding would cause significant harm to the infant and to continue to breast-feed are considered to be very rare. As stated above, NRC is not aware of any instance where this has occurred. Therefore, the extreme option was not selected because of the negative psychological impact to both the woman and infant, as well as the high annual dollar cost.

Regarding the preferred option to enhance communication, although instructions to keep doses to household members and the public as low as is reasonably achievable are currently required for radiopharmaceutical therapy in 10 CFR 35.315(a)(6), there is no requirement specific to the dose from breast-feeding. To enhance communications, amended 10 CFR 35.75(b) will require licensees to provide guidance on the interruption or discontinuation of breast-feeding and information on the rationale for following the guidance. Compliance with the regulation provides NRC with confidence that the licensee will give the instructions to breast-feeding women and it is expected that almost all women will follow instructions to interrupt or discontinue breast-feeding to protect their children from potentially harmful effects. The NRC is not aware of any instances where instructions were given to the woman but she ignored the warning and continued breast-feeding a child. Since the estimated costs per patient for providing instructions and recordkeeping are $\$ 22$ and $\$ 17$, respectively (see 4.3.1.1 Estimates of the Direct Costs of Patient Retention), the estimated costs for this option would be about $\$ 16,000$ per year. Therefore, the option to enhance communication is selected as the preferred option. It should be noted that since the extreme option was not selected for administrations of millicurie quantities, then it would follow that for microcurie quantities it would not be cost effective.

\subsubsection{Summary of Doses to Breast-Feeding Infants}

The dose to the breast-feeding infant can be controlled by giving the woman instructions, as required by the revised 10 CFR 35.75, to discontinue or to interrupt breast-feeding as 
appropriate. The decision to require instructions as shown in Column 5 of Table B.5 is based on both the external and internal dose to the nursing infant. It can be seen from Column 4 that for some radiopharmaceuticals the external dose from breast-feeding can be a significant part of the total dose. The duration of the interruption shown in Column 6 is selected to reduce the maximum dose to a newborn infant to less than 1 millisievert (0.1 rem).

The actual doses that would be received by most infants for the recommended interruption periods shown should be a small fraction of 1 millisievert $(0.1 \mathrm{rem})$ due to the conservatism of the analysis. The conservative factors are based on: (1) the maximum measured level of activity in breast milk, (2) the longest biological half-life, and (3) the lowest body weight (i.e., the newborn). These factors are explained in Appendix B.

\subsubsection{Collective Dose}

To evaluate each alternative, it is also necessary to estimate not only the dose to the maximally exposed individual, but also the collective dose to other individuals who may be exposed to patients administered radioactive materials. To calculate precisely the collective dose that would be received under any of the alternatives would require detailed information of a highly diverse group of patients relative to lifestyles, living arrangements, work environments, social activities, etc. This information does not exist and is essentially impossible to precisely determine. In place of a precise estimate we have made a rough estimate of the collective dose per therapeutic procedure which we believe is adequate for the purposes of this rulemaking.

\subsubsection{Collective Dose to Individuals}

Based on considerations of the written instructions provided patients, the demographics of the patient population (see Table 4.3), and time, distance, and shielding factors, we estimate that the collective dose per procedure is 3 times the maximal dose (i.e., the dose to the most exposed individual). This 3 times factor could occur in the following manner, based upon intuitive assumptions about a typical family and friends. In addition to the person receiving the maximal dose, who is likely to be the primary care-provider, there could be two other people who will average about half as much time near the patient. There might also be about four other people who will average about a quarter as much time near the patient as the maximally exposed individual. The sum of the collective dose to all these people is 3 times the dose to the maximally exposed individual. This situation could represent a typical family and friends. Of course some patients will spend more time near other people, but other patients will spend less. A collective dose of 3 times the dose to the maximally exposed individual is thus a reasonable average representation.

Finally, as data are not available on the distribution of the quantities of radionuclides administered for each therapeutic procedure, the estimates of collective dose for each alternative are based on the typical activities used within the ranges of activities administered and the maximum activity used for thyroid ablation.

By using the results from Table 4.8 (based on the biological model described by Equation 4) Tables 4.9, 4.10 , and 4.11 present the estimates of the collective doses for Alternatives 1, 2, and 3, respectively, for therapeutic administrations that could be affected by the choice of alternative. For the typical administration of iodine-131 for thyroid ablation, this analysis uses 1.73 millisieverts $(0.173 \mathrm{rem})$ (the maximum likely dose to an individual exposed to a patient assuming no hospitalization) as the basis for estimating the collective doses. This value is the average of the four doses calculated for the thyroidal uptake fractions that characterize the majority of patients undergoing thyroid ablation. In a similar manner, the dose from the maximum quantity administered (2,220 megabecquerels (60 millicuries)), was determined to be 3.47 millisieverts $(0.347 \mathrm{rem})$. For thyroid cancer, this analysis uses 1.86 millisieverts ( $0.186 \mathrm{rem}$ ) (assuming no hospitalization) as the basis for estimating the collective doses. Implants using iodine-125 are included because doses to exposed individuals approach 1 millisievert $(0.1 \mathrm{rem})$. However, palladium-103 implants are not included because doses to exposed individuals are always less than 1 millisievert (0.1 rem).

In Table 4.9 (Alternative 1), the collective dose per procedure was determined in the following manner. It was assumed that all patients would remain hospitalized until the dose dropped to 1 millisievert $(0.1 \mathrm{rem})$. Thus, the dose to the 
Table 4.9 Estimates of Collective Dose from Therapeutic Radioiodine Procedures for Alternative 1: Annual Limit of 1 millisievert (0.1 rem)

\begin{tabular}{|c|c|c|c|c|c|c|c|}
\hline \multirow{2}{*}{$\begin{array}{c}\begin{array}{c}\text { Therapeutic } \\
\text { Procedure } \\
\text { (radionuclide) }\end{array} \\
\text { Thyroid Ablation }\end{array}$} & \multicolumn{2}{|c|}{$\begin{array}{l}\text { Typical Activity } \\
\text { Administered } \\
(\mathrm{MBq})(\mathrm{mCi})\end{array}$} & \multicolumn{2}{|c|}{\begin{tabular}{l}
\multicolumn{2}{c}{ Collective } \\
Dose/Procedure \\
$(\mathrm{mSv}) \quad$ (rem) \\
\end{tabular}} & \multirow[t]{2}{*}{$\begin{array}{c}\text { Estimated } \\
\text { Procedures } \\
\text { per Year }\end{array}$} & \multicolumn{2}{|c|}{$\begin{array}{c}\text { Total } \\
\text { Collective Dose } \\
\text { (person-Sv (rem)) }\end{array}$} \\
\hline & & & & & & & \\
\hline - iodine- 131 & $\begin{array}{l}1,110 \\
2,220\end{array}$ & $\begin{array}{l}(30) \\
(60)^{*}\end{array}$ & $\begin{array}{l}3.0 \\
3.0\end{array}$ & $\begin{array}{l}(0.3) \\
(0.3)\end{array}$ & $\begin{array}{r}49,000 \\
1,000\end{array}$ & $\begin{array}{r}147 \\
3\end{array}$ & $\begin{array}{r}(14,700) \\
(300)\end{array}$ \\
\hline \multicolumn{8}{|l|}{ Thyroid Cancer } \\
\hline - iodine-131 & 5,550 & (150) & 3.0 & $(0.3)$ & 10,000 & 30 & $(3,000)$ \\
\hline \multicolumn{8}{|c|}{ Permanent Implant } \\
\hline - iodine- 125 & 1,480 & $(40)$ & 2.2 & $(0.22)$ & 2,000 & 4.4 & $(440)$ \\
\hline All Therapeutic $F$ & & & & & 62,000 & 184.4 & $(18,440)$ \\
\hline
\end{tabular}

* Maximum activity administered. This analysis assumes that 98 percent of the patients are typically administered 1,110 millisieverts ( 30 millicuries) and that 2 percent are administered the maximum quantity.

Table 4.10 Estimates of Collective Dose from Therapeutic Radioiodine Procedures for Alternative 2: Limits of 1,110 megabecquerels (30 millicuries) or 0.05 millisievert $(5$ millirems) $/ \mathrm{hr}$

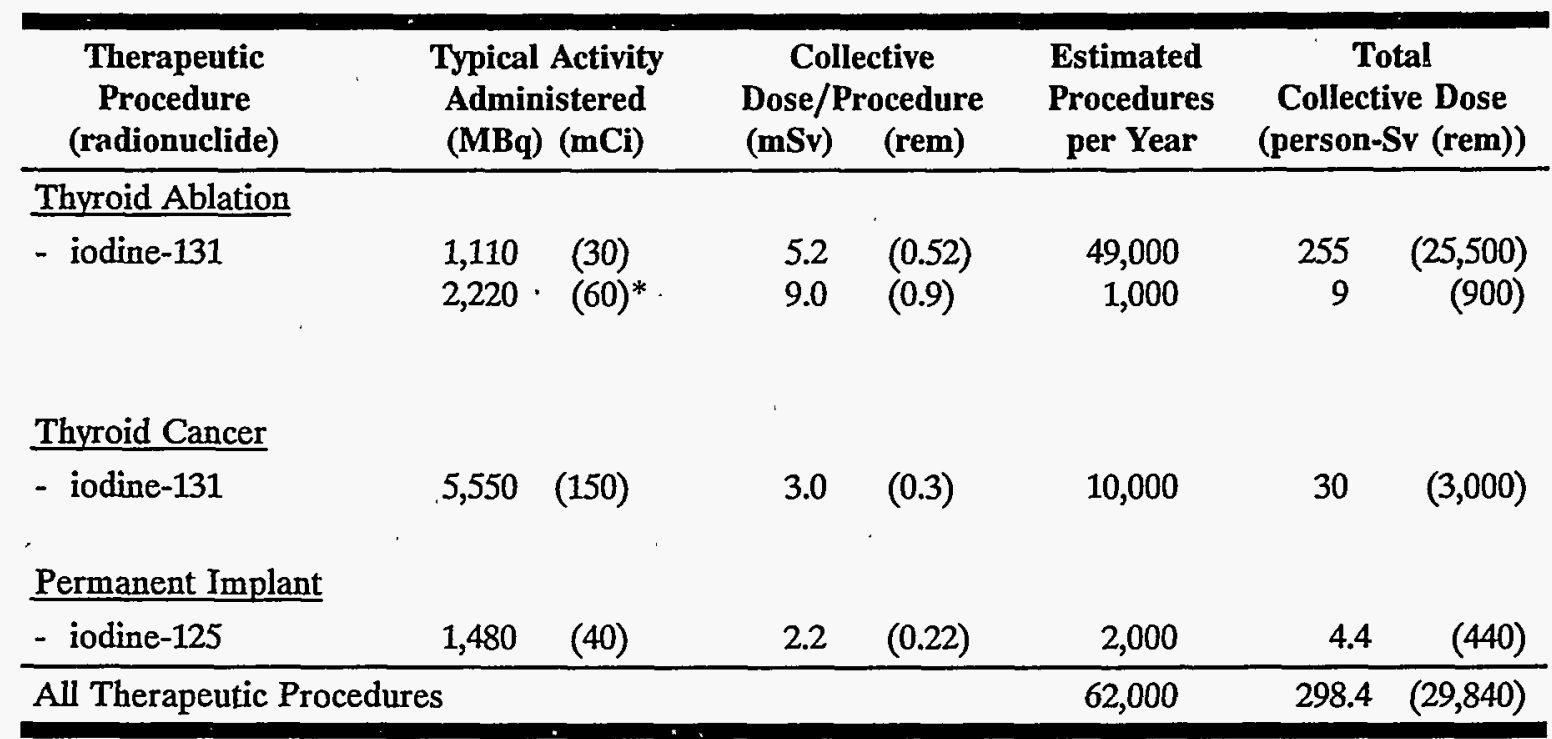

* Maximum activity administered. This analysis assumes that 98 percent of the patients are typically administered 1,110 millisieverts ( 30 millicuries) and that 2 percent are administered the maximum quantity. 
Table 4.11 Estimates of Collective Dose from Therapeutic Radioiodine Procedures for Alternative 3: Annual Limit of 5 millisieverts (0.5 rem)

\begin{tabular}{|c|c|c|c|c|c|c|c|}
\hline $\begin{array}{c}\begin{array}{c}\text { Therapeutic } \\
\text { Procedure } \\
\text { (radionuclide) }\end{array} \\
\text { Thyroid Ablation }\end{array}$ & \multicolumn{2}{|c|}{$\begin{array}{l}\text { Typical Activity } \\
\text { Administered } \\
(\mathbf{M B q})(\mathbf{m C i})\end{array}$} & \multicolumn{2}{|c|}{ 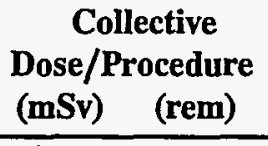 } & $\begin{array}{c}\text { Estimated } \\
\text { Procedures } \\
\text { per Year }\end{array}$ & \multicolumn{2}{|c|}{$\begin{array}{c}\text { Total } \\
\text { Collective Dose } \\
\text { (person-Sv (rem)) }\end{array}$} \\
\hline - iodine-131 & 1,110 & $\begin{array}{l}(30) \\
(6 n) *\end{array}$ & 5.2 & $(0.52)$ & 49,000 & 255 & $(25,500)$ \\
\hline & 2,220 & $(60)^{*}$ & 10.4 & $(1.04)$ & 1,000 & 10.4 & $(1,040)$ \\
\hline \multicolumn{8}{|l|}{ Thyroid Cancer } \\
\hline - iodine-131 & 5,550 & (150) & 5.6 & $(0.56)$ & 10,000 & 56 & $(5,600)$ \\
\hline \multicolumn{8}{|c|}{$\underline{\text { Permanent Implant }}$} \\
\hline - iodine- 125 & 1,480 & (40) & 2.2 & $(0.22)$ & 2,000 & 4.4 & (440) \\
\hline \multicolumn{3}{|c|}{ All Therapeutic Procedures } & & & 62,000 & 325.8 & $(32,580)$ \\
\hline
\end{tabular}

most exposed individual is 1 millisievert (0.1 rem). For iodine- 125 implants, the dose is already less than 1 millisievert ( $0.1 \mathrm{rem})$ so no hospitalization is required. The collective dose per procedure is then assumed to be 3 times the dose to the most exposed individual.

Under Alternative 1, patients administered the typical and maximum quantities of iodine- 131 for thyroid ablation require about 7 and 14 days of hospitalization, respectively, before release can be authorized. Whereas, thyroid cancer patients administered the typical quantity of iodine-131 require about 1.5 days of hospitalization.

In Table 4.10 (Alternative 2), the collective dose per procedure was evaluated in the following manner. For thyroid ablations using the typical activity of iodine-131, no hospitalization is required since the activity is equal to the release limit of 1,110 megabecquerels ( 30 millicuries). The collective dose is 3 times the individual dose (i.e., 1.73 millisieverts $(0.173 \mathrm{rem})$ ) or 5.2 millisieverts $(0.52 \mathrm{rem})$. On the other hand, patients administered the maximum activity require about 1 day of hospitalization before release can be authorized. When released, the maximum dose from these patients will be greater than the dose from a patient administered 1,110 megabecquerels (30 millicuries) due to biological considerations. The estimated dose to the most exposed individual is 3 millisieverts ( $0.3 \mathrm{rem})$. The collective dose is 3 times the individual dose or 9 millisieverts ( $0.9 \mathrm{rem})$. The collective dose per procedure for iodine-125 implants was calculated similar to that for the typical activity administered for thyroid ablation. For thyroid cancer, an administration of 5,500 megabecquerels ( 150 millicuries) requires about 1 day of hospitalization to allow the retained activity to reach the release limit. Upon release, the estimated dose to the maximally exposed individual is 1 millisievert $(0.1 \mathrm{rem})$. Therefore, the collective dose is 3 millisieverts (0.3 rems).

In Table 4.11 (Alternative 3), based on the biological model described by Equation 4, the collective dose per procedure was determined in the following manner. For thyroid ablation, patients administered the typical or maximum activity can be released immediately because the dose from each activity is less than 5 millisieverts $(0.5 \mathrm{rem})$. The individual doses from the typical and maximum activities are 1.73 millisieverts ( $0.173 \mathrm{rem})$ and 3.47 millisieverts (0.347 rem), respectively. Thus, the collective dose is 5.2 millisieverts $(0.52 \mathrm{rem})$ for the typical activity and 10.4 millisieverts $(1.04 \mathrm{rem})$ for the maximum activity. The collective dose per procedure for iodine- 125 implants was calculated in the same manner assuming no hospitalization. For thyroid cancer, administrations of 5,500 megabecquerels 
(150 millicuries) require no hospitalization because the dose to the maximally exposed individual is 1.86 millisieverts $(0.186 \mathrm{rem})$. The collective dose is 5.6 millisieverts $(0.56 \mathrm{rem})$.

\subsubsection{Collective Dose to Breast-Feeding Infants}

The dose to the nursing infant from breastfeeding can be controlled to less than 1 millisievert $(0.1 \mathrm{rem})$ by giving the woman instructions to cease or to interrupt breast-feeding (see Section 4.2.4.4 Summary of Doses to BreastFeeding Infants). The actual doses that would be received by most infants after interruption should be a small fraction of 1 millisievert $(0.1 \mathrm{rem})$ or nothing in the case of cessation. Consequently, there is no reason to calculate the collective dose to nursing infants from breast-feeding since it does not affect the choice of alternative.

\subsection{Value Impact Analysis}

\subsubsection{Estimates of the Potential Costs}

The analysis in Section 4.2 indicates that the 1 millisievert $(0.1 \mathrm{rem})$ per year dose limit imposed by Alternative 1 would result in the smallest collective dose to individuals exposed to released patients. The benefit of smaller doses estimated for Alternative 1 will only be achieved if the patients to whom the radioactive materials have been administered are retained under the control of licensees for longer periods of time. The impact of retaining patients must be assessed in terms of the patient, family, and society as a whole. At a minimum, the economic cost must consider the direct cost of medical resources required to retain the patient in a hospital and the indirect cost resulting from the loss of human resources. Additional consideration should be given to the psychological impact of retention on the affected individual and family members.

Hospitalization will also cause an increase in the dose to the hospital staff and other patients in the hospital. However, the increase in dose to the hospital staff is expected to be low relative to a patient going home earlier because of the precautions taken during hospitalization; e.g., patients are isolated and the hospital staff rarely enters the patient's room.
In the analysis that follows, these costs are calculated assuming that all retained patients will be hospitalized. While retention costs might be less for non-hospital locations, no attempt is made in this analysis to quantify the potential costs.

\subsubsection{Estimates of the Direct Costs of Patient Retention}

\section{Durations of Patient Retention}

Estimates of the periods of hospitalization that patients would need to remain under licensee control for each alternative were discussed in Section 4.2.5.1 Collective Dose to Individuals. Table 4.12 summarizes the duration of retention per therapeutic procedure.

\section{Cost of Patient Retention}

To estimate the annual dollar costs for these periods of retention, one needs only multiply the number of days required for each procedure by the number of procedures per year and the average cost per day of hospitalization. In 1990, the average cost per day in a community hospital was $\$ 687$ (SA92). The per diem cost at the beginning of 1995 is estimated to be $\$ 800$. However, as the current regulations require that patients who are hospitalized due to a therapeutic administration of radiopharmaceuticals be placed in a private room, the $\$ 800$ per day estimate is adjusted to $\$ 1,000$ per day. Using this figure, the potential cost of retaining patients under Alternative 1 is estimated to be $\$ 427$ million. Under Alternative 2, the estimated cost is $\$ 16$ million. And, under Alternative 3, there is no related cost because hospitalization is not required.

\section{Estimates of the Numbers of Breast-Feeding Women Requiring Records and Instructions Under Alternative 3}

The rule associated with Alternative 3 establishes additional requirements for recordkeeping and providing instructions. Before one can determine the costs of these requirements, it is necessary to calculate the number of patient releases involving breast-feeding women that apply to each requirement. 
Table 4.12 Duration of Retention per Therapeutic Procedure

\begin{tabular}{|c|c|c|c|c|c|c|c|}
\hline $\begin{array}{l}\text { Therapeutic } \\
\text { Procedure }\end{array}$ & $\begin{array}{c}\text { Typical } \\
\text { Activity } \\
\text { Administered } \\
(\mathbf{M B q})(\mathbf{m C i})\end{array}$ & $\begin{array}{c}\text { hospital } \\
\text { days per } \\
\text { procedure }\end{array}$ & $\begin{array}{l}\text { total } \\
\text { hospital } \\
\text { days }\end{array}$ & $\begin{array}{l}\text { hospital } \\
\text { days per } \\
\text { procedure }\end{array}$ & $\begin{array}{l}\text { total } \\
\text { hospital } \\
\text { days }\end{array}$ & $\begin{array}{l}\text { days per } \\
\text { procedure }\end{array}$ & $\begin{array}{c}\Sigma \\
\text { procedures } \\
(\mathbf{x} 1000)\end{array}$ \\
\hline \multicolumn{8}{|c|}{$\begin{array}{l}\text { Thyroid Ablation } \\
\text { I- } 131,50,000 \\
\text { procedures/year }\end{array}$} \\
\hline & $\begin{array}{ll}1,110 & (30) \\
2,220 & (60)^{*}\end{array}$ & $\begin{array}{r}7 \\
14\end{array}$ & $\begin{array}{r}343,000 \\
14,000\end{array}$ & $\begin{array}{l}0 \\
1\end{array}$ & $\begin{array}{r}0 \\
1,000\end{array}$ & $\begin{array}{l}0 \\
0\end{array}$ & $\begin{array}{l}0 \\
0\end{array}$ \\
\hline \multicolumn{8}{|c|}{$\begin{array}{l}\text { Thyroid Cancer } \\
\text { I-131, } 10,000 \\
\text { procedures/year }\end{array}$} \\
\hline & $5,550 \quad(150)$ & 1.5 & 70,000 & $1.5^{\dagger}$ & 15,000 & 0 & 0 \\
\hline \multicolumn{8}{|c|}{$\begin{array}{l}\text { Permanent Implant, } \\
\text { I- } 125,2,000 \\
\text { procedures/year }\end{array}$} \\
\hline & $1,480 \quad(40)$ & 0 & 0 & 0 & 0 & 0 & 0 \\
\hline $\begin{array}{l}\text { Total for All } \\
\text { Procedures }\end{array}$ & erapeutic & & 427,000 & & 16,000 & & 0 \\
\hline
\end{tabular}

* Maximum activity administered. This analysis assumes that 98 percent of the patients are typically administered 1,110 millisieverts (30 millicuries) and that 2 percent are administered the maximum activity.

† The analysis under Section 4.2.5.1 Collective Dose to Individuals shows 1 day of hospitalization. However, patients are typically hospitalized for 1 to 2 days. Thus, the actual observed value is shown. 
The number of releases involving breast-feeding women that require instructions under Alternative 3 is calculated in the following manner. First, the total number of administrations potentially requiring instructions for breast-feeding, approximately 4 million, was determined by summing up the number of administrations for all of the radionuclides in Table 4.2 that would require instructions based on Table B.5. For radiopharmaceuticals not identified in Table 4.2 but listed in Table B.5, the number of administrations was assumed to be negligible. Next, from Table 4.3 it was estimated that 13.5 percent of the radiopharmaceuticals are administered to females of childbearing age and that 5 percent of them, based on information in Statistical Abstracts of the United States (SA94), could be breast-feeding (assuming an average breast-feeding period of 1 year). To estimate the number of releases that require instruction, one needs only multiply 4 million by 13.5 percent, and then by 5 percent. Thus, 27,000 reieases of breast-feeding women require instructions.

The number of patient releases involving breastfeeding women that require a record of instructions under Alternative 3 was calculated in the following manner. Using Table B.5, only the radiopharmaceuticals resulting in a dose to the breast-feeding infant exceeding 5 millisieverts $(0.5 \mathrm{rem})$ with no interruption were identified. Of the identified radiopharmaceuticals, only those with a significant number of administrations using the data in Table 4.2 were considered. Based on this analysis, the total number of administrations potentially requiring records for issuance of breast-feeding. instructions was estimated at 1.06 million (i.e., 60,000 iodine-131 administrations for thyroid cancer and ablation plus 1 million technetium-99m pertechnetate administrations). As discussed above, 13.5 percent of the radiopharmaceuticals are administered to females of childbearing age and 5 percent of them could be breast-feeding. To estimate the number of releases that require a record, one needs only multiply 1.06 million by 13.5 percent, and then by 5 percent. Thus, 7,200 releases of breast-feeding women require a record.

\section{Costs of Providing Instructions}

Alternatives 1 and 2 have no requirements for instructions, and therefore, have no related costs. However, the rule associated with Alternative 3 imposes additional costs for providing instructions, including written instructions, on the estimated 1,350 licensees. In the case in which the administered activity could cause a dose from direct radiation exceeding $0.1 \mathrm{rem}$ ( 1 millisievert), instructions would have to be given to 62,000 patients per year at a cost of $\$ 1.4$ million per year. In addition, instructions would have to be given to approximately 27,000 breast-feeding women at a cost of $\$ 0.6$ million per year. In both cases, a cost of $\$ 22$ per patient is estimated. The total estimated cost of instructions is $\$ 2$ million per year.

\section{Costs of Providing Recordkeeping}

Alternatives 1 and 2 have no recordkeeping requirements, and therefore, have no related costs. However, the rule associated with Alternative 3 imposes additional paperwork and recordkeeping requirements on the estimated 1,350 licensees (NRC- and Agreement Statelicensed) that provide diagnostic and therapeutic administrations of radiopharmaceuticals. For therapeutic administrations where releases are not based on the default table of activities and dose rates in Regulatory Guide 8.39, "Release of Patients Administered Radioactive Materials" (NRC97), a record must be maintained for 3 years.

Additionally, if the released patient is a breastfeeding woman and the radiation dose to the nursing infant could result in a total effective dose equivalent exceeding 5 millisievert $(0.5 \mathrm{rem})$ assuming no interruption of breast-feeding, then a record must be maintained, for 3 years, that instructions were provided. In this case, both diagnostic and therapeutic administrations of radiopharmaceuticals could require a record.

It is estimated that approximately 17,200 procedures per year would be subject to these requirements (i.e., (1) 10,000 patients treated with iodine for thyroid cancer and (2) 7,200 administrations to breast-feeding women). A cost of $\$ 17$ per patient is estimated. This results in an annual estimated cost of approximately $\$ 0.3$ million.

\subsubsection{Derivation of Indirect Costs}

\section{Loss of Time}

Indirect costs principally reflect the time and output lost or forfeited by the patient while 
Table 4.13 Annual Attributes of Alternatives 1, 2, and 3

\begin{tabular}{|c|c|c|c|c|c|c|}
\hline \multirow[b]{2}{*}{ Alternative } & \multirow[b]{2}{*}{$\begin{array}{c}\text { Collective Dose } \\
\text { (person-rem) }\end{array}$} & \multirow[b]{2}{*}{$\begin{array}{c}\text { Hospital } \\
\text { Retention } \\
\text { (days) }\end{array}$} & \multicolumn{4}{|c|}{ Cost Estimates } \\
\hline & & & $\begin{array}{c}\text { Hospitalization } \\
\text { cost } \\
\$ \\
\text { (millions) }\end{array}$ & $\begin{array}{c}\text { Value of } \\
\text { lost time } \\
\$ \\
\text { (millions) }\end{array}$ & $\begin{array}{c}\text { Records \& } \\
\text { Instructions } \\
\$ \\
\text { (millions) }\end{array}$ & $\begin{array}{c}\text { Psychological } \\
\text { cost } \\
\text { (relative) }\end{array}$ \\
\hline 1 & 18,400 & 427,000 & 427 & 25.62 & 0 & High \\
\hline 2 & 29,840 & 16,000 & 16 & 0.96 & 0 & Moderate \\
\hline 3 & 32,580 & 0 & 0 & 0 & 2.3 & Low \\
\hline
\end{tabular}

retained in a controlled environment. Indirect costs may also be incurred by individuals other than the patient who may forgo economic activities to accommodate a family member's hospital retention. Economic activities include occupational work that is lost to either the patient or his or her employer as well as non-occupational (e.g., domestic) work which must be performed by someone else at the expense of the patient.

The conversion of time lost from economic activities to equivalent dollars is most fairly achieved by means of the gross national product (GNP). The GNP is considered the most comprehensive measure of the country's economic activity and includes the market value of all goods and services that have been bought for final use during a year. From the GNP of about $\$ 5,600$ billion in 1991 , the gross average annual per capita income of about $\$ 22,000$ is derived. The value of $\$ 22,000$ per year corresponds to $\$ 60$ per day. To estimate the equivalent dollar value for the number of days lost due to retention of an individual for a therapeutic procedure, one need only multiply $\$ 60$ by the days of retention for the procedure presented in Table 4.12. The value of the days lost for each alternative is shown in Table 4.13.

\subsubsection{Evaluation of Psychological Costs}

Retention of patients in a hospital by design necessitates that the patient be "isolated" and that human contact, inclusive of family members, is either avoided or minimized. Such isolation may bring about numerous changes and impositions in the lives of the patient and family members that may in part be linked to, but are not reflected in, the direct and indirect economic costs identified above. The wide variety of deterioration in the quality of life brought on by illness is frequently referred to as psychological costs. For thyroid cancer or dysfunction requiring therapeutic doses of iodine-131 for example, a deterioration in the quality of life may be precipitated by the loss of bodily function, a lifetime dependence on medication, hormonal instability, uncertainty of normal life-expectancy, disruption of normal daily routines, and reduced financial security related to employment, lost earnings, and medical expenses.

While some of these elements of psychological costs are the result of the disease itself, others such as disruption of normal routines, social isolation, and enhanced financial strain are clearly elements of psychological costs that are directly related to patient retention. The conversion of psychological cost from patient retention to equivalent dollars is complex such that an evaluation is highly subjective and dependent upon the individual situation. Instead, this analysis uses a qualitative and reasonable approach to scope the range of possible responses. As shown in Table 4.13, comparison is provided on a relative scale.

\subsubsection{Costs and Benefits of Alternatives}

Table 4.13 summarizes the data pertaining to the annual attributes for each of the three alternatives under consideration. To determine the preferred alternative, the costs and benefits that result when Alternatives 1 and 3 are each compared with Alternative 2 (the status quo) were analyzed. The results are shown in Table 4.14. A value of $\$ 2,000$ 
Table 4.14 Annual Costs and Benefits of Alternatives 1 and 3 Compared to Alternative 2 (The Status Quo)

\begin{tabular}{|c|c|c|c|c|}
\hline \multirow[b]{2}{*}{ Alternative } & \multicolumn{2}{|c|}{ Collective-Dose* } & \multicolumn{2}{|l|}{ Costs } \\
\hline & $\begin{array}{l}\text { Dose Averted } \\
\text { (person-rem) }\end{array}$ & $\begin{array}{c}\text { Associated } \\
\text { Value } \\
\$ \\
\text { (millions) }\end{array}$ & $\begin{array}{c}\text { Hospitalization, Lost Time, } \\
\text { Records and Instructions } \\
\$ \\
\text { (millions) }\end{array}$ & $\begin{array}{c}\text { Net Benefit } \\
\$ \\
\text { (millions) }\end{array}$ \\
\hline 1 & 11,440 (savings) & 23 (savings) & 435 (cost) & $-412($ net cost) \\
\hline 2 & 0 & 0 & 0 & 0 \\
\hline 3 & $-2,740$ (cost) & $-5(\cos t)$ & -14 (savings) & 9 (net savings) \\
\hline
\end{tabular}

* A value of $\$ 2,000$ per person-rem was used as the conversion factor for dose averted.

per person-rem was used as the conversion factor for dose averted (NRC95).

Because the benefits and costs for all alternatives occur in the same year, and remain the same each year for the therapeutic procedures discussed, a discounted flow of the benefits and costs of this rulemaking is not required.

\subsection{Evaluation of the Alternatives With Respect to Accepted Radiation Protection Principles}

Selection of the 5-millisieverts ( 0.5 -rem) total effective dose equivalent per year criterion is consistent with: the Commission's provision in 10 CFR 20.1301(c) for authorizing a licensee to operate up to this limit; the recommendations of the International Commission on Radiological Protection (ICRP) in ICRP Publication 60, "1990 Recommendations of the International Commission on Radiological Protection"; and the recommendations of the NCRP in NCRP Report No. 116, "Limitation of Exposure to Ionizing Radiation." Each of these provide a basis for allowing individuals to receive annual doses up to 5 millisieverts $(0.5 \mathrm{rem})$ under certain circumstances. Both ICRP and NCRP recommend that an individual be allowed to receive a dose up to 5 millisieverts $(0.5 \mathrm{rem})$ in a given year in temporary situations where exposure

\section{DECISION RATIONALE}

to radiation is not expected to result in doses above 1 millisievert $(0.1 \mathrm{rem})$ for long periods of time. The recommendations of the ICRP and NCRP are based on their finding that annual doses in excess of 1 millisievert $(0.1 \mathrm{rem})$ to a small group of people, provided that they do not occur often to the same group, need not be regarded as especially hazardous. Although the risk is potentially greater under Alternative 3 , it is still within the range of acceptable risk for radiation exposure accepted by the NRC (as implemented under the revised 10 CFR Part 20).

1. All of the alternatives are acceptable according to generally accepted radiation protection principles, such as those expressed by NRC, NCRP, and ICRP (see Section 4.4 Evaluation of the Alternatives With Respect to Accepted Radiation Protection Principles).

2. Alternative 1 is considerably more expensive to the public compared to Alternative 2 (the status quo) or Alternative 3. Even neglecting the psychological costs, which have not been expressed in dollar terms, the additional cost of Alternative 1 relative to Alternative 2 is about $\$ 412,000,000$ per year, mostly due to increased national health care costs. In view of this, Alternative 1 may be dismissed. 
3. Alternative 3 relative to Alternative 2 has a net value of about $\$ 9,000,000$ per year, mostly due to lower health care costs. Also, Alternative 3 has psychological benefits to patients and their families. Thus, Alternative 3 is cost effective in comparison with Alternative 2.

4. Basing the patient release criteria in 10 CFR 35.75 on the dose to individuals exposed to a patient provides a consistent, scientific basis for such decisions that treats all radionuclides on a risk-equivalent basis. The dose delivered by an initial activity of 1,110 megabecquerels ( 30 millicuries) or a dose rate at 1 meter of 0.05 millisievert (5 millirems) per hour varies greatly from one radionuclide to another. Thus, while the values in the current 10 CFR 35.75 may be appropriate for iodine-131, they are too high for some other radionuclides and too low for others.

5. A dose-based rule no longer restricts patient release to a specific activity, and therefore would permit the release of patients with activities that are greater than currently allowed. This is especially true when casespecific factors are evaluated to more accurately assess the dose to other individuals. For the case of thyroid cancer, in those occasional cases where multiple administrations in a year of 1,110 megabecquerels (30 millicuries) or less of iodine-131 are now administered to a patient, it may be possible to give all of the activity in a single administration. This would reduce the potential for repeated exposures to hospital staff and to those providing care to the released patient. Additionally, this would provide physicians with the flexibility to not have to fractionate doses to avoid hospitalization to meet the current requirements, which may lead to a more effective treatment.

6. Shorter hospital stays provide emotional benefits to patients and their families. Allowing earlier reunion of families can improve the patient's state of mind, which in itself may improve the outcome of the treatment and lead to the delivery of more effective health care.

\section{IMPLEMENTATION}

No impediments to implementation of the recommended alternative have been identified. The staff has prepared a regulatory guide (NRC97) for licensees which provides, in part, simple methods to evaluate the dose to the individual member of the public likely to receive the highest dose from the released patient. This will enable licensees to determine when a patient may be released from their control. 


\section{REFERENCES}

ACR82 American College of Radiology, "Manpower III: A Report of the ACR Committee on Manpower," Chicago, IL.

ACR75 American College of Radiology, "Survey on Regionalization in Nuclear Medicine," Washington, DC.

ACS93 American Cancer Society, "Cancer Facts \& Figures - 1992," Atlanta, GA.

AG92 Agbi, C.B., M. Bernstein, N. Laperriere, P. Leung, M. Lumley, 1992, "Patterns of Recurrence of Malignant Astrocytoma following Stereotactic Interstitial

Brachytherapy with Iodine-125 Implants," Int. J. Radiat. Oncol. Biol. Phys. 23(2):321.

BL88 Blake, G.M., M.A. Zivanovic, R.M. Blaquiere, D.R. Fine, A.J. McEwan, D.M. Ackery, 1988, "Strontium-89

Therapy: Measurement of Absorbed Dose to Skeletal Metastases,"

J. Nucl. Med. 29:549.

BL87 Blake, G.M., M.A. Zivanovic, A.J. McEwan, B.R. Condon, D.M. Ackery, 1987, "Strontium-89 Therapy: Strontium Kinetics and Dosimetry in Two Patients Treated for Metastasizing Osteosarcoma," Br. J. Radiol. 60:253.

BL71 Blum, M., R. Chandra, C.H. Marshall, 1971, "Environmental Contamination with 131-iodine Related to the Treatment of Hyperthyroidism and Carcinoma of the Thyroid Gland," IEEE Trans. Nucl. Sci., Ns-18(1):57.

BU71 Buchan R.C.T. and J.M. Brindle, 1971, "Radioiodine Therapy to Outpatients - The Radiation Hazard," Br. J. Radiol. 44:973.
BU70

CA88

CA87

$\mathrm{CH} 80$

CL89

CO87

DE86

N.F, W.U. Shipley, M.P. O'Leary, P.J. Biggs, G.R. Prout, Jr., 1986, "Preoperative Irradiation Lymphadenectomy and I-125 Implantation for Patient with Localized Carcinoma of the Prostate," Int. J. Radiat. Oncol. Biol. Phys. 12:1779 
DG79

DeGroot, L.J., 1979, "The Thyroid,"

In: Textbook of Medicine, P.B.

Beeson, W. McDermott, J.B.

Wyngaarden, Eds., W.B. Saunders

Company, Philadelphia, PA.

EH87

Ehrhardt, G.J. and D.E. Day, 1987,

"Therapeutic Use of Y-90

Microspheres," Nucl. Med. Biol.

14:233.

FDA85 Food and Drug Administration, "Radiation Experience Data (RED), 1980, Survey of U.S. Hospitals," Department of Health, Education and Welfare, Publication FDA 86-8253.

FI89 Finkler, N.J., A.I. Kassis, M.G. Muto, K. Weadock, S.S. Tumeh, V.R. Zurawski, Jr., R.C. Knapp, 1989, "Intraperitoneal

Radioiodinated OC 125 in Patients with Advanced Ovarian Cancer: Phase I Study," J. Nucl. Med. 30:904.

FL92 Fleischman, E.H., A.R. Kágan, O.E. Streeter, J. Tyrell, M. Wollin, C.A. Leagre, J.C. Harvey, 1992, "Iodine-125 Interstitial Brachytherapy in the Treatment of Carcinoma of the Lung," J. Surg. Oncol. 49(1):25.

FR88 Fritjofsson, A., D.J. Cederlund, B.J. Norlen, H. Wicklund, 1988, "Combined Therapy with Interstitial Gold Implantation and External Irradiation in the Management of Prostate Cancer," Scand. J. Urol. Nephrol. Suppl. 110:117.

FU91 Fuks, A., S.A. Lerbel, K.E. Wallner, C.B. Begg, W.R. Fair, L.L.

Anderson, 1991, "The Effect of Local Control on Metastatic Carcinoma of the Prostate: Long Term Results in Patients Treated with I-125," Int. J. Radiat. Oncol. Biol. Phys. 21:537.

HA74 Harbert, J.C. and S. N. Wells, 1974, "Radiation Exposure to the Family of Radioactive Patients," J. Nucl. Med. 15(10):887.
Herba, M.J., F.F. Illescas, M.P. Thirlwell, G.J. Boos, L. Rosenthall, M. Atri, P.M. Bret, 1988, "Hepatic Malignancies: Improved Treatment with Intraarterial Y-90," Radiology 169:311.

HE82

Herr, H., 1982, "Pelvic

Lymphadenectomy and Iodine- 125

Implantation in Genitourinary

Tumors," In: Fundamental

Principles and Surgical Techniques,

D.E. Johnson, M.A. Boileau, Eds., Duluth, MN, Grune and Stratton, 63.

ICRP89 International Commission on Radiological Protection, 1989, "Agedependent Doses to Members of the Public from Intake of Radionuclides: Part 1," ICRP Publication No. 56, Pergamon Press, Oxford, UK.

ICRP87 International Commission on Radiological Protection, 1987, "Radiation Dose to Patients from Radiopharmaceuticals," ICRP Publication No. 53, Pergamon Press, Oxford, UK.

ICRP78 International Commission on Radiological Protection, 1978, "Limits for Intakes of Radionuclides by Workers," ICRP Publication No. 30, Part 1, Pergamon Press, Oxford, UK.

JA81 Jackson, G.L. and N. M. Blosser, 1981, "Intracavitary Chromic Phosphate (P-32) Colloidal Suspension Therapy," Cancer 48:25986.

JA78 Jacobson, A.P., P.A. Plato, D. Toeroek, 1978, "Contamination of the Home Environment by Patients Treated with Iodine-131," Am. J. Public Health 68(3):225.

JO83 Johnson, J.L. and D.L. Abernathy, 1983, "Diagnostic Imaging Procedure Volume in the U.S.," Radiology 146:851. 
JOH83

Johns, H.E. and J.R. Cunningham, 1983, "The Physics of Radiology," Fourth Edition, Charles C. Thomas Publisher, Springfield, IL.

KA81 Kaplan, W.D., R.E. Zimmerman, W.D. Bloomer, R.C. Knapp, S.J. Adelstein, 1981, "Therapeutic Intraperitoneal P-32: A Clinical Assessment of the Dynamics of Distribution," Radiology 138:683.

KE87 Ketring, A.R., 1987, ${ }^{1153}$ Sm-EDTMP and ${ }^{186} \mathrm{Re}-\mathrm{HEDP}$ as Bone

Therapeutic Radiopharmaceuticals," Nucl. Med. Biol. 14:223.

KL87 Kloiber, R., C.P. Molnar, M. Barnes, 1987, "Sr-89 Therapy for Metastatic

Bone Disease: Scintigraphic and Radiographic Follow Up," Radiology 163:719.

KO75 Kohler, G. and C. Milstein, 1975, "Continuous Cultures of Fused Cells Secreting Antibody of Predefined Specificity," Nature 256:495.

LA90 Lattimer, J.C., L.A. Corwin, J. Stapleton, W.A. Volkert, G.J. Ehrhardt, A.R. Ketring, S.K. Anderson, J. Simon, W.F. Goeckeler, 1990, "Clinical and Clinicopathologic Response of Anine Bone Tumor Patients to Treatment with Samarium-153-EDTMP," J. Nucl. Med. 31:1316.

LE85 Lenhard, R.E., S.E. Order, J.J. Spunberg, S.O. Asbell, S.S. Leibel, 1985, "Isotopic Immunoglobulin: A New Systemic Therapy for Advanced Hodgkin's Disease," J. Clin. Oncol. 3:1296.

MA88 Maxon, H.R., E.A. Deutsch, S.R. Thomas, K. Libson, S.J. Lukes, C.C. Williams, S. Ali, 1988, "Re-186(Sn) HEDP for Treatment of Multiple Metastatic Foci in Bone: Human Distribution and Dosimetric Studies," Radiology 166:501.
MA78 Martini, N., A.H. Freiman, R.C. Watson, B.S. Hilaris, 1978, "Intrapericardial Instillation of Radioactive Chromic Phosphate in Malignant Pericardial Effusion," AJR 128:639.

MA73 Marshall C.H., R. Chandra, M. Blum, 1973, "Contamination of Air and Surroundings by Patients Treated with Large Quantities of Iodine-131 for Thyroid Carcinoma," CONF-730907 Part II, W.S. Snyder, Ed., 1169.

ME90 Meigooni, A.S., S. Sabnis, R. Nath, 1990, "Dosimetry of Palladium-103 Brachytherapy Sources for Permanent Implants," Endocurietherapy Hyperthermia Oncology 6:107.

ME86 Mettler, F.A. Jr., J.H. Christie, A.G. Williams, R.D. Moseley, C.A. Kelsey, 1986, "Population Characteristics and Absorbed Dose to the Population from Nuclear Medicine: United States - 1982," Health Physics 50(5):619.

ME85 Mettler, F.A. Jr., A.G. Williams, J.H. Christie, R.D. Moseley, C.A. Kelsey, 1985, "Trends and Utilization of Nuclear Medicine in the United States: 1972-1982," J. Nucl. Med 26:201.

MO92 Mohiuddin, M., F. Rosato, D. Barbot, A. Schuricht, W. Biermann, R. Cantor, 1992, "Long-term Results of Combined Modality Treatment with I-125 Implantation for Carcinoma of the Pancreas," Int. J. Radiat. Oncol. Biol. Phys. 23(2):305.

MO88 Morton, J.D. and R.E. Peschel, 1988, "Iodine-125 Implants versus External Beam Therapy for StageA2, B and C Prostate Cancer," Int. J. Radiat. Oncol. Biol. Phys. 14:1153.

NCRP70 National Council on Radiation Protection and Measurements, 1970 "Precautions in the Management of Patients who have Received Therapeutic Amounts of Radionuclides," NCRP Report No. 37, Washington, DC. 
N180 Nishizawa, K, K. Ohara, M. Ohshima, H. Maekoshi, T. Orito, T. Watanabe, 1980, "Monitoring of Iodine Excretions and Used Materials of Patients Treated with I-131," Health Physics 38(4):467.

NRC97 U.S. Nuclear Regulatory Commission, Regulatory Guide 8.39, "Release of Patients Administered Radioactive Materials," Washington, DC, 1997.

NRC95 U.S. Nuclear Regulatory Commission, November 1995, NUREG/BR-0058, Revision 2, "Regulatory Analysis of the U.S. Nuclear Regulatory Commission," Final Report, Washington, DC.

PE86

PE42

PO93

OR85 Order, S.E., G.B. Stillwagon, J.L. Klein, P.K. Leichner, S.S. Siegelman, E.K. Fischman, D.S. Ettinger, T. Haulk, K. Kopher, K. Finney, M. Surdyke, S. Sels, S. Leibel, 1985, "Iodine-131 Antiferritine, A New Treatment Modality in Hepatoma: A Radiation Therapy Oncology Group Study," J. Clin. Oncol. 3:1573.

OS92 Ostertag, C.B. and F.W. Kreth, 1992, "Iodine-125 Interstitial Irradiation for Cerebral Gliomas," Acta Neurochi (Austria) 119(1-4):53, Freiburg University, Federal Republic of Germany.

PA87 Park, C.H., J.H. Suh, H.S. Yoo, J.T. Lee, D.I. Kim, B.S. Kim, 1987, "Treatment of Hepatocellular Carcinoma (HCC) with Radiolabeled Lipiodol: A Preliminary Report," Nucl. Med. Commun. 8:1075.

RI90 Riva, P., S. Lazzari, M. Agostini, G. Sarti, G. Moscatelli, G. Franceschi, A. Spinelli, G. Vecchietti, R. Tassini, D. Tirindelli, 1990, "Intracavitary Radioimmunotherapy Trails in Systemic Gastrointestinal and Ovarian Carcinomas: Pharmacokinetic, Biologic and Dosimetric Problems," In: Schmidt HAE, Chambron J., Eds., Nuclear Medicine Quantitative Analysis in Imaging and Function. Schattauer, Stuttgart, 586. 
RO87

Robinson, R.G., J.A. Spicer, D.F. Preston, A.V. Wegst, N.L. Martin, 1987, "Treatment of Metastatic Bone Pain with Strontium-89," Nucl. Med. Biol. 14:219.

RO77 Roberts, D.J., 1977, "32P-sodium Phosphate Treatment of Metastatic Malignant Disease," Clin. Nucl. Med. 2:64.

ROE90 Roesler, H., J. Triller, L. Geiger, H.U. Baer, H.F. Beer, L. Blumgart, 1990, Superselective 90Y-resin Embolization Therapy of Solid Tumors," Eur. J. Nucl. Med. 16:439.

RU92 Rustig, S.N., S.S. Hahn, 1992, "Advantages of using High Activity I-125 Seeds in Temporary Interstitial Breast Implants," Med. Dosim. 17(4):217.

SA94 U.S. Bureau of the Census, Statistical Abstract of the United States: 1994 (114th edition.)

Washington, DC.

SC92 Scharfen, C.O., P.K. Sneed, W.M. Wara, D.A. Larson, T.L. Phillips, M.D. Prados, K.A. Weaver, M. Malec, P. Acord, K.R. Lamborn, 1992, "High Activity Iodine-125 Interstitial Implant for Gliomas," Int. J. Radiat. Oncol. Biol. Phys. 24(4):583.

SC90 Schroder, L.E., H.R. Maxon, 1990, "Re-186-HEDP Palliation of Painful Skeletal Metastases," presented at the European Association of Nuclear Medicine Congress, Amsterdam.
Silberstein, E.B., C. Williams, 1985, "Strontium-89 Therapy for the Pain of Osseous Metastases," J. Nucl. Med. 26:345.

ST88

TU89

WH88 Yang, S.C. Walker, E.A. Cozzi, J.E. Niederhuber, J.W. Gyves, W.D. Ensminger, M.C. Tuscan, 1984, "Hepatic Arterial Perfusion Scintigraplyy with Tc-99m MAA," Radiology 152:167. 


\section{APPENDIX A}

\section{PARAMETERS AND CALCULATIONS FOR DETERMINING RELEASE QUANTITIES AND DOSE RATES FOR RADIONUCLIDES USED IN MEDICINE}

Table A.1 Half-Lives and Exposure Rate Constants of Radionuclides Used in Medicine*

\begin{tabular}{|c|c|c|c|c|c|}
\hline Radionuclide & $\begin{array}{c}\text { Half-Life } \\
\text { (days) }\end{array}$ & $\begin{array}{c}\text { Exposure } \\
\text { Rate Constant } \\
(\mathrm{R} / \mathrm{mCi}-\mathbf{h} \text { at } 1 \mathrm{~cm})\end{array}$ & Radionuclide & $\begin{array}{c}\text { Half-Life } \\
\text { (days) }\end{array}$ & $\begin{array}{c}\text { Exposure } \\
\text { Rate Constant } \\
(\mathbf{R} / \mathbf{m C i}-\mathbf{h} \text { at } 1 \mathrm{~cm})\end{array}$ \\
\hline $\mathrm{Ag}-111$ & 7.45 & 0.15 & Pd-103 implant & 16.96 & $1.48^{* *}$ \\
\hline Au-198 & 2.696 & 2.3 & Re-186 & 3.777 & 0.2 \\
\hline $\mathrm{Cr}-51$ & 27.704 & 0.16 & Re-188 & 0.708 & 0.26 \\
\hline $\mathrm{Cu}-64$ & 0.529 & 1.2 & Sc-47 & 3.351 & 0.56 \\
\hline $\mathrm{Cu}-67$ & 2.578 & 0.58 & Se-75 & 119.8 & 2.6 \\
\hline Ga-67 & 3.261 & 0.753 & Sm-153 & 1.946 & 0.425 \\
\hline I-123 & 0.55 & 1.61 & Sn-117m & 13.61 & 1.48 \\
\hline $\mathrm{I}-125$ & 60.14 & 1.42 & Sr-89 & 50.5 & $\mathrm{NA}^{+}$ \\
\hline I-125 implant & 60.14 & $1.11^{\ddagger}$ & Tc-99m & 0.251 & 0.756 \\
\hline I-131 & 8.04 & 2.2 & Tl-201 & 3.044 & 0.447 \\
\hline In-111 & 2.83 & 3.21 & $Y-90$ & 2.67 & $\mathrm{NA}^{+}$ \\
\hline Ir-192 implant & 74.02 & $4.59^{\ddagger}$ & Yb-169 & 32.01 & 1.83 \\
\hline P-32 & 14.29 & $\mathrm{NA}^{+}$ & & & \\
\hline
\end{tabular}

* References for half-lives and exposure rate constants are shown in Table A-2.

** A. Meigooni, S. Sabnis, and R. Nath, "Dosimetry of Palladium-103 Brachytherapy Sources for Permanent Implants," Endocurietherapy Hyperthermia Oncology, Volume 6, April 1990. The exposure rate constant given is an "apparent" value (i.e., with respect to an apparent source activity) and takes into account the attenuation of gamma rays within the implant capsule itself.

\# R. Nath, A.S. Meigooni, and J.A. Meli, "Dosimetry on Transverse Axes of ${ }^{125}$ I and ${ }^{192}$ Ir Interstitial Brachytherapy Sources," Medical Physics, Volume 17, Number 6, November/December 1990. The exposure rate constant given is a measured value averaged for several source models and takes into account the attenuation of gamma rays within the implant capsule itself.

$\dagger$ Not applicable (NA) because the release activity is not based on beta emissions.

NOTE: Although non-byproduct materials are not regulated by the NRC, information on non-byproduct material is included in this regulatory analysis for the convenience of the license. 
Table A.2 Exposure Rate Constants, Release Activities, and Release Dose Rates ${ }^{\dagger}$.

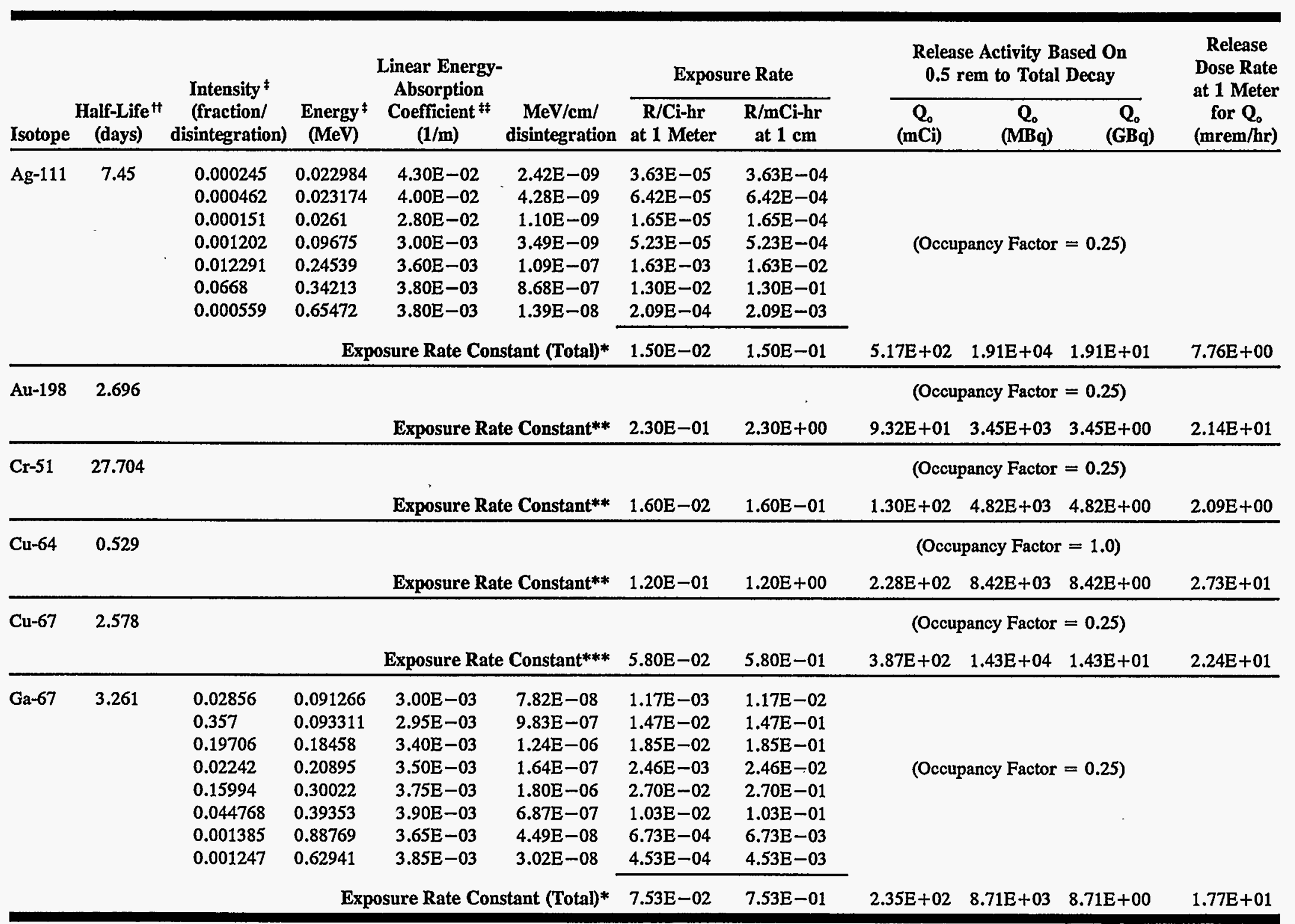


Table A.2 Exposure Rate Constants, Release Activities, and Release Dose Rates (Continued) ${ }^{\dagger}$

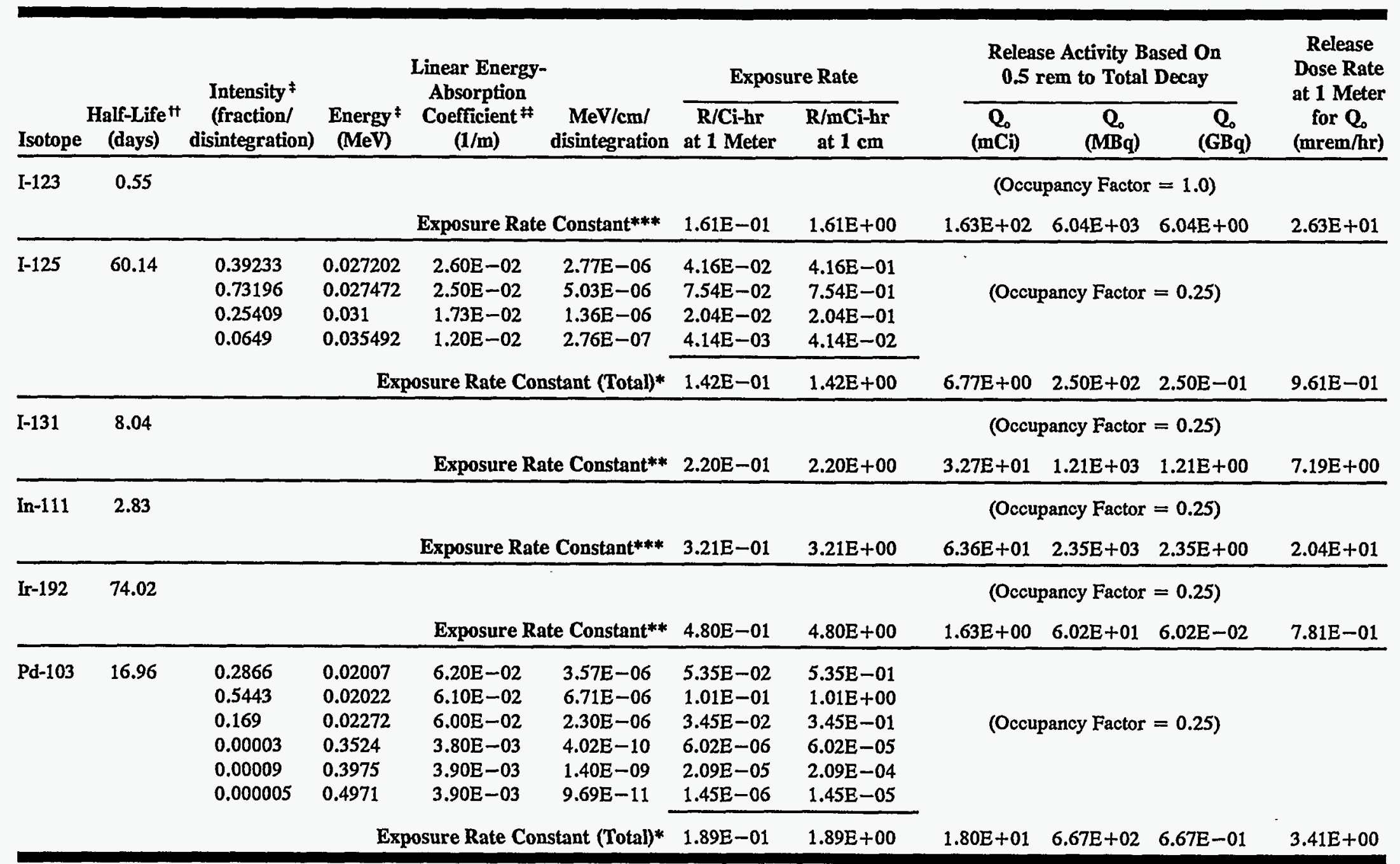


Table A.2 Exposure Rate Constants, Release Activities, and Release Dose Rates (Continued) ${ }^{\dagger}$

\begin{tabular}{|c|c|c|c|c|c|c|c|c|c|c|c|}
\hline \multirow[b]{2}{*}{ Isotope } & \multirow[b]{2}{*}{$\begin{array}{l}\text { Half-Life }^{t t} \\
\text { (days) }^{\text {(day }}\end{array}$} & \multirow{2}{*}{$\begin{array}{c}\text { Intensity }{ }^{\ddagger} \\
\text { (fraction/ } \\
\text { disintegration) }\end{array}$} & \multirow[b]{2}{*}{$\begin{array}{c}\text { Energy }{ }^{\ddagger} \\
(\mathrm{MeV})\end{array}$} & \multirow{2}{*}{$\begin{array}{l}\text { Linear Energy- } \\
\text { Absorption } \\
\text { Coefficient }{ }^{\ddagger \ddagger} \\
(\mathbf{1} / \mathrm{m})\end{array}$} & \multirow[b]{2}{*}{$\begin{array}{c}\mathrm{MeV} / \mathrm{cm} / \\
\text { disintegration }\end{array}$} & \multicolumn{2}{|c|}{ Exposure Rate } & \multicolumn{3}{|c|}{$\begin{array}{l}\text { Release Activity Based On } \\
0.5 \text { rem to Total Decay }\end{array}$} & \multirow{2}{*}{$\begin{array}{c}\text { Release } \\
\text { Dose Rate } \\
\text { at } 1 \text { Meter } \\
\text { for } Q_{\circ} \\
(\mathrm{mrem} / \mathrm{hr})\end{array}$} \\
\hline & & & & & & $\begin{array}{l}\mathrm{R} / \mathrm{Ci}-\mathrm{hr} \\
\text { at } 1 \text { Meter }\end{array}$ & $\begin{array}{l}\mathrm{R} / \mathrm{mCi}-\mathrm{hr} \\
\text { at } 1 \mathrm{~cm}\end{array}$ & $\begin{array}{c}\mathrm{Q}_{0} \\
(\mathrm{mCi})\end{array}$ & $\begin{array}{c}\mathrm{Q}_{\mathrm{o}} \\
(\mathrm{MBq})\end{array}$ & $\begin{array}{c}\mathbf{Q}_{0} \\
(\mathrm{GBq})\end{array}$ & \\
\hline \multirow[t]{2}{*}{$\operatorname{Re}-186$} & 3.777 & & & & & & & \multicolumn{3}{|c|}{ (Occupancy Factor $=0.25$ ) } & \\
\hline & & & & \multicolumn{2}{|c|}{ Exposure Rate Constant*** } & $2.00 \mathrm{E}-02$ & $2.00 \mathrm{E}-0.1$ & $7.65 \mathrm{E}+02$ & $2.83 E+04$ & $2.83 E+01$ & $1.53 \mathrm{E}+01$ \\
\hline \multirow[t]{2}{*}{$\operatorname{Re}-188$} & 0.708 & & & & & & & \multicolumn{3}{|c|}{ (Occupancy Factor $=1.0)$} & \\
\hline & & & & \multicolumn{2}{|c|}{ Exposure Rate Constant*** } & $2.60 \mathrm{E}-02$ & $2.60 \mathrm{E}-01$ & $7.85 \mathrm{E}+02$ & $2.91 \mathrm{E}+04$ & $2.91 \mathrm{E}+01$ & $2.04 \mathrm{E}+01$ \\
\hline \multirow[t]{2}{*}{ Sc-47 } & 3.351 & & & & & & & (Occup & ancy Factor & $=0.25)$ & \\
\hline & & & & \multicolumn{2}{|c|}{ Exposure Rate Constant** } & $5.60 \mathrm{E}-02$ & $5.60 \mathrm{E}-01$ & $3.08 \mathrm{E}+02$ & $1: 14 \mathrm{E}+04$ & $1.14 \mathrm{E}+01$ & $1.72 \mathrm{E}+01$ \\
\hline \multirow[t]{2}{*}{ Se-75 } & 119.8 & & & & & & & (Occup & ancy Factor & $=0.25)$ & \\
\hline & & & & \multicolumn{2}{|c|}{ Exposure Rate Constant** } & $2.00 \mathrm{E}-01$ & $2.00 \mathrm{E}+00$ & $2.41 E+00$ & $8.92 \mathrm{E}+01$ & $8.92 \mathrm{E}-02$ & $4.82 \mathrm{E}-01$ \\
\hline \multirow[t]{11}{*}{$\mathrm{Sm}-153$} & 1.946 & 0.17263 & 0.040902 & $7.70 \mathrm{E}-03$ & $5.44 \mathrm{E}-07$ & $8.15 E-03$ & $8.15 \mathrm{E}-02$ & & & & \\
\hline & & 0.31218 & 0.041542 & $7.30 \mathrm{E}-03$ & $9.47 \mathrm{E}-07$ & $1.42 \mathrm{E}-02$ & $.1 .42 \mathrm{E}-01$ & & & & \\
\hline & & 0.12217 & 0.047 & $4.60 \mathrm{E}-03$ & $2.64 \mathrm{E}-07$ & $3.96 \mathrm{E} \div 03$ & $3.96 \mathrm{E}-02$ & & & & - \\
\hline & & 0.0517 & 0.069672 & $3.45 \mathrm{E}-03$ & $1.24 \mathrm{E}-07$ & $1.86 \mathrm{E}-03$ & $1.86 \mathrm{E}-02$ & & & & \\
\hline & & 0.00194 & 0.075422 & $3.35 \mathrm{E}-03$ & $4.90 \mathrm{E}-09$ & $7.35 \mathrm{E}-05$ & $.7 .35 E-04$ & (Occup & ancy Factor & $=0.25)$ & \\
\hline & & 0.002 & 0.083366 & $3.20 \mathrm{E}-03$ & $5.34 \mathrm{E}-09$ & $8.00 \mathrm{E}-05$ & $8.00 \mathrm{E}-04$ & & & & \\
\hline & & 0.00158 & 0.089484 & $3.00 \mathrm{E}-03$ & $4.24 \mathrm{E}-09$ & $6.36 \mathrm{E}-05$ & $6.36 \mathrm{E}-04$ & & & & \\
\hline & & 0.00718 & 0.09743 & $3.00 \mathrm{E}-03$ & $2.10 \mathrm{E}-08$ & $3.15 \mathrm{E}-04$ & $3.15 \mathrm{E}-03$ & & & & \\
\hline & & 0.283 & 0.10318 & $3.00 \mathrm{E}-03$ & $8.76 \mathrm{E}-07$ & $1.31 \mathrm{E}-02$ & $1.31 \mathrm{E}-01$ & & & & \\
\hline & & 0.002775 & 0.42266 & $3.85 \mathrm{E}-03$ & $4.52 \mathrm{E}-08$ & $6.77 \mathrm{E}-04$ & $6.77 \mathrm{E}-03$ & & & & \\
\hline & & & \multicolumn{3}{|c|}{ Exposure Rate Constant (Total)* } & $4.23 E-02$ & $4.25 \mathrm{E}-01$ & $6.99 \mathrm{E}+02$ & $2.59 \mathrm{E}+04$ & $2.59 \mathrm{E}+01$ & $2.97 \mathrm{E}+01$ \\
\hline
\end{tabular}


Table A.2 Exposure Rate Constants, Release Activities, and Release Dose Rates (Continued) ${ }^{\dagger}$

\begin{tabular}{|c|c|c|c|c|c|c|c|c|c|c|c|}
\hline \multirow[b]{2}{*}{ Isotope } & \multirow[b]{2}{*}{$\begin{array}{c}\text { Half-Life } \\
\text { (days) }\end{array}$} & \multirow{2}{*}{$\begin{array}{c}\text { Intensity } \\
\text { (fraction/ } \\
\text { disintegration) }\end{array}$} & \multirow{2}{*}{\multicolumn{2}{|c|}{$\begin{array}{cc} & \begin{array}{c}\text { Linear Energy- } \\
\text { Absorption }\end{array} \\
\text { Energy }^{*} & \text { Coefficient } \\
(\mathrm{MeV}) & (\mathbf{1} / \mathrm{m}) \\
\end{array}$}} & \multirow[b]{2}{*}{$\begin{array}{c}\mathrm{MeV} / \mathrm{cm} / \\
\text { disintegration }\end{array}$} & \multicolumn{2}{|c|}{ Exposure Rate } & \multicolumn{3}{|c|}{$\begin{array}{l}\text { Release Activity Based On } \\
0.5 \text { rem to Total Decay }\end{array}$} & \multirow{2}{*}{$\begin{array}{l}\text { Release } \\
\text { Dose Rate- } \\
\text { at } 1 \text { Meter: } \\
\text { for } Q_{\circ} \\
\text { (mrem/hr) }\end{array}$} \\
\hline & & & & & & $\begin{array}{l}\text { R/Ci-hr } \\
\text { at } 1 \text { Meter }\end{array}$ & $\begin{array}{l}\mathrm{R} / \mathrm{mCi}-\mathrm{hr} \\
\text { at } 1 \mathrm{~cm}\end{array}$ & $\begin{array}{c}Q_{0} \\
\left(m C_{i}\right)\end{array}$ & $\begin{array}{c}\mathrm{Q}_{\mathrm{o}} \\
(\mathrm{MBq})\end{array}$ & $\overline{\mathrm{Q}_{\mathrm{o}}}$ & \\
\hline $\mathrm{Sn}-117 \mathrm{~m}$ & 13.61 & $\begin{array}{l}0.1873 \\
0.3514 \\
0.1185 \\
0.0211 \\
0.864\end{array}$ & $\begin{array}{l}0.025 \\
0.0253 \\
0.0285 \\
0.156 \\
0.1586\end{array}$ & $\begin{array}{l}3.35 \mathrm{E}-02 \\
3.30 \mathrm{E}-02 \\
2.25 \mathrm{E}-02 \\
3.25 \mathrm{E}-03 \\
3.30 \mathrm{E}-03\end{array}$ & $\begin{array}{l}1.57 \mathrm{E}-06 \\
2.93 \mathrm{E}-06 \\
7.60 \mathrm{E}-07 \\
1.07 \mathrm{E}-07 \\
4.52 \mathrm{E}-06\end{array}$ & $\begin{array}{l}2.35 \mathrm{E}-02 \\
4.40 \mathrm{E}-02 \\
1.14 \mathrm{E}-02 \\
1.60 \mathrm{E}-03 \\
6.78 \mathrm{E}-02\end{array}$ & $\begin{array}{l}2.35 \mathrm{E}-01 \\
4.40 \mathrm{E}-01 \\
1.14 \mathrm{E}-01 \\
1.60 \mathrm{E}-02 \\
6.78 \mathrm{E}-01\end{array}$ & (Occup & ancy Factor & $=0.25$ ) & \\
\hline \multicolumn{6}{|c|}{ Exposure Rate Constant (Total)* } & $1.48 \mathrm{E}-01$ & $1.48 \mathrm{E}+00$ & $2.87 \mathrm{E}+01$ & $1.06 \mathrm{E}+03$ & $1.06 \mathrm{E}+00$ & $4.25 \mathrm{E}+00$ \\
\hline Tc-99m & 0.251 & $\begin{array}{l}0.021021 \\
0.040194 \\
0.012059 \\
0.8907 \\
0.000214\end{array}$ & $\begin{array}{l}0.018251 \\
0.018367 \\
0.0206 \\
0.14051 \\
0.14263\end{array}$ & $\begin{array}{l}7.90 \mathrm{E}-02 \\
7.90 \mathrm{E}-02 \\
5.90 \mathrm{E}-02 \\
3.20 \mathrm{E}-03 \\
3.20 \mathrm{E}-03\end{array}$ & $\begin{array}{l}3.03 \mathrm{E}-07 \\
5.83 \mathrm{E}-07 \\
1.47 \mathrm{E}-07 \\
4.00 \mathrm{E}-06 \\
9.77 \mathrm{E}-10\end{array}$ & $\begin{array}{l}4.54 \mathrm{E}-03 \\
8.74 \mathrm{E}-03 \\
2.20 \mathrm{E}-03 \\
6.00 \mathrm{E}-02 \\
1.46 \mathrm{E}-05 \\
\end{array}$ & $\begin{array}{l}4.54 \mathrm{E}-02 \\
8.74 \mathrm{E}-02 \\
2.20 \mathrm{E}-02 \\
6.00 \mathrm{E}-01 \\
1.46 \mathrm{E}-04 \\
\end{array}$ & $\left(\mathrm{Occu}_{3}\right.$ & pancy Factor & $=1.0)$ & \\
\hline \multicolumn{6}{|c|}{ Exposure Rate Constant (Total)* } & $7.56 \mathrm{E}-02$ & $7.56 \mathrm{E}-01$ & $7.62 \mathrm{E}+02$ & $2.82 \mathrm{E}+04$ & $2.82 \mathrm{E}+01$ & $5.76 \mathrm{E}+01-$ \\
\hline T1-201 & 3.044 & $\begin{array}{l}0.0022 \\
0.27357 \\
0.46525 \\
0.20465 \\
0.0265 \\
0.0016 \\
0.1\end{array}$ & $\begin{array}{l}0.0306 \\
0.068895 \\
0.070819 \\
0.0803 \\
0.13534 \\
0.16588 \\
0.16743\end{array}$ & $\begin{array}{l}1.80 \mathrm{E}-02 \\
3.45 \mathrm{E}-03 \\
3.40 \mathrm{E}-03 \\
3.20 \mathrm{E}-03 \\
3.20 \mathrm{E}-03 \\
3.30 \mathrm{E}-03 \\
3.30 \mathrm{E}-03\end{array}$ & $\begin{array}{l}1.21 \mathrm{E}-08 \\
6.50 \mathrm{E}-07 \\
1.12 \mathrm{E}-06 \\
5.26 \mathrm{E}-07 \\
1.15 \mathrm{E}-07 \\
8.76 \mathrm{E}-09 \\
5.53 \mathrm{E}-07\end{array}$ & $\begin{array}{l}1.82 E-04 \\
9.75 E-03 \\
1.68 E-02 \\
7.88 E-03 \\
1.72 E-03 \\
1.31 E-04 \\
8.28 E-03\end{array}$ & $\begin{array}{l}1.82 \mathrm{E}-03 \\
9.75 \mathrm{E}-02 \\
1.68 \mathrm{E}-01 \\
7.88 \mathrm{E}-02 \\
1.72 \mathrm{E}-02 \\
1.31 \mathrm{E}-03 \\
8.28 \mathrm{E}-02\end{array}$ & \multicolumn{3}{|c|}{ (Occupancy Factor $=0.25)$} & \\
\hline \multicolumn{6}{|c|}{ Exposure Rate Constant (Total)* } & $4.47 \mathrm{E}-02$ & $4.47 \mathrm{E}-01$ & $4.25 \mathrm{E}+02$ & $1.57 \mathrm{E}+04$ & $1.57 \mathrm{E}+01$ & $1.90 \mathrm{E}+01$ \\
\hline
\end{tabular}


Table A.2 Exposure Rate Constants, Release Activities, and Release Dose Rates (Continued) ${ }^{\dagger}$

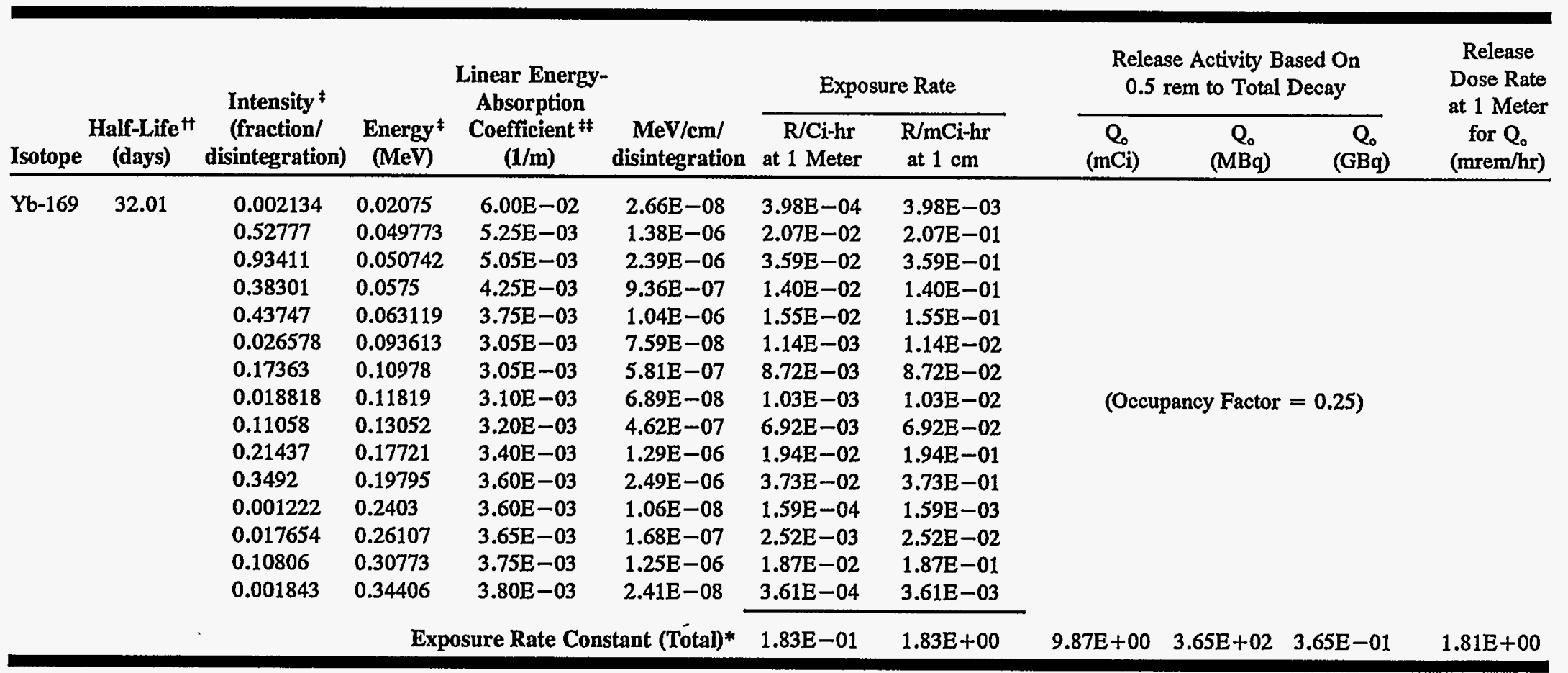

\footnotetext{
† Values shown for the exposure rate constant, release activity, and release dose rate for each isotope are based on a bare point source, no shielding considered.

\# K.F. Eckerman, A.B. Wolbarst, and A.C.B. Richardson, "Federal Guidance Report No. 11, Limiting Values of Radionuclide Intake and Air Concentration and Dose Conversion Factors for Inhalation, Submersion, and Ingestion," Report No. EPA-520/1-88-020, Office of Radiation Programs, U.S. Environmental
} Protection Agency, Washington, DC, 1988.

* Values for the intensity and energy for Ag-111, Ga-67, I-125, Sm-153, Tc-99m, T1-201, and Yb-169 were taken from: Bernard Shleien, The Health Physics and Radiological Health Handbook, Revised Edition, Scinta, Inc., 1992, pages 294-334. For Sn-117m, the values for intensity and energy were

taken from: L.M. Unger and D.K. Trubey, "Specific Gamma-Ray Dose Constants for Nuclides Important to Dosimetry and Radiological Assessment," U.S. Department of Energy, ORNL/RSIC-45/R1, 1982. For Pd-103, the values for intensity and energy were taken: A.S. Meigooni and R. Nath, "A Comparision of Radial Dose Functions for ${ }^{103} \mathrm{Pd},{ }^{125} \mathrm{I},{ }^{145} \mathrm{Sm},{ }^{241} \mathrm{Am},{ }^{169} \mathrm{Yb},{ }^{192} \mathrm{Ir}$, and ${ }^{137} \mathrm{Cs}$ Brachytherapy Sources, "International Journal of Radiation Oncology-BiologyPhysics, Volume 22, Number 5, 1992.

¥ Values for the linear energy-absorption coefficient in air were taken from: Radiologcal Health Handbook, U.S. Department of Health, Education, and Welfare, page 135, 1970. 
* The exposure rate constant was calculated because the published value for this isotope was an approximate value, presented as a range of values, or it varied from one reference to another. Only gamma rays and X-rays with energies above $11.3 \mathrm{keV}$ were used to calculate the exposure rate factor. The $11.3 \mathrm{keV}$

cutoff is the one used in NCRP Report No. 41, "Specification of Gamma-Ray Brachytherapy Sources," 1974. The exposure rate constant was calculated by using the following equation:

$$
\Gamma \frac{\mathrm{mR} \cdot \mathrm{cm}^{2}}{\mathrm{mCi} \cdot \mathrm{hr}}=\left(1.332 \times 10^{14} \frac{\mathrm{dis}}{\mathrm{mCi} \cdot \mathrm{hr}}\right)\left(\frac{1}{4 \pi(100 \mathrm{~cm})^{2}}\right) \sum \mathrm{f}_{\mathrm{i}} \mathrm{E}_{\mathrm{i}}\left(\frac{\mu_{\mathrm{a,i}} \mathrm{cm}^{-1}}{\rho \mathrm{gm} \cdot \mathrm{cm}^{-3}}\right)\left(\frac{\mathrm{gm} \cdot \mathrm{mR}}{87.6 \mathrm{erg}}\right)\left(1.6 \times 10^{-6} \frac{\mathrm{erg}}{\mathrm{MeV}}\right)
$$

Where $E_{i}=$ the energy of the $i$ th gamma ray or X-ray $i, M e V$

$f_{i}=$ the probability of decay (i.e., intensity) of gamma rays or $X$-rays with energy $E_{1}$ per disintegration.

$\mu_{a, i}=$ the linear energy absorption coefficient in air of photons of energy $E_{1}$.

$\rho=$ the density of air at standard temperature and pressure, taken to be $0.0012929 \mathrm{gm} / \mathrm{cm}^{3}$.

** Radiologcal Health Handbook, U.S. Department of Health, Education, and Welfare, 1970.

*** D.E. Barber, J.W. Baum, and C.B. Meinhold, "Radiation Safety Issues Related to Radiolabeled Antibodies, " NUREG/CR-4444, U.S. Nuclear Regulatory Commission, Washigton, DC, 1991. 


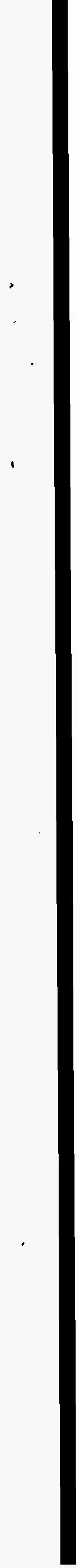




\section{APPENDIX B}

\section{PARAMETERS AND CALCULATIONS FOR DETERMINING INSTRUCTIONS TO PATIENTS WHO ARE BREAST-FEEDING*}

\section{B.1 CALCULATIONAL METHOD}

The breast milk concentration of a radiopharmaceutical as a function of time $C(t)$, (i.e., the activity per milliliter of breast milk) was calculated from the equation,

$$
C(t)=A \alpha \exp \left(-\left(\lambda+\lambda_{p}\right)(t-3)\right)
$$

where $A=$ the activity administered to the woman,

$$
\begin{aligned}
\alpha= & \text { maximum fraction of administered } \\
& \text { activity (per milliliter of breast milk), } \\
\lambda= & \text { biological decay constant } \\
\lambda_{p}= & \text { physical decay constant, } \\
t= & \text { time at which breast-feeding occurs. }
\end{aligned}
$$

A comprehensive search of the medical literature was performed in early 1995 . From the data gathered from the literature, the highest concentration (or highest fraction) $\alpha_{2}$ of a radiopharmaceutical in the breast milk post administration to the women and the longest biological half-life $T_{b 2}$ (not necessarily from the same study) were chosen to represent the worst case scenario, and the lowest concentration (or lowest fraction) $\alpha_{1}$ and shortest biological half-life $T_{b 1}$ were chosen to represent the best case scenario. Breast milk concentrations reported in the literature were first corrected for radioactive decay to the time of administration (unless the article explicitly stated that such a correction had already been made). Then, this maximum concentration was assumed to occur at 3 hours post administration. It might have been more conservative to extrapolate this back from the time at which the concentration was observed to 3 hours post administration, but in many cases, only one value was reported and a biological half-life was not available. If concentrations were reported at times less than 3 hours, the highest concentration reported was used without correction for biological removal, and assumed to occur at 3 hours post administration.

A computer program was written which used Equation B.1 describing breast milk concentration as a function of time represented by each scenario to estimate the fraction of the activity administered to the woman which would be excreted in the breast milk and ingested by the infant. The program assumed that the infant would resume feeding at 3 hours post administration and would then nurse every 3 hours thereafter (i.e., 8 feedings per day), consuming 125 milliliters of milk per feeding (this represents a daily average consumption of 1,000 milliliters). Thus, the program calculated the breast milk concentration (in units of fraction of administered activity per milliliter of milk) at 3 hour intervals based on the excretion functions observed, multiplied by 125 milliliters to estimate the total fraction ingested at that feeding, and added up a total fractional absorption over all feedings (summations were carried out to 50 effective half-lives). The program also calculated cumulative ingestion for assumed interruption periods of 12 hours ( 0.5 day) 24 hours ( 1 day), 48 hours ( 2 days), 96 hours (4 days), 120 hours (5 days), 168 hours ( 7 days), 336 hours (14 days), and 672 hours ( 28 days). For example, if the interruption time was 24 hours, the first calculation would have been for $t=24$, followed by 27 hours, 30 hours, and so on. There is no information in the literature describing

*Information in this appendix was provided by R.E. Toohey, M.G. Stabin, and J. Stubbs, Radiation Internal Dose Information Center (RIDIC), Oak Ridge Institute for Science and Education, Oak Ridge, TN. 
uptake of ingested radiopharmaceuticals from the infant gastrointestinal (GI) tract, thus it was assumed that 100 percent of the ingested activity was quickly and completely absorbed from the infant's GI tract.

Radiation doses for newborns ( $3.4 \mathrm{~kg}$ ) and oneyear-olds $(9.8 \mathrm{~kg})$, based on the mathematical phantoms of Cristy and Eckerman (CR87) have been estimated for the radiopharmaceuticals considered in this analysis and compiled in a reference on pediatric radiation dosimetry in nuclear medicine (ST95). These dose estimates generally apply to intravenous administration of these pharmaceuticals. The dose estimates are expressed as effective dose equivalents (EDE) per unit ingested activity; a summary of the values used are given in Table B.1. (Some dose estimates, based on more recent models were supplied by the Radiation Internal Dose Information Center, Oak Ridge, TN.) Typical values of activity administered to the woman per procedure were taken from various sources, to estimate the total internal dose to the infant from a typical procedure. There are certainly cases, most notably for therapeutic administrations of iodine-131 sodium iodide, in which the effective dose equivalent should not be used for decision making, and the individual organ absorbed doses should be considered.

The computer program estimated the intake and subsequent dose to newborns and one-year-olds for both the best and worst case scenarios, for no interruption (first feeding 3 hours after administration to the woman), and for the various interruption schedules described above.

An upper limit of 0.50 was placed on the total fraction of administered activity which could be excreted over all time in the breast milk. It was possible for unrealistic values (e.g., fractions greater than 1.0) to be calculated by merely permitting the computer program to sum the product of the fraction of activity per milliliter and 125 milliliter per feeding for a large number of feedings. Thus, it was thought that an upper limit of 0.50 should be placed on this value, which represents excretion through the breast milk pathway competing equally with all other excretion pathways available. This value is also compatible with the highest fraction reported for total excretion of any radiopharmaceutical, namely a fraction of 0.33 for iodine- 131 sodium iodide
(MO89a). This is probably a conservative upper limit in most cases. In those cases in which a literature reference gave only the cumulative fraction of activity excreted in the breast milk over the course of the study, the fraction of injected activity excreted per milliliter of milk at different times was not available (although a clearance half-life may have been reported). A single value of cumulative excretion could not be used in this analysis, as it most likely represented the cumulative fraction excreted assuming no interruption of breast-feeding, and therefore could not be used directly to infer the cumulative fraction under different interruption schedules. To estimate the cumulative fraction under different interruption schedules, it was necessary to calculate the time-dependent behavior of the clearance. Thus, a breast milk concentration at early times was estimated which would result in a cumulative excretion equal to the value reported assuming no interruption of breast-feeding, the clearance half-life reported by the authors, and using the nursing schedule and volume assumed in this analysis. This derived early concentration was then used in the computer program with the clearance half-life chosen to estimate the cumulative fraction ingested under different interruption schedules.

None of the analyses for the iodine compounds included any considerations for free iodide in the pharmaceutical product, while the other analyses did not include considerations for possible radioactive contaminants (except for the three cases discussed below) or breakthrough products. These additional components of the dose are usually very small. Also, the assignment of numerical values to these quantities (the fraction of free iodide, percent activity of contaminants, etc.) would be arbitrary, as these values vary considerably between products, and even with time.

However, the presence of possible radioactive contaminants in some of the pharmaceutical products was considered. The cases considered were: (1) indium-114m and indium-114 contaminants in indium-111 products, (2) iodine-125 contaminant in iodine-123 products, and (3) thallium-200 and thallium-202

contaminants in thallium-201 chloride. Finding published information about the possible levels of these contaminants likely to be found in the products was difficult. The most common source 
of these data is the radiopharmaceutical package inserts. Discussion with some industry experts, however, indicated that the levels listed in most of these inserts may considerably overestimate actual levels encountered in current practice. Therefore, the levels adopted for this analysis were those gathered as a consensus of some experts in measuring these quantities. The values used were: (1) indium-114m and indium-114 0.25 percent, (2) iodine- $125-0.01$ percent, and (3) thallium-200 - 0.3 percent and thallium-202 1.2 percent. Although the additional dose from these contaminants is included in the values in Table B-4, the number of millicuries of activity and the percent of administered activity ingested by the infant in that table reflects only the contribution from the main radiopharmaceutical.

\section{B.2 RESULTS}

This analyses covers 25 of the radiopharmaceuticals most commonly used in nuclear medicine procedures involving women who are breast-feeding an infant.

\section{B.2.1 Biokinetic Data for Excretion of Radiopharmacueticals in Breast Milk}

The data obtained from the literature review are summarized in Table B.2. The biokinetic data for each radiopharmaceutical excreted in breast milk are given in Table B.2 as the excretion fraction, per unit volume of breast milk, the biological half-life for excretion, time of peak concentration (when data were reported as concentration rather than cumulative excretion fraction), and the reference. Most papers reported an effective half-life for excretion of radiopharmaceuticals in breast milk and these values were converted to biological half-lives. Several values of the reported effective half-life for excretion were larger than the physical half-life of the radionuclide (e.g., $T_{e f f}=9$ hours for Technetium-99m RBCs (RU94)) indicating continued accumulation in the breast milk of the radiopharmaceutical over time. These values are denoted in the table in parentheses. Several publications reported cumulative excretion fractions (denoted by the symbol $\S$ ) and these values were used to estimate the concentrations of the radiopharmaceutical in breast milk as described above (see Section B.1 CALCULATIONAL METHOD). When data for a single subject were reported, the reported/derived value of excretion fraction per milliliter of breast milk was considered to be "highest", for that publication, and no "lowest" value was listed. In some cases, the breast milk peak concentration was estimated from graphical information in an article; these estimates are shown with a " " symbol.

Robinson et al. (RO94) reported a concentration and excretion half-life for a diagnostic dose of iodine-131 sodium iodide and also reported that the same patient exhibited biphasic excretion of the iodine-131 administered in a therapeutic study. Murphy et al. (MU89) reported that thallium-201 chloride exhibited biphasic clearance. All other radiopharmaceuticals seemed to follow monophasic clearance patterns, except for two case studies involving iodine- 131 sodium iodide. This radiopharmaceutical was nonetheless modeled with a monophasic clearance pattern for the purposes of this study.

Table B.3 lists the biological and physical parameters used by the computer program to calculate the total activity ingested and the internal radiation doses received from the intake of radiopharmaceuticals in breast milk for newborns and one-year-olds.

\section{B.2.2 Radiation Dose Estimates}

Table B.4 lists the dose estimates for the 25 radiopharmaceuticals analyzed, for both the newborn and the one-year-old, for both best and worst case scenarios, and for all interruption schedules. Note, that in the case of iodine-131 sodium iodide the infant thyroid doses, instead of effective dose equivalents, were shown, due to the high doses predicted. Table B.5 shows the summary of recommendations for the radiopharmaceuticals considered in this analysis, showing the maximum administered activities assumed, the internal dose to the infant if no interruption of breast-feeding is assumed, whether or not instructions are required, the external dose from radiation during breast-feeding assuming interruption, and the recommendation on interruption of breast-feeding (which includes adjustment for the external dose during breast-feeding). 
Table B.1 Effective Dose Equivalents to Newborns and One-Year-Olds from Infant's Intake of Radiopharmaceuticals

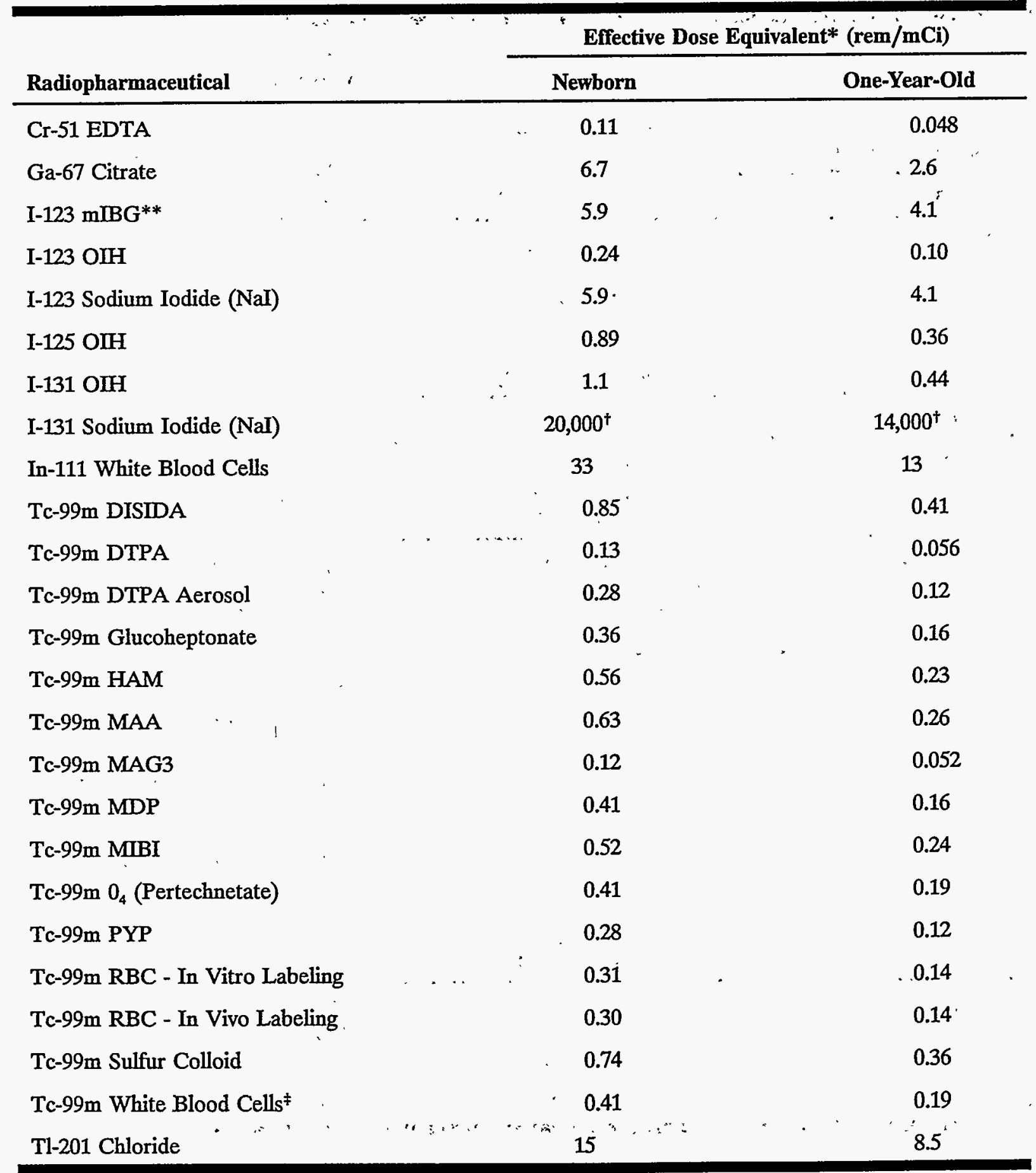

* Effective dose equivalent to the infant per unit activity administered intravenously to the infant (except in the case of Tc-99m DTPA Aerosol).

** Specification tests indicated that the activity was most likely in the form of NaI, not mIBG. Thus, the dose estimate for I-123 mIBG is that shown for I-123 NaI.

t Dose to the infant's thyroid per unit activity administered intravenously (or orally) to the infant ( $\mathrm{rad} / \mathrm{mCi}$ ).

\# The values shown are actually the dose estimates for $\mathrm{Tc}-99 \mathrm{~m}$ pertechnetate, as it was assumed that activity released in breast milk from this product would be in the form of pertechnetate. 
Table B.2 Excretion Fractions and Biological Half-Lives for Radiopharmaceuticals Excreted in Breast Milk

\begin{tabular}{|c|c|c|c|}
\hline Radiopharmaceutical & $\begin{array}{c}\text { Measured } \\
\text { Excretion Fractions* } \\
\alpha \boldsymbol{\alpha}\end{array}$ & $\begin{array}{l}\text { Biological } \\
\text { Half-Life } \\
\text { for } \\
\text { Excretion } \\
T_{b}(\mathrm{hr})\end{array}$ & Reference \\
\hline Cr-51 EDTA & $1.5 E-4 \S \S-6.5 E-4 \S \S$ & $5.0-7.0$ & AH85 \\
\hline Ga-67 Citrate & $\begin{array}{c}9.5 \mathrm{E}-5(72) \\
2.7 \mathrm{E}-5(38)-3.7 \mathrm{E}-5(58) \\
5.6 \mathrm{E}-5(96) \\
1.0 \mathrm{E}-4(88) \\
4.3 \mathrm{E}-5(48) \\
3.16 \mathrm{E}-2 \S \S-9.9 \mathrm{E}-2 \S \S\end{array}$ & $\begin{array}{c}216 \\
82-385\end{array}$ & $\begin{array}{l}\text { TO76 } \\
\text { RU94 } \\
\text { LA71 } \\
\text { GR83 } \\
\text { WE94 } \\
\text { RU94 }\end{array}$ \\
\hline I-123 mIBG $\star$ & $7.2 \mathrm{E}-6(8)$ & 85 & KE94 \\
\hline I-123 OIH & $\begin{array}{c}6.0 \mathrm{E}-5 \\
1.2 \mathrm{E}-02 \S \S-3.5 \mathrm{E}-2 \S \S \\
1.5 \mathrm{E}-4(4)\end{array}$ & $\begin{array}{c}4.8 \\
8.1-10.2 \\
8.3\end{array}$ & $\begin{array}{l}\text { MO89b } \\
\text { RO90 } \\
\text { RO90 }\end{array}$ \\
\hline I-123 Sodiun Iodide (NaI) & $\begin{array}{l}2.6 \mathrm{E}-2 \S \S \\
6.5 \mathrm{E}-5\end{array}$ & $\begin{array}{l}10.4 \\
10.4\end{array}$ & $\begin{array}{l}\text { HE86 } \\
\text { HE86 }\end{array}$ \\
\hline I-125 OIH & $2.4 \mathrm{E}-2 \S \S$ & 4.8 & AH85 \\
\hline I-131 OIH & $1.8 \mathrm{E}-2 \S \S-4.9 \mathrm{E}-2 \S \S$ & $2.2-6.0$ & AH85 \\
\hline I-131 Sodiun Iodide (NaI) & $\begin{array}{c}1.4 \mathrm{E}-5(24)-4.0 \mathrm{E}-5(6) \\
6.7 \mathrm{E}-4(6) \\
6.6 \mathrm{E}-4 \\
1.6 \mathrm{E}-5 \\
3.0 \mathrm{E}-2(18) \\
\sim 5.0 \mathrm{E}-4 \\
\\
\\
2.3 \mathrm{E}-1 \S \S \\
2.5 \mathrm{E}-1 \S \S-4.6 \mathrm{E}-1 \S \S \\
\end{array}$ & $\begin{array}{c}\sim 9.9 \\
12 \\
526 \\
\sim 9.4 \\
13 \\
11 \\
235 \\
117 \\
7.6-12 \\
\end{array}$ & $\begin{array}{l}\text { NU52 } \\
\text { WE60 } \\
\text { DY88 ( } 2 \text { comp } \\
\text { model) } \\
\text { RU88 } \\
\text { RO94 (diag.) } \\
\text { RO94 (ther. } \\
2 \text { comp model) } \\
\text { RU94 } \\
\text { MO89a } \\
\end{array}$ \\
\hline In-111 White Blood Cells & $\begin{array}{l}3.3 \mathrm{E}-7(13) \\
7.3 \mathrm{E}-7(16) \\
2.4 \mathrm{E}-7(20) \\
\end{array}$ & $\begin{array}{l}(85.3) \dagger \dagger \\
(140)+\dagger\end{array}$ & $\begin{array}{l}\text { MO85 } \\
\text { HE88 } \\
\text { BU86 } \\
\end{array}$ \\
\hline Tc-99m DISIDA & $1.0 \mathrm{E}-3 \S \S-2.8 \mathrm{E}-3 \S \S$ & $10-(9.1)+\dagger$ & RU94 \\
\hline
\end{tabular}


Table B.2 Excretion Fractions and Biological Half-Lives for Radiopharmaceuticals Excreted in Breast Milk (Continued)

\begin{tabular}{|c|c|c|c|}
\hline Radiopharmaceutical & $\begin{array}{c}\text { Measured } \\
\text { Excretion Fractions* } \\
\alpha \boldsymbol{\alpha} \\
\end{array}$ & $\begin{array}{l}\text { Biological } \\
\text { Half-Life } \\
\quad \text { for } \\
\text { Excretion } \\
T_{b} \text { (hr) }\end{array}$ & Reference \\
\hline Tc-99m DTPA & $\begin{array}{l}7.2 \mathrm{E}-7(2.2) \\
6.0 \mathrm{E}-7(2.8) \\
5.0 \mathrm{E}-4 \S \S-2.4 \mathrm{E}-3 \S \S \\
\sim 5.0 \mathrm{E}-7(\sim 3)\end{array}$ & $\begin{array}{l}15 \\
15 \\
6.5-30 \\
9.6\end{array}$ & $\begin{array}{l}\text { MO84 } \\
\text { MO85 } \\
\text { RU94 } \\
\text { AH85 }\end{array}$ \\
\hline Tc-99m DTPA Aerosol & \multicolumn{3}{|c|}{$\begin{array}{l}\text { Fraction of administered aerosol assumed to reach bloodstream } \\
(0.406) \text { treated as Tc-99m DTPA. }\end{array}$} \\
\hline Tc-99m Glucoheptonate & $\begin{array}{l}1.4 \mathrm{E}-3 \S \S \\
2.6 \mathrm{E}-6\end{array}$ & $\ldots \begin{array}{l}9.0 \\
12\end{array}$ & $\begin{array}{l}\text { RU94 } \\
\text { MO87 }\end{array}$ \\
\hline Tc-99m HAM & $8.8 \mathrm{E}-3 \S \S-1.1 \mathrm{E}-2 \S \S$ & $6.0-(7.0) \dagger \dagger$ & RU94 \\
\hline Tc-99m MAA & $\begin{array}{c}1.4 \mathrm{E}-4(2.2) \\
7.1 \mathrm{E}-6(5)-3.1 \mathrm{E}-4(7) \\
2.4 \mathrm{E}-5(4) \\
1.4 \mathrm{E}-4(3.5) \\
7.0 \mathrm{E}-6(6) \\
4.0 \mathrm{E}-3 \S \S-5.2 \mathrm{E}-2 \S \S\end{array}$ & $\begin{array}{c}20 \\
5.2-45 \\
5.3 \\
12^{* *} \\
\sim 12 \\
7.3-18\end{array}$ & $\begin{array}{l}\text { MO84 } \\
\text { MA81 } \\
\text { BE73 } \\
\text { CR85 } \\
\text { HE79 } \\
\text { AH85 }\end{array}$ \\
\hline Tc-99m MAG3 & \multicolumn{3}{|c|}{ Treated as Tc-99m DTPA (renal agent for which data exist). } \\
\hline Tc-99m MDP/HDP & $\sim 1.6 \mathrm{E}-6(\sim 4)$ & 8.4-34 & AH85 \\
\hline Tc-99m MIBI & $\begin{array}{c}1.4 \mathrm{E}-6(3.3) \\
1.0 \mathrm{E}-4 \S \S-3.0 \mathrm{E}-4 \S \S\end{array}$ & $\begin{array}{c}23 \\
18-(6.7)+\dagger \\
\end{array}$ & $\begin{array}{l}\text { RU91§ } \\
\text { RU94 }\end{array}$ \\
\hline Tc-99m $0_{4}$ (Pertechnetate) & $\begin{array}{c}\sim 6.7 \mathrm{E}-6(8.5) \\
2.6 \mathrm{E}-5(10)-6.4 \mathrm{E}-5(2) \\
1.4 \mathrm{E}-4(22) \\
\sim 1.3 \mathrm{E}-5(3) \\
7.19 \mathrm{E}-3(2.4)-1.7 \mathrm{E}-2(2) \\
\sim 5.0 \mathrm{E}-4(\sim 5) \\
1.7 \mathrm{E}-4(8.2) \\
1.4 \mathrm{E}-4(\sim 3)\end{array}$ & $\begin{array}{c}6.9 \\
6 \\
5.2 \\
\end{array}$ & $\begin{array}{l}\text { RU78 } \\
\text { WY73 } \\
\text { VA71 } \\
\text { PI79 } \\
\text { OG83† } \\
\text { AH85 } \\
\text { MO87 } \\
\text { HE86 } \\
\end{array}$ \\
\hline Tc-99m PYP & $1.5 \mathrm{E}-3 \S \S-4.4 \mathrm{E}-3 \S \S$ & $8.4-(6.8) \div \dagger$ & RU94 \\
\hline $\begin{array}{l}\text { Tc-99m RBC- } \\
\text { In Vitro Labeling }\end{array}$ & $2.0 \mathrm{E}-4 \S \S-3.0 \mathrm{E}-4 \S \S$ & $(7.8-9.0) \div \dagger$ & RU94 \\
\hline
\end{tabular}


Table B.2 Excretion Fractions and Biological Half-Lives for Radiopharmaceuticals Excreted in Breast Milk (Continued)

\begin{tabular}{|c|c|c|c|}
\hline Radiopharmaceutical & $\begin{array}{c}\text { Measured } \\
\text { Excretion Fractions* }\end{array}$ & $\begin{array}{c}\text { Biological } \\
\text { Half-Life } \\
\text { for } \\
\text { Excretion } \\
T_{b}(\mathrm{hr})\end{array}$ & Reference \\
\hline $\begin{array}{l}\text { Tc-99m RBC - } \\
\text { In Vivo Labeling }\end{array}$ & $\begin{array}{c}6.0 \mathrm{E}-3 \S \S-1.0 \mathrm{E}-2 \S \S \\
4.5 \mathrm{E}-5(8) \\
\sim 1.0 \mathrm{E}-7(\sim 4)\end{array}$ & $\begin{array}{l}(7.7) \dagger \dagger \\
(6.8) \dagger \dagger \\
(7) \dagger \dagger\end{array}$ & $\begin{array}{l}\text { RO90 } \\
\text { RO90 } \\
\text { AH85 }\end{array}$ \\
\hline Tc-99m Sulphur Colloid & $1.6 \mathrm{E}-3 \S \S-1.5 \mathrm{E}-2 \S \S$ & $35-(8.3)+\dagger$ & RU94 \\
\hline Tc-99m White Blood Cells & \multicolumn{3}{|c|}{$\begin{array}{l}\text { Treated as Tc- }-99 \mathrm{~m} \text { pertechnetate, as fraction of free } \mathrm{Tc}-99 \mathrm{~m} \text { is } \\
\text { highly variable. }\end{array}$} \\
\hline Tl-201 Chloride & $\begin{array}{l}2.2 \mathrm{E}-6 \\
1.9 \mathrm{E}-7 \\
1.7 \mathrm{E}-6 \\
9.5 \mathrm{E}-7\end{array}$ & $\begin{array}{c}43 \\
(362) \dagger \dagger \\
13 \\
164\end{array}$ & $\begin{array}{l}\text { MU89 (2 com- } \\
\text { partment model) } \\
\text { JO95 ( } 2 \text { com- } \\
\text { partment model) }\end{array}$ \\
\hline
\end{tabular}

Xe-133 Gas

Insignificant Dose to the breast-feeding infant.

* Peak fraction per milliliter of milk. All values corrected to the time of activity administration. The number in parenthesis is the time (hr) at which this maximum was observed. If data from more than one patient are reported, data are presented as a range.

** Pooled data from 4 patients.

$\dagger$ Patient admitted for study of enlarged thyroid.

\# Conservative value chosen due to anecdotal report $(n=1)$ (see addendum of MO84).

8 Data in Table 1 of RU91 recalculated due to possible errors in derived values for the percent excreted in milk.

88 Total fraction excreted - milk concentrations not given.

If For some radiopharmacueticals, $T_{b}$ may be negative (i.e., values shown in parentheses) because these were the unusual cases reported in the literature in which the effective half-life was greater than the radionuclide's physical half-life (i.e., $T_{d f}>T_{p}$ indicates continued activity accumulation).

$\star$ Speciation tests indicated that the activity excreted was most likely in the form of NaI, not mIBG. 
Table B.3 Biological and Physical Parameters Used to Calculate the Total Activity Ingested and Internal Radiation Doses Received from the Intake of Radiopharmaceuticals in Breast Milk

\begin{tabular}{|c|c|c|c|c|c|}
\hline \multirow[b]{2}{*}{ Radiopharmaceutical } & \multirow{2}{*}{$\begin{array}{l}\text { Administered } \\
\text { Activity } \\
\text { (mCi) }\end{array}$} & \multicolumn{2}{|c|}{ Excretion Fraction* } & \multicolumn{2}{|c|}{$\begin{array}{l}\text { Biological Half-Life } \\
\text { for Excretion*** }\end{array}$} \\
\hline & & $\begin{array}{c}\text { Lowest } \\
\alpha_{1}\end{array}$ & $\begin{array}{c}\text { Highest } \\
\alpha_{2}\end{array}$ & $\begin{array}{c}\text { Shortest } \\
T_{b 1} \text { (hr) }\end{array}$ & $\begin{array}{l}\text { Longest } \\
T_{b 2} \text { (hr) }\end{array}$ \\
\hline Cr-51 EDTA & 0.05 & $3.2 \mathrm{E}-7$ & $1.4 \mathrm{E}-6$ & 5 & 7 \\
\hline Ga-67 Citrate & 5 & $8.0 \mathrm{E}-6$ & $1.0 \mathrm{E}-4$ & 20 & 390 \\
\hline I-123 mIBG & 10 & $7.2 \mathrm{E}-6$ & $7.2 \mathrm{E}-6$ & 85 & 85 \\
\hline I-123 OIH & 2 & $2.9 \mathrm{E}-5$ & $1.5 \mathrm{E}-4$ & 4.8 & 10.2 \\
\hline I-123 Sodium Iodide (NaI) & 0.4 & $6.2 \mathrm{E}-5$ & $6.5 \mathrm{E}-5$ & 10.4 & 10.4 \\
\hline I-125 OIH & 0.01 & 7.1E-5 & $7.1 \mathrm{E}-5$ & 4.8 & 4.8 \\
\hline I-131 OIH & 0.3 & 4.3E-5 & $1.2 \mathrm{E}-4$ & 2.2 & 6.0 \\
\hline I-131 Sodium Iodide (NaI) & 150 & $1.4 \mathrm{E}-5$ & $6.7 \mathrm{E}-4$ & 7.6 & 117 \\
\hline In-111 White Blood Cells & 0.5 & $2.4 \mathrm{E}-7$ & $7.3 \mathrm{E}-7$ & $(85)$ & $(140)$ \\
\hline Tc-99m DISIDA & 8 & $3.4 \mathrm{E}-6$ & $4.6 \mathrm{E}-6$ & 10 & (9.1) \\
\hline Tc-99m DTPA & 20 & $5.0 \mathrm{E}-7$ & $6.5 \mathrm{E}-6$ & 6.5 & 30 \\
\hline Tc-99m DTPA Aerosol & 1 & 2.0E-7 & $2.7 \mathrm{E}-6$ & 6.5 & 30 \\
\hline Tc-99m Glucoheptonate & 20 & $2.6 \mathrm{E}-6$ & $4.9 \mathrm{E}-6$ & 9 & 12 \\
\hline Tc-99m HAM & 8 & $1.8 \mathrm{E}-5$ & $2.3 \mathrm{E}-5$ & 6 & $(7)$ \\
\hline Tc-99m MAA & 4 & $7.0 \mathrm{E}-6$ & 3.1E-4 & 5.2 & 45 \\
\hline Tc-99m MAG3 & 10 & $5.0 \mathrm{E}-7$ & $6.5 \mathrm{E}-6$ & 6.5 & 30 \\
\hline Tc-99m MDP & 20 & $1.6 \mathrm{E}-6$ & $1.6 \mathrm{E}-6$ & 8.4 & 34 \\
\hline Tc-99m MIBI & 30 & 2.2E-7 & $1.4 \mathrm{E}-6$ & 18 & $(6.7)$ \\
\hline Tc-99 $\mathrm{m} \mathrm{O}_{4}$ (Pertechnetate) & 30 & $6.7 \mathrm{E}-6$ & $1.7 \mathrm{E}-4$ & 5.2 & 66 \\
\hline Tc-99m PYP & 20 & $3.1 \mathrm{E}-6$ & $9.2 \mathrm{E}-6$ & 8.4 & $(6.8)$ \\
\hline Tc-99m RBC - In Vitro Labeling & 20 & 3.3E-7 & $5.0 \mathrm{E}-7$ & $(7.8)$ & (9) \\
\hline Tc-99m RBC - In Vivo Labeling & 20 & $1.0 \mathrm{E}-7$ & $4.5 \mathrm{E}-5$ & $(6.8)$ & $(7)$ \\
\hline
\end{tabular}


Table B.3 Biological and Physical Parameters Used to Calculate the Total Activity Ingested and Internal Radiation Doses Received from the Intake of Radiopharmaceuticals in Breast Milk (Continued)

\begin{tabular}{|c|c|c|c|c|c|}
\hline \multirow[b]{2}{*}{ Radiopharmaceutical } & \multirow{2}{*}{$\begin{array}{l}\text { Administered } \\
\text { Activity } \\
\text { (mCi) }\end{array}$} & \multicolumn{2}{|c|}{ Excretion Fraction* } & \multicolumn{2}{|c|}{$\begin{array}{l}\text { Biological Half-Life } \\
\text { for Excretion** }\end{array}$} \\
\hline & & $\begin{array}{c}\text { Lowest } \\
\qquad \alpha_{1}\end{array}$ & $\begin{array}{c}\text { Highest } \\
\alpha_{2}\end{array}$ & $\begin{array}{c}\text { Shortest } \\
T_{b 1}(h r)\end{array}$ & $\begin{array}{l}\text { Longest } \\
T_{b 2}(\mathrm{hr})\end{array}$ \\
\hline Tc-99m Sulfur Colloid & 12 & $2.8 \mathrm{E}-6$ & $2.6 \mathrm{E}-5$ & 35 & (8.3) \\
\hline Tc-99m White Blood Cells & 30 & $6.7 \mathrm{E}-6$ & $1.7 \mathrm{E}-4$ & 5.2 & 66 \\
\hline Tl-201 Chloride & 3 & $\begin{array}{l}1.7 \mathrm{E}-6 \\
9.5 \mathrm{E}-7\end{array}$ & $\begin{array}{l}2.2 \mathrm{E}-6 \\
1.9 \mathrm{E}-7\end{array}$ & $\begin{array}{l}13 \\
43\end{array}$ & $\begin{array}{c}43 \\
(362)\end{array}$ \\
\hline
\end{tabular}

* "Lowest" and "Highest" in this table refer to the lowest and highest concentration observed at peak for a given radiopharmaceutical by any author (see Table B.2 for references). These are combined with the shortest and longest biological half-lives for that radiopharmaceutical reported by any author. A given concentration and half-life combined to produce a supposedly best case or worst case scenario did not necessarily come from the same study.

** For some radiopharmacueticals, $T_{b 1}$ and/or $T_{b 2}$ may be negative (i.e., values shown in parentheses) because these were the unusual cases reported in the literature in which the effective half-life was greater than the radionuclide's physical half-life (i.e., $T_{d f}>T_{p}$ indicates continued activity accumulation). In these cases, the effective half-life was used to perform the analysis. 
Table B.4 Total Activity Ingested and Internal Radiation Doses Received from the Intake of Radiopharmaceuticals in Breast Milk Under Different Interruption Schedules

\begin{tabular}{|c|c|c|c|c|c|c|c|}
\hline \multirow{2}{*}{$\begin{array}{l}\text { Radio- } \\
\text { pharmaceutical }\end{array}$} & \multirow{2}{*}{$\begin{array}{c}\text { Administered } \\
\text { Activity } \\
\text { (mCi) }\end{array}$} & \multirow[b]{2}{*}{ Concentration } & \multirow{2}{*}{$\begin{array}{c}\text { Interruption } \\
\text { Time } \\
\text { (hr) }\end{array}$} & \multicolumn{2}{|c|}{$\begin{array}{l}\text { Total Activity } \\
\text { Ingested }\end{array}$} & \multicolumn{2}{|c|}{$\begin{array}{c}\text { Effective Dose Equivalent } \\
\text { (mrem) }\end{array}$} \\
\hline & & & & $(\mathrm{mCi})$ & (\%) & Newborn & 1-Yr-Old \\
\hline \multirow[t]{18}{*}{ Cr-51 EDTA } & 0.05 & minimum & 3 & $7.71 \mathrm{E}-06$ & $1.54 \mathrm{E}-02$ & $8.85 \mathrm{E}-04$ & $3.71 E-04$ \\
\hline & & & 12 & $3.14 \mathrm{E}-06$ & $6.27 \mathrm{E}-03$ & $3.60 \mathrm{E}-04$ & $1.51 E-04$ \\
\hline & & & 24 & $9.44 \mathrm{E}-07$ & $1.89 \mathrm{E}-03$ & $1.08 \mathrm{E}-04$ & $4.54 \mathrm{E}-05$ \\
\hline & & & 48 & $8.55 E-08$ & $1.71 \mathrm{E}-04$ & $9.81 \mathrm{E}-06$ & $4.11 \mathrm{E}-06$ \\
\hline & & & 96 & $7.02 \mathrm{E}-10$ & $1.40 \mathrm{E}-06$ & $8.06 \mathrm{E}-08$ & $3.38 \mathrm{E}-08$ \\
\hline & & & 120 & $6.37 \mathrm{E}-11$ & $1.27 \mathrm{E}-07$ & $7.30 \mathrm{E}-09$ & $3.06 \mathrm{E}-09$ \\
\hline & & & 168 & $5.23 \mathrm{E}-13$ & $1.05 \mathrm{E}-09$ & $6.00 \mathrm{E}-11$ & $2.51 \mathrm{E}-11$ \\
\hline & & & 336 & $1.56 \mathrm{E}-20$ & $3.12 \mathrm{E}-17$ & $1.79 \mathrm{E}-18$ & $7.50 \mathrm{E}-19$ \\
\hline & & & 672 & $0.00 \mathrm{E}+00$ & $0.00 \mathrm{E} \div 00$ & $0.00 \mathrm{E}+00$ & $0.00 \mathrm{E}+00$ \\
\hline & & maximum & 3 & $3.37 \mathrm{E}-05$ & $6.75 \mathrm{E}-02$ & $3.87 \mathrm{E}-03$ & $1.62 \mathrm{E}-03$ \\
\hline & & & 12 & $1.37 \mathrm{E}-05$ & $2.74 \mathrm{E}-02$ & $1.57 \mathrm{E}-03$ & $6.60 \mathrm{E}-04$ \\
\hline & & & 24 & $4.13 E-06$ & $8.26 \mathrm{E}-03$ & $4.74 \mathrm{E}-04$ & $1.99 \mathrm{E}-04$ \\
\hline & & & 48 & $3.74 \mathrm{E}-07$ & $7.48 \mathrm{E}-04$ & $4.29 \mathrm{E}-05$ & $1.80 \mathrm{E}-05$ \\
\hline & & & 96 & $3.07 \mathrm{E}-09$ & $6.15 \mathrm{E}-06$ & $3.53 \mathrm{E}-07$ & $1.48 \mathrm{E}-07$ \\
\hline & & & 120 & $2.79 \mathrm{E}-10$ & $5.57 \mathrm{E}-07$ & $3.19 \mathrm{E}-08$ & $1.34 \mathrm{E}-08$ \\
\hline & & & 168 & $2.29 \mathrm{E}-12$ & $4.58 \mathrm{E}-09$ & $2.62 \mathrm{E}-10$ & $1.10 \mathrm{E}-10$ \\
\hline & & & 336 & $6.82 \mathrm{E}-20$ & $1.36 \mathrm{E}-16$ & $7.82 \mathrm{E}-18$ & $3.28 \mathrm{E}-18$ \\
\hline & & & 672 & $0.00 \mathrm{E}+00$ & $0.00 \mathrm{E}+00$ & $0.00 \mathrm{E}+00$ & $0.00 \mathrm{E}+00$ \\
\hline \multirow[t]{18}{*}{ Ga-67 Citrate } & 5 & minimum & 3 & $4.09 \mathrm{E}-02$ & $8.17 \mathrm{E}-01$ & $2.72 \mathrm{E}+02$ & $1.04 \mathrm{E}+02$ \\
\hline & & & 12 & $2.76 \mathrm{E}-02$ & $5.52 \mathrm{E}-01$ & $1.84 \mathrm{E}+02$ & $7.05 \mathrm{E}+01$ \\
\hline & & & 24 & $1.64 \mathrm{E}-02$ & $3.28 \mathrm{E}-01$ & $1.09 \mathrm{E}+02$ & $4.18 \mathrm{E}+01$ \\
\hline & & & 48 & $5.77 \mathrm{E}-03$ & $1.15 E-01$ & $3.84 \mathrm{E}+01$ & $1.47 \mathrm{E}+01$ \\
\hline & & & 96 & $7.14 \mathrm{E}-04$ & $1.43 \mathrm{E}-02$ & $4.76 \mathrm{E}+00$ & $1.82 \mathrm{E}+00$ \\
\hline & & & 120 & $2.51 \mathrm{E}-04$ & $5.03 E-03$ & $1.67 \mathrm{E}+00$ & $6.42 \mathrm{E}-01$ \\
\hline & & & 168 & $3.11 \mathrm{E}-05$ & $6.23 \mathrm{E}-04$ & $2.07 \mathrm{E}-01$ & $7.95 \mathrm{E}-02$ \\
\hline & & & 336 & $2.08 \mathrm{E}-08$ & $4.17 \mathrm{E}-07$ & $1.39 \mathrm{E}-04$ & $5.32 \mathrm{E}-05$ \\
\hline & & & 672 & $9.27 \mathrm{E}-15$ & $1.85 \mathrm{E}-13$ & $6.17 \mathrm{E}-11$ & $2.37 \mathrm{E}-11$ \\
\hline & & maximum & 3 & $1.99 \mathrm{E}+00$ & $3.98 \mathrm{E}+01$ & $1.33 E+04$ & $5.08 \mathrm{E}+03$ \\
\hline & & & 12 & $1.81 \mathrm{E}+00$ & $3.62 \mathrm{E}+01$ & $1.20 \mathrm{E}+04$ & $4.62 \mathrm{E}+03$ \\
\hline & & & 24 & $1.59 \mathrm{E}+00$ & $3.18 \mathrm{E}+01$ & $1.06 \mathrm{E}+04$ & $4.06 \mathrm{E}+03$ \\
\hline & & & 48 & $1.23 E+00$ & $2.47 \mathrm{E}+01$ & $8.21 \mathrm{E}+03$ & $3.15 E+03$ \\
\hline & ' & & 96 & $7.40 \mathrm{E}-01$ & $1.48 \mathrm{E}+01$ & $4.93 E+03$ & $1.89 \mathrm{E}+03$ \\
\hline & & & 120 & $5.73 \mathrm{E}-01$ & $1.15 \mathrm{E}+01$ & $3.82 \mathrm{E}+03$ & $1.46 \mathrm{E}+03$ \\
\hline & & & 168 & $3.44 \mathrm{E}-01$ & $6.88 \mathrm{E}+00$ & $2.29 \mathrm{E}+03$ & $8.78 \mathrm{E}+02$ \\
\hline & & & 336 & $5.76 \mathrm{E}-02$ & $1.15 \mathrm{E}+00$ & $3.83 E+02$ & $1.47 E+02$ \\
\hline & & & 672 & $1.61 \mathrm{E}-03$ & $3.23 \mathrm{E}-02$ & $1.07 \mathrm{E}+01$ & $4.12 \mathrm{E}+00$ \\
\hline
\end{tabular}


Table B.4 Total Activity Ingested and Internal Radiation Doses Received from the Intake of Radiopharmaceuticals in Breast Milk Under Different Interruption Schedules (Continued)

\begin{tabular}{|c|c|c|c|c|c|c|c|}
\hline \multirow{2}{*}{$\begin{array}{l}\text { Radio- } \\
\text { pharmaceutical }\end{array}$} & \multirow{2}{*}{$\begin{array}{c}\text { Administered } \\
\text { Activity } \\
\text { (mCi) }\end{array}$} & \multirow[b]{2}{*}{ Concentration } & \multirow{2}{*}{$\begin{array}{c}\text { Interruption } \\
\text { Time } \\
\text { (hr) }\end{array}$} & \multicolumn{2}{|c|}{$\begin{array}{l}\text { Total Activity } \\
\text { Ingested }\end{array}$} & \multicolumn{2}{|c|}{$\begin{array}{c}\text { Effective Dose Equivalent } \\
\text { (mrem) }\end{array}$} \\
\hline & & & & $(\mathrm{mCi})$ & $(\%)$ & Newborn & 1-Yr-Old \\
\hline \multirow[t]{18}{*}{ I-123 mIBG* } & 10 & minimum & 3 & $5.41 \mathrm{E}-02$ & $5.41 \mathrm{E}-01$ & $3.20 \mathrm{E}+02$ & $2.20 E+02$ \\
\hline & & & 12 & $3.13 \mathrm{E}-02$ & $3.13 E-01$ & $1.86 \mathrm{E}+02$ & $1.28 \mathrm{E}+02$ \\
\hline & & & 24 & $1.51 \mathrm{E}-02$ & $1.51 \mathrm{E}-01$ & $8.97 \mathrm{E}+01$ & $6.16 \mathrm{E}+01$ \\
\hline & & & 48 & $3.53 \mathrm{E}-03$ & $3.53 \mathrm{E}-02$ & $2.10 \mathrm{E}+01$ & $1.44 \mathrm{E}+01$ \\
\hline & & & 96 & $1.92 \mathrm{E}-04$ & $1.92 \mathrm{E}-03$ & $1.19 \mathrm{E}+00$ & $8.02 \mathrm{E}-01$ \\
\hline & & & 120 & $4.48 \mathrm{E}-05$ & $4.48 \mathrm{E}-04$ & $3.04 \mathrm{E}-01$ & $1.99 \mathrm{E}-01$ \\
\hline & & & 168 & $2.44 \mathrm{E}-06$ & $2.44 \mathrm{E}-05$ & $4.01 \mathrm{E}-02$ & $2.09 \mathrm{E}-02$ \\
\hline & & & 336 & $9.15 \mathrm{E}-11$ & $9.15 \mathrm{E}-10$ & $6.03 \mathrm{E}-03$ & $2.57 \mathrm{E}-03$ \\
\hline & & & 672 & $0.00 \mathrm{E}+00$ & $0.00 \mathrm{E}+00$ & $3.31 \mathrm{E}-04$ & $1.41 \mathrm{E}-04$ \\
\hline & & maxmimum & 3 & $5.41 \mathrm{E}-02$ & $5.41 \mathrm{E}-01$ & $3.20 \mathrm{E}+02$ & $2.20 \mathrm{E}+02$ \\
\hline & & & 12 & $3.13 \mathrm{E}-02$ & $3.13 \mathrm{E}-01$ & $1.86 \mathrm{E}+02$ & $1.28 \mathrm{E}+02$ \\
\hline & & & 24 & $1.51 E-02$ & $1.51 \mathrm{E}-01$ & $8.97 \mathrm{E}+01$ & $6.16 \mathrm{E}+01$ \\
\hline & & & 48 & $3.53 \mathrm{E}-03$ & $3.53 \mathrm{E}-02$ & $2.10 \mathrm{E}+01$ & $1.44 \mathrm{E}+01$ \\
\hline & & & 96 & $1.92 \mathrm{E}-04$ & $1.92 \mathrm{E}-03$ & $1.19 E+00$ & $8.02 E-01$ \\
\hline & & & 120 & $4.48 \mathrm{E}-05$ & $4.48 \mathrm{E}-04$ & $3.04 \mathrm{E}-01$ & $1.99 \mathrm{E}-01$ \\
\hline & & & 168 & $2.44 \mathrm{E}-06$ & $2.44 \mathrm{E}-05$ & $4.01 \mathrm{E}-02$ & $2.09 \mathrm{E}-02$ \\
\hline & & & 336 & $9.15 \mathrm{E}-11$ & $9.15 \mathrm{E}-10$ & $6.03 E-03$ & $2.57 \mathrm{E}-03$ \\
\hline & & & 672 & $0.00 \mathrm{E}+00$ & $0.00 \mathrm{E}+00$ & $3.31 \mathrm{E}-04$ & $1.41 \mathrm{E}-04$ \\
\hline \multirow[t]{18}{*}{ I-123 OIH* } & 2 & minimum & 3 & $1.63 \mathrm{E}-02$ & $8.13 E-01$ & $3.85 \mathrm{E}+00$ & $1.62 \mathrm{E}+00$ \\
\hline & & & 12 & $2.76 \mathrm{E}-03$ & $1.38 \mathrm{E}-01$ & $6.54 \mathrm{E}-01$ & $2.76 \mathrm{E}-01$ \\
\hline & & & 24 & $2.60 \mathrm{E}-04$ & $1.30 \mathrm{E}-02$ & $6.17 \mathrm{E}-02$ & $2.60 \mathrm{E}-02$ \\
\hline & & & 48 & $2.31 \mathrm{E}-06$ & $1.15 \mathrm{E}-04$ & $5.49 \mathrm{E}-04$ & $2.32 \mathrm{E}-04$ \\
\hline & & & 96 & $1.82 \mathrm{E}-10$ & $9.08 \mathrm{E}-09$ & $4.46 \mathrm{E}-08$ & $1.89 \mathrm{E}-08$ \\
\hline & & & 120 & $1.61 \mathrm{E}-12$ & $8.06 \mathrm{E}-11$ & $4.32 \mathrm{E}-10$ & $1.82 \mathrm{E}-10$ \\
\hline & & & 168 & $8.79 \mathrm{E}-17$ & $4.40 \mathrm{E}-15$ & $6.84 \mathrm{E}-14$ & $2.88 \mathrm{E}-14$ \\
\hline & & & 336 & $0.00 \mathrm{E}+00$ & $0.00 \mathrm{E}+00$ & $0.00 \mathrm{E}+00$ & $0.00 \mathrm{E}+00$ \\
\hline & & & 672 & $0.00 \mathrm{E}+00$ & $0.00 \mathrm{E}+00$ & $0.00 \mathrm{E}+00$ & $0.00 \mathrm{E}+00$ \\
\hline & & maxmimum & 3 & $1.24 \mathrm{E}-01$ & $6.18 \mathrm{E}+00$ & $2.93 \mathrm{E}+01$ & $1.24 \mathrm{E}+01$ \\
\hline & & & 12 & $4.18 \mathrm{E}-02$ & $2.09 \mathrm{E}+00$ & $9.92 \mathrm{E}+00$ & $4.18 \mathrm{E}+00$ \\
\hline & & & 24 & $9.86 \mathrm{E}-03$ & $4.93 \mathrm{E}-01$ & $2.33 \mathrm{E}+00$ & $9.865 \mathrm{E}-01$ \\
\hline & & & 48 & $5.48 \mathrm{E}-04$ & $2.74 \mathrm{E}-02$ & $1.31 \mathrm{E}-01$ & $5.49 \mathrm{E}-02$ \\
\hline & & & 96 & $1.69 \mathrm{E}-06$ & $8.45 \mathrm{E}-05$ & $4.19 \mathrm{E}-04$ & $1.77 \mathrm{E}-04$ \\
\hline & & & 120 & $9.38 \mathrm{E}-08$ & $4.69 \mathrm{E}-06$ & $2.59 \mathrm{E}-05$ & $1.09 \mathrm{E}-05$ \\
\hline & & & 168 & $2.89 \mathrm{E}-10$ & $1.45 \mathrm{E}-08$ & $2.09 \mathrm{E}-07$ & $8.78 \mathrm{E}-08$ \\
\hline & & & 336 & $0.00 \mathrm{E}+00$ & $0.00 \mathrm{E}+00$ & $1.43 \mathrm{E}-12$ & $6.00 \mathrm{E}-13$ \\
\hline & & & 672 & $0.00 \mathrm{E}+00$ & $0.00 \mathrm{E}+00$ & $0.00 \mathrm{E}+00$ & $0.00 \mathrm{E}+00$ \\
\hline
\end{tabular}

* Includes the dose from radioactive contaminants. See Section B.1 CALCULATIONAL METHOD for details. 
Table B.4 Total Activity Ingested and Internal Radiation Doses Received from the Intake of Radiopharmaceuticals in Breast Milk Under Different Interruption Schedules (Continued)

\begin{tabular}{|c|c|c|c|c|c|c|c|}
\hline \multirow{2}{*}{$\begin{array}{l}\text { Radio- } \\
\text { pharmaceutical }\end{array}$} & \multirow{2}{*}{$\begin{array}{l}\text { Administered } \\
\text { Activity } \\
\text { (mCi) }\end{array}$} & \multirow[b]{2}{*}{ Concentration } & \multirow{2}{*}{$\begin{array}{c}\text { Interruption } \\
\text { Time } \\
\text { (hr) }\end{array}$} & \multicolumn{2}{|c|}{$\begin{array}{l}\text { Total Activity } \\
\text { Ingested }\end{array}$} & \multicolumn{2}{|c|}{$\begin{array}{c}\text { Effective Dose Equivalent } \\
\text { (mrem) }\end{array}$} \\
\hline & & & & $(\mathrm{mCi})$ & $(\%)$ & Newborn & 1-Yr-OId \\
\hline \multirow[t]{18}{*}{ I-123 NaI* } & 0.4 & minimum & 3 & $1.03 E-02$ & $2.58 \mathrm{E}+00$ & $6.12 \mathrm{E}+01$ & $4.21 \mathrm{E}+01$ \\
\hline & & & 12 & $3.53 \mathrm{E}-03$ & $8.83 \mathrm{E}-01$ & $2.09 \mathrm{E}+01$ & $1.44 \mathrm{E}+01$ \\
\hline & & & 24 & $8.45 \mathrm{E}-04$ & $2.11 \mathrm{E}-01$ & $5.01 E+00$ & $3.45 \mathrm{E}+00$ \\
\hline & & & 48 & $4.84 \mathrm{E}-05$ & $1.21 \mathrm{E}-02$ & $2.89 \mathrm{E}-01$ & $1.98 \mathrm{E}-01$ \\
\hline & & & 96 & $1.59 \mathrm{E}-07$ & $3.98 \mathrm{E}-05$ & $9.61 \mathrm{E}-04$ & $6.62 \mathrm{E}-04$ \\
\hline & & & 120 & $9.12 \mathrm{E}-09$ & $2.28 \mathrm{E}-06$ & $5.61 \mathrm{E}-05$ & $3.86 \mathrm{E}-05$ \\
\hline & & & 168 & $3.00 \mathrm{E}-11$ & $7.49 \mathrm{E}-09$ & $2.02 E-07$ & $1.40 \mathrm{E}-07$ \\
\hline & & & 336 & $0.00 \mathrm{E}+00$ & $0.00 \mathrm{E}+00$ & $5.08 \mathrm{E}-15$ & $3.68 \mathrm{E}-15$ \\
\hline & & & 672 & $0.00 \mathrm{E}+00$ & $0.00 \mathrm{E}+00$ & $0.00 \mathrm{E}+00$ & $0.00 \mathrm{E}+00$ \\
\hline & & maxmimum & 3 & $1.08 \mathrm{E}-02$ & $2.70 \mathrm{E}+00$ & $7.04 \mathrm{E}+01$ & $4.87 \mathrm{E}+01$ \\
\hline & & & 12 & $3.70 \mathrm{E}-03$ & $9.25 \mathrm{E}-01$ & $2.83 \mathrm{E}+01$ & $1.98 \mathrm{E}+01$ \\
\hline & & & 24 & $8.86 \mathrm{E}-04$ & $2.22 \mathrm{E}-01$ & 1.17E+01 & $8.27 \mathrm{E}+00$ \\
\hline & & & 48 & $5.08 \mathrm{E}-05$ & $1.27 \mathrm{E}-02$ & $6.74 \mathrm{E}+00$ & $4.87 \mathrm{E}+00$ \\
\hline & . & & 96 & $1.67 \mathrm{E}-07$ & $4.17 \mathrm{E}-05$ & $6.44 \mathrm{E}+00$ & $4.66 \mathrm{E}+00$ \\
\hline & & & 120 & $9.56 \mathrm{E}-09$ & $2.39 \mathrm{E}-06$ & $6.44 \mathrm{E}+00$ & $4.66 \mathrm{E}+00$ \\
\hline & & . & 168 & $3.14 \mathrm{E}-11$ & $7.85 \mathrm{E}-09$ & $6.44 \mathrm{E}+00$ & $4.66 \mathrm{E}+00$ \\
\hline & & & 336 & $0.00 \mathrm{E}+00$ & $0.00 \mathrm{E}+00$ & $6.44 \mathrm{E}+00$ & $4.66 \mathrm{E}+00$ \\
\hline & & & 672 & $0.00 \mathrm{E}+00$ & $0.00 \mathrm{E}+00$ & $7.82 \mathrm{E}-01$ & $5.66 \mathrm{E}-01$ \\
\hline \multirow[t]{18}{*}{$\mathrm{I}-125 \mathrm{OIH}$} & 0.01 & minimum & 3 & $2.52 E-04$ & $2.52 \mathrm{E}+00$ & $2: 24 \mathrm{E}-01$ & $9.04 \mathrm{E}-02$ \\
\hline & & & 12 & $6.84 \mathrm{E}-05$ & $6.84 \mathrm{E}-01$ & $6.07 \mathrm{E}-02$ & $2.45 \mathrm{E}-02$ \\
\hline & & & 24 & $1.20 \mathrm{E}-05$ & $1.20 \mathrm{E}-01$ & $1.07 \mathrm{E}-02$ & $4.31 \mathrm{E}-03$ \\
\hline & & & 48 & $3.72 E-07$ & $3.72 E-03$ & $3.30 \mathrm{E}-04$ & $1.33 E-04$ \\
\hline & & & 96 & $3.55 \mathrm{E}-10$ & $3.55 \mathrm{E}-06$ & $3.15 \mathrm{E}-07$ & $1.27 \mathrm{E}-07$ \\
\hline & & & 120 & $1.10 \mathrm{E}-11$ & $1.10 \mathrm{E}-07$ & $9.75 \mathrm{E}-09$ & $3.94 \mathrm{E}-09$ \\
\hline & & & 168 & $1.05 \mathrm{E}-14$ & $1.05 \mathrm{E}-10$ & $9.32 \mathrm{E}-12$ & $3.77 \mathrm{E}-12$ \\
\hline & & & 336 & $0.00 \mathrm{E}+00$ & $0.00 \mathrm{E}+00$ & $0.00 \mathrm{E}+00$ & $0.00 \mathrm{E}+00$ \\
\hline & & & 672 & $0.00 \mathrm{E}+00$ & $0.00 E+00$ & $0.00 \mathrm{E}+00$ & $0.00 \mathrm{E}+00$ \\
\hline & & maxmimum & 3 & $2.52 \mathrm{E}-04$ & $2.52 \mathrm{E}+00$ & $2.24 \mathrm{E}-01$ & $9.04 \mathrm{E}-02$ \\
\hline & & & 12 & $6.84 \mathrm{E}-05$ & $6.84 \mathrm{E}-01$ & $6.07 \mathrm{E}-02$ & $2.54 \mathrm{E}-02$ \\
\hline & & & 24 & $1.20 \mathrm{E}-05$ & $1.20 \mathrm{E}-01$ & $1.07 \mathrm{E}-02$ & $4.31 \mathrm{E}-03$ \\
\hline & & & 48 & $3.72 \mathrm{E}-07$ & $3.72 \mathrm{E}-03$ & $3.30 \mathrm{E}-04$ & $1.33 \mathrm{E}-04$ \\
\hline & & & 96 & $3.55 \mathrm{E}-10$ & $3.55 \mathrm{E}-06$ & $3.15 \mathrm{E}-07$ & $1.27 \mathrm{E}-07$ \\
\hline & & & 120 & $1.10 \mathrm{E}-11$ & $1.10 \mathrm{E}-07$ & $9.75 E-09$ & $3.94 \mathrm{E}-09$ \\
\hline & & & 168 & $1.05 \mathrm{E}-14$ & $1.05 E-10$ & $9.32 \mathrm{E}-12$ & $3.77 \mathrm{E}-12$ \\
\hline & & & 336 & $0.00 \mathrm{E}+00$ & $0.00 \mathrm{E}+00$ & $0.00 \mathrm{E}+00$ & $0.00 \mathrm{E}+00$ \\
\hline & & & 672 & $0.00 \mathrm{E}+00$ & $0.00 \mathrm{E}+00$ & $0.00 \mathrm{E}+00$ & $0.00 \mathrm{E}+00$ \\
\hline
\end{tabular}

* Includes the dose from radioactive contaminants. See Section B.1 CALCULATIONAL METHOD for details. 
Table B.4 Total Activity Ingested and Internal Radiation Doses Received from the Intake of Radiopharmaceuticals in Breast Milk Under Different Interruption Schedules (Continued)

\begin{tabular}{|c|c|c|c|c|c|c|c|}
\hline \multirow{2}{*}{$\begin{array}{l}\text { Radio- } \\
\text { pharmaceutical }\end{array}$} & \multirow{2}{*}{$\begin{array}{l}\text { Administered } \\
\text { Activity } \\
\text { (mCi) }\end{array}$} & \multirow[b]{2}{*}{ Concentration } & \multirow{2}{*}{$\begin{array}{l}\text { Interruption } \\
\text { Time } \\
\text { (hr) }\end{array}$} & \multicolumn{2}{|c|}{$\begin{array}{l}\text { Total Activity } \\
\text { Ingested }\end{array}$} & \multicolumn{2}{|c|}{$\begin{array}{c}\text { Effective Dose Equivalent } \\
\text { (mrem) }\end{array}$} \\
\hline & & & & $(\mathrm{mCl})$ & (\%) & Newborn & 1-Yr-Old \\
\hline \multirow[t]{18}{*}{ I-131 OIH } & 0.3 & minimum & 3 & $2.62 \mathrm{E}-03$ & $8.73 \mathrm{E}-01$ & $2.91 E+00$ & $1.16 \mathrm{E}+00$ \\
\hline & & & 12 & $1.49 \mathrm{E}-04$ & $4.96 \mathrm{E}-02$ & $1.65 E-01$ & $6.61 \mathrm{E}-02$ \\
\hline & & & 24 & $3.26 \mathrm{E}-06$ & $1.09 E-03$ & $3.61 E-03$ & $1.45 \mathrm{E}-03$ \\
\hline & & & 48 & $1.56 \mathrm{E}-09$ & $5.19 \mathrm{E}-07$ & $1.73 \mathrm{E}-06$ & $6.91 \mathrm{E}-07$ \\
\hline & & & 96 & $3.48 \mathrm{E}-16$ & $1.16 \mathrm{E}-13$ & $3.86 \mathrm{E}-13$ & $1.54 \mathrm{E}-13$ \\
\hline & & & 120 & $0.00 \mathrm{E}+00$ & $0.00 \mathrm{E}+00$ & $0.00 \mathrm{E}+00$ & $0.00 \mathrm{E}+00$ \\
\hline & & & 168 & $0.00 \mathrm{E}+00$ & $0.00 \mathrm{E}+00$ & $0.00 \mathrm{E}+00$ & $0.00 \mathrm{E}+00$ \\
\hline & & & 336 & $0.00 \mathrm{E}+00$ & $0.00 \mathrm{E}+00$ & $0.00 \mathrm{E}+00$ & $0.00 \mathrm{E}+00$ \\
\hline & & & 672 & $0.00 \mathrm{E}+00$ & $0.00 \mathrm{E}+00$ & $0.00 \mathrm{E}+00$ & $0.00 \mathrm{E}+00$ \\
\hline & & maxmimum & 3 & $1.50 \mathrm{E}-02$ & $4.99 \mathrm{E}+00$ & $1.66 \mathrm{E}+01$ & $6.65 \mathrm{E}+00$ \\
\hline & & & 12 & $5.13 \mathrm{E}-03$ & $1.71 \mathrm{E}+00$ & $5.69 \mathrm{E}+00$ & $2.29 \mathrm{E}+00$ \\
\hline & & & 24 & $1.23 \mathrm{E}-03$ & $4.09 \mathrm{E}-01$ & $1.36 \mathrm{E}+00$ & $5.45 \mathrm{E}-01$ \\
\hline & & & 48 & $7.05 \mathrm{E}-05$ & $2.35 \mathrm{E}-02$ & $7.82 \mathrm{E}-02$ & $3.13 E-02$ \\
\hline & & & 96 & $2.32 \mathrm{E}-07$ & $7.73 E-05$ & $2.58 \mathrm{E}-04$ & $1.03 \mathrm{E}-04$ \\
\hline & & & 120 & $1.33 E-08$ & $4.44 \mathrm{E}-06$ & $1.48 \mathrm{E}-05$ & $5.91 \mathrm{E}-06$ \\
\hline & & & 168 & $4.38 \mathrm{E}-11$ & $1.46 \mathrm{E}-08$ & $4.86 \mathrm{E}-08$ & $1.95 \mathrm{E}-08$ \\
\hline & & & 336 & $0.00 \mathrm{E}+00$ & $0.00 \mathrm{E}+00$ & $0.00 \mathrm{E}+00$ & $0.00 \mathrm{E}+00$ \\
\hline & & & 672 & $0.00 \mathrm{E}+00$ & $0.00 \mathrm{E}+00$ & $0.00 \mathrm{E}+00$ & $0.00 \mathrm{E}+00$ \\
\hline \multirow{18}{*}{$\begin{array}{l}\text { I-131 Sodium Iodide } \\
\text { (NaI) }\end{array}$} & 150 & minimum & 3 & $1.06 \mathrm{E}+00$ & $7.07 \mathrm{E}-01$ & $2.08 \mathrm{E}+07^{*}$ & $1.53 \mathrm{E}+07^{*}$ \\
\hline & & & 12 & $4.52 E-01$ & $3.01 \mathrm{E}-01$ & $8.86 \mathrm{E}+06^{*}$ & $6.52 \mathrm{E}+06^{*}$ \\
\hline & & & 24 & $1.45 \mathrm{E}-01$ & $9.66 \mathrm{E}-02$ & $2.84 \mathrm{E}+06^{*}$ & $2.09 \mathrm{E}+06^{*}$ \\
\hline & & & 48 & $1.49 \mathrm{E}-02$ & $9.94 \mathrm{E}-03$ & $2.92 \mathrm{E}+05^{*}$ & $2.15 \mathrm{E}+05^{*}$ \\
\hline & & & 96 & $1.58 \mathrm{E}-04$ & $1.05 \mathrm{E}-04$ & $3.10 E+03 *$ & $2.28 \mathrm{E}+03 *$ \\
\hline & & & 120 & $1.62 \mathrm{E}-05$ & $1.08 \mathrm{E}-05$ & $3.18 \mathrm{E}+02^{*}$ & $2.33 E+02 *$ \\
\hline & & & 168 & $1.71 \mathrm{E}-07$ & $1.14 \mathrm{E}-07$ & $3.35 \mathrm{E}+00 *$ & $2.47 \mathrm{E}+00 *$ \\
\hline & & & 336 & $1.92 E-14$ & $1.28 \mathrm{E}-14$ & $3.76 \mathrm{E}-07 *$ & $2.77 \mathrm{E}-07 *$ \\
\hline & & & 672 & $0.00 \mathrm{E}+00$ & $0.00 \mathrm{E}+00$ & $0.00 \mathrm{E}+00 *$ & $0.00 \mathrm{E}+00 *$ \\
\hline & & $\operatorname{maxmimum} * *$ & 3 & $7.50 \mathrm{E}+01$ & $5.00 \mathrm{E}+01$ & $1.47 \mathrm{E}+09^{*}$ & $1.08 \mathrm{E}+09 *$ \\
\hline & & & 12 & $7.50 \mathrm{E}+01$ & $5.00 \mathrm{E}+01$ & $1.47 \mathrm{E}+09 *$ & $1.08 \mathrm{E}+09 *$ \\
\hline & & & 24 & $7.50 \mathrm{E}+01$ & $5.00 \mathrm{E}+01$ & $1.47 \mathrm{E}+09 *$ & $1.08 \mathrm{E}+09 *$ \\
\hline & & & 48 & $7.50 \mathrm{E}+01$ & $5.00 \mathrm{E}+01$ & $1.47 \mathrm{E}+09 *$ & $1.08 \mathrm{E}+09 *$ \\
\hline & & & 96 & $7.50 \mathrm{E}+01$ & $5.00 \mathrm{E}+01$ & $1.47 \mathrm{E}+09 *$ & $1.08 \mathrm{E}+09 *$ \\
\hline & & & 120 & $7.50 \mathrm{E}+01$ & $5.00 \mathrm{E}+01$ & $1.47 \mathrm{E}+09 *$ & $1.08 \mathrm{E}+09 *$ \\
\hline & & & 168 & $7.50 \mathrm{E}+01$ & $5.00 \mathrm{E}+01$ & $1.47 \mathrm{E}+09 *$ & $1.08 \mathrm{E}+09 *$ \\
\hline & & & 336 & $1.88 \mathrm{E}+01$ & $1.25 \mathrm{E}+01$ & $3.69 \mathrm{E}+08 *$ & $2.71 \mathrm{E}+08 *$ \\
\hline & & & 672 & $7.68 \mathrm{E}-01$ & $5.12 \mathrm{E}-01$ & $1.51 \mathrm{E}+07 *$ & $1.11 \mathrm{E}+07^{*}$ \\
\hline
\end{tabular}

* Dose to the infant thyroid, mrad.

** The values under Total Activity Ingested and Effective Dose Equivalent for interruption times 3 to 168 hours show no change with time because the total fraction of administered activity excreted in the breast milk exceeded the upper limit (or cap) of 0.50 (see Section B.1 CALCULATIONAL METHOD). 
Table B.4 Total Activity Ingested and Internal Radiation Doses Received from the Intake of Radiopharmaceuticals in Breast Milk Under Different Interruption Schedules (Continued)

\begin{tabular}{|c|c|c|c|c|c|c|c|}
\hline \multirow{2}{*}{$\begin{array}{l}\text { Radio- } \\
\text { pharmaceutical }\end{array}$} & \multirow{2}{*}{$\begin{array}{l}\text { Administered } \\
\text { Activity } \\
\text { (mCi) }\end{array}$} & \multirow[b]{2}{*}{ Concentration } & \multirow{2}{*}{$\begin{array}{c}\text { Interruption } \\
\text { - Time : } \\
\text { (hr) }\end{array}$} & \multicolumn{2}{|c|}{$\begin{array}{l}\text { Total Activity } \\
\text { Ingested }\end{array}$} & \multicolumn{2}{|c|}{$\begin{array}{c}\text { Effective Dose Equivalent } \\
\text { (mrem) }\end{array}$} \\
\hline & & & & $(\mathbf{m C i})$ & (\%) & Newborn & 1-Yr-Old \\
\hline In-111 & 0.5 & minimum & 3 & $6.21 \mathrm{E}-04$ & $1.24 \mathrm{E}-01$ & $3.53 E+01$ & $1.32 E+01$ \\
\hline \multirow[t]{17}{*}{ White Blood Cells* } & & & 12 & $5.77 \mathrm{E}-04$ & $1.15 \mathrm{E}-01$ & $3.29 \mathrm{E}+01$ & $1.23 \mathrm{E}+01$ \\
\hline & & & 24 & $5.23 \mathrm{E}-04$ & $1.05 \mathrm{E}-01$ & $2.98 \mathrm{E}+01$ & $1.11 \mathrm{E}+01$ \\
\hline & & & 48 & $4.30 \mathrm{E}-04$ & $8.60 \mathrm{E}-02$ & $2.45 \mathrm{E}+01$ & $9.15 \mathrm{E}+00$ \\
\hline & & & 96 & $2.91 \mathrm{E}-04$ & $5.82 \mathrm{E}-02$ & $1.66 \mathrm{E}+01$ & $6.19 \mathrm{E}+00$ \\
\hline & & & 120 & $2.39 \mathrm{E}-04$ & $4.78 \mathrm{E}-02$ & $1.36 \mathrm{E}+01$ & $5.09 \mathrm{E}+00$ \\
\hline & & & 168 & $1.62 \mathrm{E}-04$ & $3.23 E-02$ & $9.21 \mathrm{E}+00$ & $3.44 \mathrm{E}+00$ \\
\hline & & & 336 & $4.11 \mathrm{E}-05$ & $=8.22 \mathrm{E}-03$ & $2.34 \mathrm{E}+00$ & $8.74 \mathrm{E}-01$ \\
\hline & & & 672 & $2.66 \mathrm{E}-06$ & $5.31 \mathrm{E}-04$ & $1.51 \mathrm{E}-01$ & $5.65 \mathrm{E}-02$ \\
\hline & & maxmimum & 3 & $3.10 \mathrm{E}-03$ & $6.19 \mathrm{E}-01$ & $1.76 \mathrm{E}+02$ & $6.59 \mathrm{E}+01$ \\
\hline & & & 12 & $2.96 \mathrm{E}-03$ & $5.92 \mathrm{E}-01$ & $1.69 \mathrm{E}+02$ & $6.29 \mathrm{E}+01$ \\
\hline & & & 24 & $2.79 \mathrm{E}-03$ & $5.58 \mathrm{E}-01$ & $1.59 \mathrm{E}+02$ & $5.93 \mathrm{E}+01$ \\
\hline & & & 48 & $2.48 \mathrm{E}-03$ & $4.95 \mathrm{E}-01$ & $1.41 \mathrm{E}+02$ & $5.27 \mathrm{E}+01$ \\
\hline & & & 96 & $1.95 \mathrm{E}-03$ & $3.91 \mathrm{E}-01$ & $1.11 \mathrm{E}+02$ & $4.16 \mathrm{E}+01$ \\
\hline & & & 120 & $1.73 \mathrm{E}-03$ & $3.47 \mathrm{E}-01$ & $9.88 \mathrm{E}+01$ & $3.69 \mathrm{E}+01$ \\
\hline & & & 168 & $1.37 \mathrm{E}-03$ & $2.74 \mathrm{E}-01$ & $7.79 \mathrm{E}+01$ & $2.91 \mathrm{E}+01$ \\
\hline & & & 336 & $5.95 \mathrm{E}-04$ & $1.19 \mathrm{E}-01$ & $3.39 \mathrm{E}+01$ & $1.27 \mathrm{E}+01$ \\
\hline & & & 672 & $1.13 E-04$ & $2.26 \mathrm{E}-02$ & $6.43 E+00$ & $2.40 \mathrm{E}+00$ \\
\hline \multirow[t]{18}{*}{ Tc-99m DISIDA } & 8 & minimum & 3 & $5.64 \mathrm{E}-03$ & $9.99 \mathrm{E}-02$ & $6.80 \mathrm{E}+00$ & $3.25 \mathrm{E}+00$ \\
\hline & & & 12 & $1.07 \mathrm{E}-03$ & $1.90 \mathrm{E}-02$ & $1.29 \mathrm{E}+00$ & $6.18 \mathrm{E}-01$ \\
\hline & & & 24 & $1.17 \mathrm{E}-04$ & $2.07 \mathrm{E}-03$ & $1.41 \mathrm{E}-01$ & $6.74 \mathrm{E}-02$ \\
\hline & & & 48 & $1.39 \mathrm{E}-06$ & $2.47 \mathrm{E}-05$ & $1.68 \mathrm{E}-03$ & $8.03 E-04$ \\
\hline & & & 96 & $1.97 \mathrm{E}-10$ & $3.50 \mathrm{E}-09$ & $2.38 \mathrm{E}-07$ & $1.14 \mathrm{E}-07$ \\
\hline & & & 120 & $2.35 \mathrm{E}-12$ & $4.16 \mathrm{E}-11$ & $2.83 \mathrm{E}-09$ & $1.36 \mathrm{E}-09$ \\
\hline & & & 168 & $3.21 \mathrm{E}-16$ & $5.69 \mathrm{E}-15$ & $3.87 \mathrm{E}-13$ & $1.85 \mathrm{E}-13$ \\
\hline & & & 336 & $0.00 \mathrm{E}+00$ & $0.00 \mathrm{E}+00$ & $0.00 \mathrm{E}+00$ & $0.00 \mathrm{E}+00$ \\
\hline & & & 672 & $0.00 \mathrm{E}+00$ & $0.00 \mathrm{E}+00$ & $0.00 \mathrm{E}+00$ & $0.00 \mathrm{E}+00$ \\
\hline & & maxmimum & 3 & $2.25 \mathrm{E}-02$ & $2.82 \mathrm{E}-01$ & $1.92 \mathrm{E}+01$ & $9.17 \mathrm{E}+00$ \\
\hline & & & 12 & $1.13 \mathrm{E}-02$ & $1.42 \mathrm{E}-01$ & $9.66 \mathrm{E}+00$ & $4.62 \mathrm{E}+00$ \\
\hline & & & 24 & $4.55 \mathrm{E}-03$ & $5.69 \mathrm{E}-02$ & $3.87 \mathrm{E}+00$ & $1.85 \mathrm{E}+00$ \\
\hline & & & 48 & $7.32 \mathrm{E}-04$ & $9.15 \mathrm{E}-03$ & $6.23 \mathrm{E}-01$ & $2.98 \mathrm{E}-01$ \\
\hline & & & 96 & $1.89 \mathrm{E}-05$ & $2.36 \mathrm{E}-04$ & $1.61 \mathrm{E}-02$ & $7.70 \mathrm{E}-03$ \\
\hline & & & 120 & $3.04 \mathrm{E}-06$ & $3.80 \mathrm{E}-05$ & $2.59 \mathrm{E}-03$ & $1.24 \mathrm{E}-03$ \\
\hline & & & 168 & $7.86 \mathrm{E}-08$ & $9.83 E-07$ & $-6.69 \mathrm{E}-05$ & $3.20 \mathrm{E}-05$ \\
\hline & & & 336 & $2.18 \mathrm{E}-13$ & $2.73 E-12$ & $1.86 \mathrm{E}-10$ & $8.89 \mathrm{E}-11$ \\
\hline & & & 672 & $0.00 \mathrm{E}+00$ & $0.00 \mathrm{E}+00$ & $0.00 \mathrm{E}+00$ & $0.00 \mathrm{E}+00$ \\
\hline
\end{tabular}

* Includes the dose from radioactive contaminants. See Section B.1 CALCULATIONAL METHOD for details. 
Table B.4 Total Activity Ingested and Internal Radiation Doses Received from the Intake of Radiopharmaceuticals in Breast Milk Under Different Interruption Schedules (Continued)

\begin{tabular}{|c|c|c|c|c|c|c|c|}
\hline \multirow{2}{*}{$\begin{array}{l}\text { Radio- } \\
\text { pharmaceutical }\end{array}$} & \multirow{2}{*}{$\begin{array}{c}\text { Administered } \\
\text { Activity } \\
\text { (mCi) }\end{array}$} & \multirow[b]{2}{*}{ Concentration } & \multirow{2}{*}{$\begin{array}{c}\text { Interruption } \\
\text { Time } \\
\text { (hr) }\end{array}$} & \multicolumn{2}{|c|}{$\begin{array}{l}\text { Total Activity } \\
\text { Ingested }\end{array}$} & \multicolumn{2}{|c|}{$\begin{array}{c}\text { Effective Dose Equivalent } \\
\text { (mrem) }\end{array}$} \\
\hline & & & & $(\mathrm{mCi})$ & $(\%)$ & Newborn & 1-Yr-Old \\
\hline \multirow[t]{18}{*}{ Tc-99m DTPA } & 20 & minimum & 3 & $2.57 \mathrm{E}-03$ & $1.29 \mathrm{E}-02$ & $3.23 \mathrm{E}-01$ & $1.43 \mathrm{E}-01$ \\
\hline & & & 12 & $3.49 \mathrm{E}-04$ & $1.74 \mathrm{E}-03$ & $4.39 \mathrm{E}-02$ & $1.94 \mathrm{E}-02$ \\
\hline & & & 24 & $2.43 E-05$ & $1.22 \mathrm{E}-04$ & $3.06 \mathrm{E}-03$ & $1.35 \mathrm{E}-03$ \\
\hline & & & 48 & $1.18 \mathrm{E}-07$ & $5.92 \mathrm{E}-07$ & $1.49 E-05$ & $6.57 \mathrm{E}-06$ \\
\hline & & & 96 & $2.80 \mathrm{E}-12$ & $1.40 \mathrm{E}-11$ & $3.52 \mathrm{E}-10$ & $1.55 \mathrm{E}-10$ \\
\hline & & & 120 & $1.36 \mathrm{E}-14$ & $6.80 \mathrm{E}-14$ & $1.71 \mathrm{E}-12$ & $7.55 \mathrm{E}-13$ \\
\hline & & & 168 & $0.00 \mathrm{E}+00$ & $0.00 \mathrm{E}+00$ & $0.00 \mathrm{E}+00$ & $0.00 \mathrm{E}+00$ \\
\hline & & & 336 & $0.00 \mathrm{E}+00$ & $0.00 \mathrm{E}+00$ & $0.00 \mathrm{E}+00$ & $0.00 \mathrm{E}+00$ \\
\hline & & & 672 & $0.00 \mathrm{E}+00$ & $0.00 \mathrm{E}+00$ & $0.00 \mathrm{E}+00$ & $0.00 \mathrm{E}+00$ \\
\hline & & maxmimum & 3 & $4.78 \mathrm{E}-02$ & $2.39 \mathrm{E}-01$ & $6.02 \mathrm{E}+00$ & $2.65 \mathrm{E}+00$ \\
\hline & & & 12 & $1.38 \mathrm{E}-02$ & $6.88 \mathrm{E}-02$ & $1.73 E+00$ & $7.64 \mathrm{E}-01$ \\
\hline & & & 24 & $2.61 \mathrm{E}-03$ & $1.31 \mathrm{E}-02$ & $3.29 \mathrm{E}-01$ & $1.45 \mathrm{E}-01$ \\
\hline & & & 48 & $9.43 E-05$ & $4.72 \mathrm{E}-04$ & $1.19 \mathrm{E}-02$ & $5.24 \mathrm{E}-03$ \\
\hline & & & 96 & $1.23 \mathrm{E}-07$ & $6.14 \mathrm{E}-07$ & $1.55 \mathrm{E}-05$ & $6.82 \mathrm{E}-06$ \\
\hline & & & 120 & $4.43 E-09$ & $2.22 \mathrm{E}-08$ & $5.58 \mathrm{E}-07$ & $2.46 \mathrm{E}-07$ \\
\hline & & & 168 & $5.77 \mathrm{E}-12$ & $2.89 \mathrm{E}-11$ & $7.26 \mathrm{E}-10$ & $3.23 E-10$ \\
\hline & & & 336 & $0.00 \mathrm{E}+00$ & $0.00 \mathrm{E}+00$ & $0.00 \mathrm{E}+00$ & $0.00 \mathrm{E}+00$ \\
\hline & & & 672 & $0.00 \mathrm{E}+00$ & $0.00 \mathrm{E}+00$ & $0.00 \mathrm{E}+00$ & $0.00 \mathrm{E}+00$ \\
\hline \multirow{18}{*}{$\begin{array}{l}\text { Tc-99m DTPA } \\
\text { Aerosol }\end{array}$} & 1 & minimum & 3 & $5.14 \mathrm{E}-05$ & $5.14 \mathrm{E}-03$ & $1.43 E-02$ & $6.09 \mathrm{E}-03$ \\
\hline & & & 12 & $6.98 \mathrm{E}-06$ & $6.98 \mathrm{E}-04$ & $1.94 \mathrm{E}-03$ & $8.26 \mathrm{E}-04$ \\
\hline & & & 24 & $4.87 \mathrm{E}-07$ & $4.87 \mathrm{E}-05$ & $1.35 \mathrm{E}-04$ & $5.76 \mathrm{E}-05$ \\
\hline & & & 48 & $2.37 \mathrm{E}-09$ & $2.37 \mathrm{E}-07$ & $6.57 \mathrm{E}-07$ & $2.80 \mathrm{E}-07$ \\
\hline & & & 96 & $5.60 \mathrm{E}-14$ & $5.60 \mathrm{E}-12$ & $1.55 \mathrm{E}-11$ & $6.63 \mathrm{E}-12$ \\
\hline & & & 120 & $2.72 \mathrm{E}-16$ & $2.72 \mathrm{E}-14$ & $7.55 \mathrm{E}-14$ & $3.22 \mathrm{E}-14$ \\
\hline & & & 168 & $0.00 \mathrm{E}+00$ & $0.00 \mathrm{E}+00$ & $0.00 \mathrm{E}+00$ & $0.00 \mathrm{E}+00$ \\
\hline & & & 336 & $0.00 \mathrm{E}+00$ & $0.00 \mathrm{E}+00$ & $0.00 \mathrm{E}+00$ & $0.00 \mathrm{E}+00$ \\
\hline & & & 672 & $0.00 \mathrm{E}+00$ & $0.00 \mathrm{E}+00$ & $0.00 \mathrm{E}+00$ & $0.00 \mathrm{E}+00$ \\
\hline & & maxmimum & 3 & $9.93 \mathrm{E}-04$ & $9.93 \mathrm{E}-02$ & $2.76 \mathrm{E}-01$ & $1.18 \mathrm{E}-01$ \\
\hline & & & 12 & $2.86 \mathrm{E}-04$ & $2.86 \mathrm{E}-03$ & $7.93 \mathrm{E}-02$ & $3.38 \mathrm{E}-02$ \\
\hline & & & 24 & $5.43 \mathrm{E}-05$ & $5.43 \mathrm{E}-03$ & $1.51 \mathrm{E}-02$ & $6.43 E-03$ \\
\hline & & & 48 & $1.96 \mathrm{E}-06$ & $1.96 \mathrm{E}-04$ & $5.44 \mathrm{E}-04$ & $2.32 \mathrm{E}-04$ \\
\hline & & & 96 & $2.55 \mathrm{E}-09$ & $2.55 \mathrm{E}-07$ & $7.08 \mathrm{E}-07$ & $3.02 \mathrm{E}-07$ \\
\hline & & & 120 & $9.21 \mathrm{E}-11$ & $9.21 \mathrm{E}-09$ & $2.56 \mathrm{E}-08$ & $1.09 \mathrm{E}-08$ \\
\hline & & & 168 & $1.20 \mathrm{E}-13$ & $1.20 \mathrm{E}-11$ & $3.33 \mathrm{E}-11$ & $1.42 \mathrm{E}-11$ \\
\hline & & & 336 & $0.00 \mathrm{E}+00$ & $0.00 \mathrm{E}+00$ & $0.00 \mathrm{E}+00$ & $0.00 \mathrm{E}+00$ \\
\hline & & & 672 & $0.00 \mathrm{E}+00$ & $0.00 \mathrm{E}+00$ & $0.00 \mathrm{E}+00$ & $0.00 \mathrm{E}+00$ \\
\hline
\end{tabular}


Table B.4 Total Activity Ingested and Internal Radiation Doses Received from the Intake of Radiopharmaceuticals in Breast Milk Under Different Interruption Schedules (Continued)

\begin{tabular}{|c|c|c|c|c|c|c|c|}
\hline \multirow{2}{*}{$\begin{array}{l}\text { Radio- } \\
\text { pharmaceutical }\end{array}$} & \multirow{2}{*}{$\begin{array}{c}\text { Administered } \\
\text { Activity } \\
\text { (mCi) }\end{array}$} & \multirow[b]{2}{*}{ Concentration } & \multirow{2}{*}{$\begin{array}{c}\text { Interruption } \\
\text { Time } \\
\text { (hr) }\end{array}$} & \multicolumn{2}{|c|}{$\begin{array}{l}\text { Total Activity } \\
\text { Ingested }\end{array}$} & \multicolumn{2}{|c|}{$\begin{array}{l}\text { Effective Dose Equivalent } \\
\text { (mrem) }\end{array}$} \\
\hline & & & & $(\mathrm{mCi})$ & (\%) & Newborn & 1-Yr-Old \\
\hline Tc-99m & 20 & minimum & 3 & $1.48 \mathrm{E}-02$ & $7.41 \mathrm{E}-02$ & $5.38 \mathrm{E}+00$ & $2.30 \mathrm{E}+00$ \\
\hline \multirow[t]{17}{*}{ Glucoheptonate } & & & 12 & $2.63 E-03$ & $1.31 \mathrm{E}-02$ & $9.52 \mathrm{E}-01$ & $4.08 \mathrm{E}-01$ \\
\hline & & & 24 & $2.61 \mathrm{E}-04$ & $1.31 \mathrm{E}-03$ & $9.48 \mathrm{E}-02$ & $4.06 \mathrm{E}-02$ \\
\hline & & , & 48 & $2.59 \mathrm{E}-06$ & $1.29 \mathrm{E}-05$ & $9.38 \mathrm{E}-04$ & $4.02 E-04$ \\
\hline & & & 96 & $2.53 E-10$ & $1.27 \mathrm{E}-09$ & $9.19 \mathrm{E}-08$ & $3.94 \mathrm{E}-08$ \\
\hline & & & 120 & $2.51 \mathrm{E}-12$ & $1.25 \mathrm{E}-11$ & $9.10 \mathrm{E}-10$ & $3.90 \mathrm{E}-10$ \\
\hline & & & 168 & $2.21 \mathrm{E}-16$ & $1.11 \mathrm{E}-15$ & $8.03 \mathrm{E}-14$ & $3.44 \mathrm{E}-14$ \\
\hline & & & 336 & $0.00 \mathrm{E}+00$ & $0.00 \mathrm{E}+00$ & $0.00 \mathrm{E}+00$ & $0.00 \mathrm{E}+00$ \\
\hline & & & 672 & $0.00 \mathrm{E}+00$ & $0.00 \mathrm{E}+00$ & $0.00 \mathrm{E}+00$ & $0.00 \mathrm{E}+00$ \\
\hline & & maxmimum & 3 & $3.02 E-02$ & $1.51 \mathrm{E}-01$ & $1.10 \mathrm{E}+01$ & $4.70 \mathrm{E}+00$ \\
\hline & & & 12 & $6.37 \mathrm{E}-03$ & $3.19 \mathrm{E}-02$ & $2.31 \mathrm{E}+00$ & $9.90 \mathrm{E}-01$ \\
\hline & & & 24 & $7.99 \mathrm{E}-04$ & $3.99 \mathrm{E}-03$ & $2.90 \mathrm{E}-01$ & $1.24 \mathrm{E}-01$ \\
\hline & & & 48 & $1.25 \mathrm{E}-05$ & $6.27 \mathrm{E}-05$ & $4.55 \mathrm{E}-03$ & $1.95 E-03$ \\
\hline & & & 96 & $3.10 \mathrm{E}-09$ & $1.55 \mathrm{E}-08$ & $1.12 \mathrm{E}-06$ & $4.81 \mathrm{E}-07$ \\
\hline & & & 120 & $4.87 \mathrm{E}-11$ & $2.43 E-10$ & $1.76 \mathrm{E}-08$ & $7.56 \mathrm{E}-09$ \\
\hline & & & 168 & $1.19 \mathrm{E}-14$ & $5.97 \mathrm{E}-14$ & $4.33 \mathrm{E}-12$ & $1.86 \mathrm{E}-12$ \\
\hline & & & 336 & $0.00 \mathrm{E}+00$ & $0.00 \mathrm{E}+00$ & $0.00 \mathrm{E}+00$ & $0.00 \mathrm{E}+00$ \\
\hline & & & 672 & $0.00 \mathrm{E}+00$ & $0.00 \mathrm{E}+00$ & $0.00 \mathrm{E}+00$ & $0.00 \mathrm{E}+00$ \\
\hline \multirow[t]{18}{*}{ Tc-99m HAM } & 8 & minimum & 3 & $3.60 \mathrm{E}-02$ & $4.50 \mathrm{E}-01$ & $2.00 \mathrm{E}+01$ & $8.13 E+00$ \\
\hline & & & 12 & $4.51 \mathrm{E}-03$ & $5.64 \mathrm{E}-02$ & $2.50 \mathrm{E}+00$ & $1.02 \mathrm{E}+00$ \\
\hline & & & 24 & $2.83 E-04$ & $3.54 \mathrm{E}-03$ & $1.57 \mathrm{E}-01$ & $6.38 \mathrm{E}-02$ \\
\hline & & & 48 & $1.11 \mathrm{E}-06$ & $1.39 \mathrm{E}-05$ & $6.17 \mathrm{E}-04$ & $2.51 E-04$ \\
\hline & & & 96 & $1.72 \mathrm{E}-11$ & $2.14 \mathrm{E}-10$ & $9.52 \mathrm{E}-09$ & $3.87 \mathrm{E}-09$ \\
\hline & & & 120 & $6.73 E-14$ & $8.42 \mathrm{E}-13$ & $3.74 \mathrm{E}-11$ & $1.52 \mathrm{E}-11$ \\
\hline & & & 168 & $0.00 \mathrm{E}+00$ & $0.00 \mathrm{E}+00$ & $0.00 \mathrm{E}+00$ & $0.00 \mathrm{E}+00$ \\
\hline & & & 336 & $0.00 \mathrm{E}+00$ & $0.00 \mathrm{E}+00$ & $0.00 \mathrm{E}+00$ & $0.00 \mathrm{E}+00$ \\
\hline & & & 672 & $0.00 \mathrm{E}+00$ & $0.00 \mathrm{E}+00$ & $0.00 \mathrm{E}+00$ & $0.00 \mathrm{E}+00$ \\
\hline & & maxmimum & 3 & $8.95 \mathrm{E}-02$ & $1.12 \mathrm{E}+00$ & $4.97 \mathrm{E}+01$ & $2.02 E+01$ \\
\hline & & & 12 & $3.67 \mathrm{E}-02$ & $4.59 \mathrm{E}-01$ & $2.04 \mathrm{E}+01$ & $8.29 \mathrm{E}+00$ \\
\hline & & & 24 & $1.12 \mathrm{E}-02$ & $1.40 \mathrm{E}-01$ & $6.21 \mathrm{E}+00$ & $2.53 \mathrm{E}+00$ \\
\hline & & & 48 & $1.04 \mathrm{E}-03$ & $1.30 \mathrm{E}-02$ & $5.77 \mathrm{E}-01$ & $2.35 \mathrm{E}-01$ \\
\hline & & & 96 & $8.98 \mathrm{E}-06$ & $1.12 \mathrm{E}-04$ & $4.98 \mathrm{E}-03$ & $2.03 E-03$ \\
\hline & & & 120 & $8.35 E-07$ & $1.04 \mathrm{E}-05$ & $4.63 \mathrm{E}-04$ & $1.88 \mathrm{E}-04$ \\
\hline & & & 168 & $7.21 \mathrm{E}-09$ & $9.01 \mathrm{E}-08$ & $4.00 \mathrm{E}-06$ & $1.63 \mathrm{E}-06$ \\
\hline & & & 336 & $3.00 \mathrm{E}-16$ & $3.75 \mathrm{E}-15$ & $1.66 \mathrm{E}-13$ & $6.76 \mathrm{E}-14$ \\
\hline & & & 672 & $0.00 \mathrm{E}+00$ & $0.00 \mathrm{E}+00$ & $0.00 \mathrm{E}+00$ & $0.00 \mathrm{E}+00$ \\
\hline
\end{tabular}


Table B.4 Total Activity Ingested and Internal Radiation Doses Received from the Intake of Radiopharmaceuticals in Breast Milk Under Different Interruption Schedules (Continued)

\begin{tabular}{|c|c|c|c|c|c|c|c|}
\hline \multirow{2}{*}{$\begin{array}{l}\text { Radio- } \\
\text { pharmaceutical }\end{array}$} & \multirow{2}{*}{$\begin{array}{l}\text { Administered } \\
\text { Activity } \\
\text { (mCi) }\end{array}$} & \multirow[b]{2}{*}{ Concentration } & \multirow{2}{*}{$\begin{array}{c}\text { Interruption } \\
\text { Time } \\
\text { (hr) }\end{array}$} & \multicolumn{2}{|c|}{$\begin{array}{l}\text { Total Activity } \\
\text { Ingested }\end{array}$} & \multicolumn{2}{|c|}{$\begin{array}{c}\text { Effective Dose Equivalent } \\
\text { (mrem) }\end{array}$} \\
\hline & & & & $(\mathrm{mCi})$ & (\%) & Newborn & 1-Yr-Old \\
\hline \multirow[t]{18}{*}{ Tc-99m MAA } & 4 & minimum & 3 & $6.66 \mathrm{E}-03$ & $1.66 \mathrm{E}-01$ & $4.19 \mathrm{E}+00$ & $1.70 \mathrm{E}+00$ \\
\hline & . & & 12 & $7.11 \mathrm{E}-04$ & $1.78 \mathrm{E}-02$ & $4.47 \mathrm{E}-01$ & $1.81 \mathrm{E}-01$ \\
\hline & & & 24 & $3.60 \mathrm{E}-05$ & $9.00 \mathrm{E}-04$ & $2.26 \mathrm{E}-02$ & $9.19 \mathrm{E}-03$ \\
\hline & & & 48 & $9.23 \mathrm{E}-08$ & $2.31 E-06$ & $5.81 \mathrm{E}-05$ & $2.36 \mathrm{E}-05$ \\
\hline & & & 96 & $6.07 \mathrm{E}-13$ & $1.52 \mathrm{E}-11$ & $3.82 E-10$ & $1.55 \mathrm{E}-10$ \\
\hline & & & 120 & $1.54 \mathrm{E}-15$ & $3.85 \mathrm{E}-14$ & $9.69 \mathrm{E}-13$ & $3.93 E-13$ \\
\hline & & & 168 & $0.00 \mathrm{E}+00$ & $0.00 \mathrm{E}+00$ & $0.00 \mathrm{E}+00$ & $0.00 \mathrm{E}+00$ \\
\hline & & - & 336 & $0.00 \mathrm{E}+00$ & $0.00 \mathrm{E}+00$ & $0.00 \mathrm{E}+00$ & $0.00 \mathrm{E}+00$ \\
\hline & & & 672 & $0.00 \mathrm{E}+00$ & $0.00 \mathrm{E}+00$ & $0.00 \mathrm{E}+00$ & $0.00 \mathrm{E}+00$ \\
\hline & & maxmimum & 3 & $4.78 \mathrm{E}-01$ & $1.19 \mathrm{E}+01$ & $3.01 \mathrm{E}+02$ & $1.22 \mathrm{E}+02$ \\
\hline & & & 12 & $1.47 \mathrm{E}-01$ & $3.68 \mathrm{E}+01$ & $9.27 \mathrm{E}+01$ & $3.76 \mathrm{E}+01$ \\
\hline & & & 24 & $3.07 \mathrm{E}-02$ & $7.68 \mathrm{E}-01$ & $1.93 \mathrm{E}+01$ & $7.84 \mathrm{E}+00$ \\
\hline & & & 48 & $1.33 E-03$ & $3.33 E-02$ & $8.38 \mathrm{E}-01$ & $3.40 \mathrm{E}-01$ \\
\hline & & & 96 & $2.51 \mathrm{E}-06$ & $6.28 \mathrm{E}-05$ & $1.58 \mathrm{E}-03$ & $6.41 E-04$ \\
\hline & & & 120 & $1.09 \mathrm{E}-07$ & $2.73 E-06$ & $6.86 \mathrm{E}-05$ & $2.78 \mathrm{E}-05$ \\
\hline & & & 168 & $2.06 \mathrm{E}-10$ & $5.14 \mathrm{E}-09$ & $1.29 \mathrm{E}-07$ & $5.25 \mathrm{E}-08$ \\
\hline & & & 336 & $0.00 \mathrm{E}+00$ & $0.00 \mathrm{E}+00$ & $0.00 E+00$ & $0.00 \mathrm{E}+00$ \\
\hline & & & 672 & $0.00 \mathrm{E}+00$ & $0.00 \mathrm{E}+00$ & $0.00 \mathrm{E}+00$ & $0.00 \mathrm{E}+00$ \\
\hline \multirow[t]{18}{*}{ Tc-99m MAG3 } & 10 & minimum & 3 & $1.29 \mathrm{E}-03$ & $1.29 \mathrm{E}-02$ & $1.52 \mathrm{E}-01$ & $6.66 \mathrm{E}-02$ \\
\hline & & & 12 & $1.74 \mathrm{E}-04$ & $1.74 \mathrm{E}-03$ & $2.07 \mathrm{E}-02$ & $9.04 \mathrm{E}-03$ \\
\hline & & & 24 & $1.22 \mathrm{E}-05$ & $1.22 \mathrm{E}-04$ & $1.44 \mathrm{E}-03$ & $6.30 \mathrm{E}-04$ \\
\hline & & & 48 & $5.92 \mathrm{E}-08$ & $5.92 \mathrm{E}-07$ & $7.00 \mathrm{E}-06$ & $3.06 \mathrm{E}-06$ \\
\hline & & & 96 & $1.40 \mathrm{E}-12$ & $1.40 \mathrm{E}-11$ & $1.66 \mathrm{E}-10$ & $7.25 \mathrm{E}-11$ \\
\hline & & & 120 & $6.80 \mathrm{E}-15$ & $6.80 \mathrm{E}-14$ & $8.05 E-13$ & $3.52 \mathrm{E}-13$ \\
\hline & & & 168 & $0.00 \mathrm{E}+00$ & $0.00 \mathrm{E}+00$ & $0.00 \mathrm{E}+00$ & $0.00 \mathrm{E}+00$ \\
\hline & & & 336 & $0.00 \mathrm{E}+00$ & $0.00 \mathrm{E}+00$ & $0.00 \mathrm{E}+00$ & $0.00 \mathrm{E}+00$ \\
\hline & & & 672 & $0.00 \mathrm{E}+00$ & $0.00 \mathrm{E}+00$ & $0.00 \mathrm{E}+00$ & $0.00 \mathrm{E}+00$ \\
\hline & & maxmimum & 3 & $2.39 \mathrm{E}-02$ & $2.39 \mathrm{E}-01$ & $2.83 E+00$ & $1.24 \mathrm{E}+00$ \\
\hline & & & 12 & $6.88 \mathrm{E}-03$ & $6.88 \mathrm{E}-02$ & $8.15 \mathrm{E}-01$ & $3.56 \mathrm{E}-01$ \\
\hline & & & 24 & $1.31 \mathrm{E}-03$ & $1.31 \mathrm{E}-02$ & $1.55 \mathrm{E}-01$ & $6.77 \mathrm{E}-02$ \\
\hline & & & 48 & $4.72 \mathrm{E}-05$ & $4.72 \mathrm{E}-04$ & $5.58 \mathrm{E}-03$ & $2.44 \mathrm{E}-03$ \\
\hline & & & 96 & $6.14 \mathrm{E}-08$ & $6.14 \mathrm{E}-07$ & $7.27 \mathrm{E}-06$ & $3.18 \mathrm{E}-06$ \\
\hline & & & 120 & $2.22 \mathrm{E}-09$ & $2.22 \mathrm{E}-08$ & $2.62 E-07$ & $1.15 E-07$ \\
\hline & & & 168 & $2.89 \mathrm{E}-12$ & $2.89 \mathrm{E}-11$ & $3.42 \mathrm{E}-10$ & $1.50 \mathrm{E}-10$ \\
\hline & & & 336 & $0.00 \mathrm{E}+00$ & $0.00 \mathrm{E}+00$ & $0.00 \mathrm{E}+00$ & $0.00 \mathrm{E}+00$ \\
\hline & & & 672 & $0.00 \mathrm{E}+00$ & $0.00 \mathrm{E}+00$ & $0.00 \mathrm{E}+00$ & $0.00 \mathrm{E}+00$ \\
\hline
\end{tabular}


Table B.4 Total Activity Ingested and Internal Radiation Doses Received from the Intake of Radiopharmaceuticals in Breast Milk Under Different Interruption Schedules (Continued)

\begin{tabular}{|c|c|c|c|c|c|c|c|}
\hline \multirow{2}{*}{$\begin{array}{l}\text { Radio- } \\
\text { pharmaceutical }\end{array}$} & \multirow{2}{*}{$\begin{array}{l}\text { Administered } \\
\text { Activity } \\
\text { (mCi) }\end{array}$} & \multirow[b]{2}{*}{ Concentration } & \multirow{2}{*}{$\begin{array}{c}\text { Interruption } \\
\text { Time } \\
\text { (hr) }\end{array}$} & \multicolumn{2}{|c|}{$\begin{array}{l}\text { Total Activity } \\
\text { Ingested }\end{array}$} & \multicolumn{2}{|c|}{$\begin{array}{l}\text { Effective Dose Equivalent } \\
\text { (mrem) }\end{array}$} \\
\hline & & & & $(\mathrm{mCi})$ & (\%) & Newborn & 1-Yr-Old \\
\hline \multirow[t]{18}{*}{ Tc-99m MDP } & \multirow[t]{18}{*}{20} & \multirow[t]{9}{*}{ minimum } & 3 & $8.94 \mathrm{E}-03$ & $4.47 \mathrm{E}-02$ & $3.64 \mathrm{E}+00$ & $1.39 \mathrm{E}+00$ \\
\hline & & & 12 & $1.51 \mathrm{E}-03$ & $7.53 \mathrm{E}-03$ & $6.13 E-01$ & $2.34 \mathrm{E}-01$ \\
\hline & & & 24 & $1.40 \mathrm{E}-04$ & $7.02 \mathrm{E}-04$ & $5.71 \mathrm{E}-02$ & $2.18 \mathrm{E}-02$ \\
\hline & & & 48 & $1.22 \mathrm{E}-06$ & $6.09 \mathrm{E}-06$ & $4.95 \mathrm{E}-04$ & $1.89 \mathrm{E}-04$ \\
\hline & & & 96 & $9.16 \mathrm{E}-11$ & $4.58 \mathrm{E}-10$ & $3.73 E-08$ & $1.42 \mathrm{E}-08$ \\
\hline & & & 120 & $7.94 \mathrm{E}-13$ & $3.97 \mathrm{E}-12$ & $3.23 \mathrm{E}-10$ & $1.23 \mathrm{E}-10$ \\
\hline & & & 168 & $4.15 E-17$ & $2.08 \mathrm{E}-16$ & $1.69 \mathrm{E}-14$ & $6.45 \mathrm{E}-15$ \\
\hline & & & 336 & $0.00 \mathrm{E}+00$ & $0.00 \mathrm{E}+00$ & $0.00 \mathrm{E}+00$ & $0.00 \mathrm{E}+00$ \\
\hline & & & 672 & $0.00 \mathrm{E}+00$ & $0.00 \mathrm{E}+00$ & $0.00 \mathrm{E}+00$ & $0.00 \mathrm{E}+00$ \\
\hline & & \multirow[t]{9}{*}{ maxmimum } & 3 & $1.20 \mathrm{E}-02$ & $5.98 \mathrm{E}-02$ & $4.87 \mathrm{E}+00$ & $1.86 \mathrm{E}+00$ \\
\hline & & & 12 & $3.53 E-03$ & $1.76 \mathrm{E}-02$ & $1.44 \mathrm{E}+00$ & $5.48 \mathrm{E}-01$ \\
\hline & & & 24 & $6.92 \mathrm{E}-04$ & $3.46 \mathrm{E}-03$ & $2.82 \mathrm{E}-01$ & $1.08 \mathrm{E}-01$ \\
\hline & & & 48 & $2.67 \mathrm{E}-05$ & $1.33 \mathrm{E}-04$ & $1.09 \mathrm{E}-02$ & $4.14 \mathrm{E}-03$ \\
\hline & & & 96 & $3.96 \mathrm{E}-08$ & $1.98 \mathrm{E}-07$ & $1.61 \mathrm{E}-05$ & $6.15 \mathrm{E}-06$ \\
\hline & & & 120 & $1.52 \mathrm{E}-09$ & $7.62 \mathrm{E}-09$ & $6.20 \mathrm{E}-07$ & $2.37 \mathrm{E}-07$ \\
\hline & & & 168 & $2.26 \mathrm{E}-12$ & $1.13 \mathrm{E}-11$ & $9.20 \mathrm{E}-10$ & $3.51 \mathrm{E}-10$ \\
\hline & & & 336 & $0.00 \mathrm{E}+00$ & $0.00 \mathrm{E}+00$ & $0.00 \mathrm{E}+00$ & $0.00 \mathrm{E}+00$ \\
\hline & & & 672 & $0.00 \mathrm{E}+00$ & $0.00 \mathrm{E}+00$ & $0.00 \mathrm{E}+00$ & $0.00 \mathrm{E}+00$ \\
\hline \multirow[t]{18}{*}{ Tc-99m MIBI } & \multirow[t]{18}{*}{30} & \multirow[t]{9}{*}{ minimum } & 3 & $2.23 \mathrm{E}-03$ & $7.44 \mathrm{E}-03$ & $1.16 \mathrm{E}+00$ & $5.37 \mathrm{E}-01$ \\
\hline & & & 12 & $5.59 \mathrm{E}-04$ & $1.86 \mathrm{E}-03$ & $2.90 \mathrm{E}-01$ & $1.34 \mathrm{E}-01$ \\
\hline & & & 24 & $8.83 E-05$ & $2.94 \mathrm{E}-04$ & $4.57 \mathrm{E}-02$ & $2.12 \mathrm{E}-02$ \\
\hline & & & 48 & $2.20 \mathrm{E}-06$ & $7.34 \mathrm{E}-06$ & $1.14 \mathrm{E}-03$ & $5.30 \mathrm{E}-04$ \\
\hline & & & 96 & $1.37 \mathrm{E}-09$ & $4.56 \mathrm{E}-09$ & $7.09 \mathrm{E}-07$ & $3.29 \mathrm{E}-07$ \\
\hline & & & 120 & $3.41 \mathrm{E}-11$ & $1.14 \mathrm{E}-10$ & $1.77 \mathrm{E}-08$ & $8.21 E-09$ \\
\hline & & & 168 & $2.12 \mathrm{E}-14$ & $7.08 \mathrm{E}-14$ & $1.10 \mathrm{E}-11$ & $5.11 \mathrm{E}-12$ \\
\hline & & & 336 & $0.00 \mathrm{E}+00$ & $0.00 \mathrm{E}+00$ & $0.00 \mathrm{E}+00$ & $0.00 \mathrm{E}+00$ \\
\hline & & & 672 & $0.00 \mathrm{E}+00$ & $0.00 \mathrm{E}+00$ & $0.00 \mathrm{E}+00$ & $0.00 \mathrm{E}+00$ \\
\hline & & \multirow[t]{9}{*}{ maxmimum } & 3 & $1.97 \mathrm{E}-02$ & $6.56 \mathrm{E}-02$ & $1.02 E+01$ & $4.73 E+00$ \\
\hline & & & 12 & $7.76 \mathrm{E}-03$ & $2.59 \mathrm{E}-02$ & $4.02 \mathrm{E}+00$ & $1.87 \mathrm{E}+00$ \\
\hline & & & 24 & $2.24 \mathrm{E}-03$ & $7.47 \mathrm{E}-03$ & $1.16 \mathrm{E}+00$ & $5.39 \mathrm{E}-01$ \\
\hline & & & 48 & $1.87 \mathrm{E}-04$ & $6.24 \mathrm{E}-04$ & $9.70 \mathrm{E}-02$ & $4.51 \mathrm{E}-02$ \\
\hline & & & 96 & $1.31 \mathrm{E}-06$ & $4.36 \mathrm{E}-06$ & $6.77 \mathrm{E}-04$ & $3.14 \mathrm{E}-04$ \\
\hline & & & 120 & $1.09 \mathrm{E}-07$ & $3.64 \mathrm{E}-07$ & $5.66 \mathrm{E}-05$ & $2.63 \mathrm{E}-05$ \\
\hline & & & 168 & $7.62 \mathrm{E}-10$ & $2.54 \mathrm{E}-09$ & $3.95 \mathrm{E}-07$ & $1.83 \mathrm{E}-07$ \\
\hline & & & 336 & $0.00 \mathrm{E}+00$ & $0.00 \mathrm{E}+00$ & $0.00 \mathrm{E}+00$ & $0.00 \mathrm{E}+00$ \\
\hline & & & 672 & $0.00 \mathrm{E}+00$ & $0.00 \mathrm{E}+00$ & $0.00 \mathrm{E}+00$ & $0.00 \mathrm{E}+00$ \\
\hline
\end{tabular}


Table B.4 Total Activity Ingested and Internal Radiation Doses Received from the Intake of Radiopharmaceuticals in Breast Milk Under Different Interruption Schedules (Continued)

\begin{tabular}{|c|c|c|c|c|c|c|c|}
\hline \multirow{2}{*}{$\begin{array}{l}\text { Radio- } \\
\text { pharmaceutical }\end{array}$} & \multirow{2}{*}{$\begin{array}{l}\text { Administered } \\
\text { Activity } \\
\text { (mCi) }\end{array}$} & \multirow[b]{2}{*}{ Concentration } & \multirow{2}{*}{$\begin{array}{l}\text { Interruption } \\
\text { Time } \\
\text { (hr) }\end{array}$} & \multicolumn{2}{|c|}{$\begin{array}{l}\text { Total Activity } \\
\text { Ingested }\end{array}$} & \multicolumn{2}{|c|}{$\begin{array}{c}\text { Effective Dose Equivalen } \\
\text { (mrem) }\end{array}$} \\
\hline & & & & $(\mathrm{mCi})$ & (\%) & Newborn & 1-Yr-Old \\
\hline \multirow{18}{*}{$\begin{array}{l}\mathrm{Tc}-99 \mathrm{~m} \mathrm{O}_{4} \\
\text { (Pertechnetate) }\end{array}$} & 30 & minimum & 3 & $4.78 \mathrm{E}-02$ & $1.59 \mathrm{E}-01$ & $1.95 E+01$ & $9.02 E+00$ \\
\hline & & & 12 & $5.10 \mathrm{E}-03$ & $1.70 \mathrm{E}-02$ & $2.08 \mathrm{E}+00$ & $9.63 E-01$ \\
\hline & & & 24 & $2.58 \mathrm{E}-04$ & $8.61 \mathrm{E}-04$ & $1.05 \mathrm{E}-01$ & $4.88 \mathrm{E}-02$ \\
\hline & & & 48 & $6.63 E-07$ & $2.21 E-06$ & $2.70 \mathrm{E}-04$ & $1.25 \mathrm{E}-04$ \\
\hline & & & 96 & $4.36 \mathrm{E}-12$ & $1.45 \mathrm{E}-11$ & $1.77 \mathrm{E}-09$ & $8.23 E-10$ \\
\hline & & & 120 & $1.11 \mathrm{E}-14$ & $3.69 \mathrm{E}-14$ & $4.50 \mathrm{E}-12$ & $2.09 \mathrm{E}-12$ \\
\hline & & & 168 & $0.00 \mathrm{E}+00$ & $0.00 \mathrm{E}+00$ & $0.00 \mathrm{E}+00$ & $0.00 \mathrm{E}+00$ \\
\hline & & & 336 & $0.00 \mathrm{E}+00$ & $0.00 \mathrm{E}+00$ & $0.00 \mathrm{E}+00$ & $0.00 \mathrm{E}+00$ \\
\hline & & & 672 & $0.00 \mathrm{E}+00$ & $0.00 \mathrm{E}+00$ & $0.00 \mathrm{E}+00$ & $0.00 \mathrm{E}+00$ \\
\hline & & maxmimum & 3 & $2.03 \mathrm{E}+00$ & $6.76 \mathrm{E}+00$ & $8.25 E+02$ & $3.83 \mathrm{E}+02$ \\
\hline & & & 12 & $6.54 \mathrm{E}-01$ & $2.18 \mathrm{E}+00$ & $2.66 \mathrm{E}+02$ & $1.23 E+02$ \\
\hline & & & 24 & $1.44 \mathrm{E}-01$ & $4.81 \mathrm{E}-01$ & $5.88 \mathrm{E}+01$ & $2.73 E+01$ \\
\hline & & & 48 & $7.05 \mathrm{E}-03$ & $2.35 E-02$ & $2.87 \mathrm{E}+00$ & $1.33 \mathrm{E}+00$ \\
\hline & & & 96 & $1.68 \mathrm{E}-05$ & $5.61 \mathrm{E}-05$ & $6.84 \mathrm{E}-03$ & $3.17 \mathrm{E}-03$ \\
\hline & & & 120 & $8.21 E-07$ & $2.74 \mathrm{E}-06$ & $3.34 \mathrm{E}-04$ & $1.55 \mathrm{E}-04$ \\
\hline & & & 168 & $1.96 \mathrm{E}-09$ & $6.53 \mathrm{E}-09$ & $7.97 \mathrm{E}-07$ & $3.69 \mathrm{E}-07$ \\
\hline & & & 336 & $0.00 \mathrm{E}+00$ & $0.00 \mathrm{E}+00$ & $0.00 \mathrm{E}+00$ & $0.00 \mathrm{E}+00$ \\
\hline & & & 672 & $0.00 \mathrm{E}+00$ & $0.00 \mathrm{E}+00$ & $0.00 \mathrm{E}+00$ & $0.00 \mathrm{E}+00$ \\
\hline \multirow[t]{18}{*}{ Tc-99m PYP } & 20 & minimum & 3 & $1.73 E-02$ & $8.66 \mathrm{E}-02$ & $4.81 E+00$ & $2.05 E+00$ \\
\hline & & & 12 & $2.92 \mathrm{E}-03$ & $1.46 \mathrm{E}-02$ & $8.10 \mathrm{E}-01$ & $3.46 \mathrm{E}-01$ \\
\hline & & & 24 & $2.72 \mathrm{E}-04$ & $1.36 \mathrm{E}-03$ & $7.55 \mathrm{E}-02$ & $3.22 \mathrm{E}-02$ \\
\hline & & & 48 & $2.36 \mathrm{E}-06$ & $1.18 \mathrm{E}-05$ & $6.54 \mathrm{E}-04$ & $2.79 \mathrm{E}-04$ \\
\hline & & & 96 & $1.77 \mathrm{E}-10$ & $8.87 E-10$ & $4.92 \mathrm{E}-08$ & $2.10 \mathrm{E}-08$ \\
\hline & & & 120 & $1.54 \mathrm{E}-12$ & $7.70 \mathrm{E}-12$ & $4.27 \mathrm{E}-10$ & $1.82 \mathrm{E}-10$ \\
\hline & & & 168 & $8.05 \mathrm{E}-17$ & $4.02 \mathrm{E}-16$ & $2.23 E-14$ & $9.53 \mathrm{E}-15$ \\
\hline & & & 336 & $0.00 \mathrm{E}+00$ & $0.00 \mathrm{E}+00$ & $0.00 \mathrm{E}+00$ & $0.00 \mathrm{E}+00$ \\
\hline & & & 672 & $0.00 \mathrm{E}+00$ & $0.00 \mathrm{E}+00$ & $0.00 \mathrm{E}+00$ & $0.00 \mathrm{E}+00$ \\
\hline & & maxmimum & 3 & $8.73 \mathrm{E}-02$ & $4.37 \mathrm{E}-01$ & $2.42 \mathrm{E}+01$ & $1.03 E+01$ \\
\hline & & & 12 & $3.49 \mathrm{E}-02$ & $1.74 \mathrm{E}-01$ & $9.68 \mathrm{E}+00$ & $4.13 E+00$ \\
\hline & & & 24 & $1.03 \mathrm{E}-02$ & $5.14 \mathrm{E}-02$ & $2.85 \mathrm{E}+00$ & $1.22 \mathrm{E}+00$ \\
\hline & & & 48 & $8.90 \mathrm{E}-04$ & $4.45 \mathrm{E}-03$ & $2.47 \mathrm{E}-01$ & $1.05 \mathrm{E}-01$ \\
\hline & & & 96 & $6.68 \mathrm{E}-06$ & $3.34 \mathrm{E}-05$ & $1.85 \mathrm{E}-03$ & $7.91 \mathrm{E}-04$ \\
\hline & & & 120 & $5.79 \mathrm{E}-07$ & $2.90 \mathrm{E}-06$ & $1.61 \mathrm{E}-04$ & $6.86 \mathrm{E}-05$ \\
\hline & & & 168 & $4.35 \mathrm{E}-09$ & $2.17 \mathrm{E}-08$ & $1.21 \mathrm{E}-06$ & $5.15 \mathrm{E}-07$ \\
\hline & & & 336 & $4.20 \mathrm{E}-17$ & $2.10 \mathrm{E}-16$ & $1.17 \mathrm{E}-14$ & $4.97 \mathrm{E}-15$ \\
\hline & & & 672 & $0.00 \mathrm{E}+00$ & $0.00 \mathrm{E}+00$ & $0.00 \mathrm{E}+00$ & $0.00 \mathrm{E}+00$ \\
\hline
\end{tabular}


Table B.4 Total Activity Ingested and Internal Radiation Doses Received from the Intake of Radiopharmaceuticals in Breast Milk Under Different Interruption Schedules (Continued)

\begin{tabular}{|c|c|c|c|c|c|c|c|}
\hline \multirow{2}{*}{$\begin{array}{l}\text { Radio- } \\
\text { pharmaceutical }\end{array}$} & \multirow{2}{*}{$\begin{array}{l}\text { Administered } \\
\text { Activity } \\
\text { (mCi) }\end{array}$} & \multirow{2}{*}{ Concentration } & \multirow{2}{*}{$\begin{array}{l}\text { Interruption } \\
\text { Time } \\
\text { (hr) }\end{array}$} & \multicolumn{2}{|c|}{$\begin{array}{l}\text { Total Activity } \\
\text { Ingested }\end{array}$} & \multicolumn{2}{|c|}{$\begin{array}{c}\text { Effective Dose Equivalent } \\
\text { (mrem) }\end{array}$} \\
\hline & & & & $(\mathrm{mCi})$ & (\%) & Newborn & 1-Yr-Old \\
\hline Tc-99m RBC & 20 & minimum & 3 & $3.53 E-03$ & $1.76 \mathrm{E}-02$ & $1.10 \mathrm{E}+00$ & $4.83 \mathrm{E}-01$ \\
\hline \multirow[t]{17}{*}{ In Vitro Labeling } & & & 12 & $1.58 \mathrm{E}-03$ & $7.92 \mathrm{E}-03$ & $4.93 \mathrm{E}-01$ & $2.17 \mathrm{E}-01$ \\
\hline & & & 24 & $5.46 \mathrm{E}-04$ & $2.73 E-03$ & $1.70 \mathrm{E}-01$ & $7.47 \mathrm{E}-02$ \\
\hline & , & & 48 & $6.47 \mathrm{E}-05$ & $3.24 \mathrm{E}-04$ & $2.01 E-02$ & $8.86 \mathrm{E}-03$ \\
\hline & & & 96 & $9.10 \mathrm{E}-07$ & $4.55 \mathrm{E}-06$ & $2.83 E-04$ & $1.25 \mathrm{E}-04$ \\
\hline & & & 120 & $1.08 \mathrm{E}-07$ & $5.39 \mathrm{E}-07$ & $3.35 \mathrm{E}-05$ & $1.48 \mathrm{E}-05$ \\
\hline & & & 168 & $1.52 \mathrm{E}-09$ & $7.58 \mathrm{E}-09$ & $4.71 \mathrm{E}-07$ & $2.08 \mathrm{E}-07$ \\
\hline & & & 336 & $4.95 \mathrm{E}-16$ & $2.48 \mathrm{E}-15$ & $1.54 \mathrm{E}-13$ & $6.78 \mathrm{E}-14$ \\
\hline & & & 672 & $0.00 \mathrm{E}+00$ & $0.00 \mathrm{E}+00$ & $0.00 \mathrm{E}+00$ & $0.00 \mathrm{E}+00$ \\
\hline & & maxmimum & 3 & $6.06 \mathrm{E}-03$ & $3.03 E-02$ & $1.88 \mathrm{E}+00$ & $8.30 \mathrm{E}-01$ \\
\hline & & & 12 & $3.03 E-03$ & $1.52 \mathrm{E}-02$ & $9.42 \mathrm{E}-01$ & $4.15 \mathrm{E}-01$ \\
\hline & & & 24 & $1.20 \mathrm{E}-03$ & $6.01 \mathrm{E}-03$ & $3.74 \mathrm{E}-01$ & $1.65 \mathrm{E}-01$ \\
\hline & & & 48 & $1.90 \mathrm{E}-04$ & $9.48 \mathrm{E}-04$ & $5.89 \mathrm{E}-02$ & $2.59 \mathrm{E}-02$ \\
\hline & & & 96 & $4.70 \mathrm{E}-06$ & $2.35 \mathrm{E}-05$ & $1.46 \mathrm{E}-03$ & $6.44 \mathrm{E}-04$ \\
\hline & & & 120 & $7.41 \mathrm{E}-07$ & $3.71 \mathrm{E}-06$ & $2.30 \mathrm{E}-04$ & $1.01 \mathrm{E}-04$ \\
\hline & & & 168 & $1.84 \mathrm{E}-08$ & $9.20 \mathrm{E}-08$ & $5.72 \mathrm{E}-06$ & $2.52 \mathrm{E}-06$ \\
\hline & & & 336 & $4.43 E-14$ & $2.22 \mathrm{E}-13$ & $1.38 \mathrm{E}-11$ & $6.07 \mathrm{E}-12$ \\
\hline & & & 672 & $0.00 \mathrm{E}+00$ & $0.00 \mathrm{E}+00$ & $0.00 \mathrm{E}+00$ & $0.00 \mathrm{E}+00$ \\
\hline Tc-99m RBC & 20 & minimum & 3 & $9.49 \mathrm{E}-04$ & $4.75 \mathrm{E}-03$ & $2.88 \mathrm{E}-01$ & $1.30 \mathrm{E}-01$ \\
\hline \multirow[t]{17}{*}{ In Vivo Labeling } & & & 12 & $3.79 \mathrm{E}-04$ & $1.90 \mathrm{E}-03$ & $1.15 \mathrm{E}-01$ & $5.19 \mathrm{E}-02$ \\
\hline & & & 24 & $1.12 \mathrm{E}-04$ & $5.58 \mathrm{E}-04$ & $3.39 \mathrm{E}-02$ & $1.53 \mathrm{E}-02$ \\
\hline & & & 48 & $9.67 \mathrm{E}-06$ & $4.84 \mathrm{E}-05$ & $2.94 \mathrm{E}-03$ & $1.32 \mathrm{E}-03$ \\
\hline & & & 96 & $7.26 \mathrm{E}-08$ & $3.63 \mathrm{E}-07$ & $2.20 \mathrm{E}-05$ & $9.94 \mathrm{E}-06$ \\
\hline & & & 120 & $6.29 \mathrm{E}-09$ & $3.15 \mathrm{E}-08$ & $1.91 E-06$ & $8.62 \mathrm{E}-07$ \\
\hline & & & 168 & $4.73 E-11$ & $2.36 \mathrm{E}-10$ & $1.43 \mathrm{E}-08$ & $6.47 \mathrm{E}-09$ \\
\hline & & & 336 & $4.57 \mathrm{E}-19$ & $2.28 \mathrm{E}-18$ & $1.39 \mathrm{E}-16$ & $6.25 \mathrm{E}-17$ \\
\hline & & & 672 & $0.00 \mathrm{E}+00$ & $0.00 \mathrm{E}+00$ & $0.00 \mathrm{E}+00$ & $0.00 \mathrm{E}+00$ \\
\hline & & maxmimum & 3 & $4.38 \mathrm{E}-01$ & $2.19 \mathrm{E}+00$ & $1.33 E+02$ & $5.99 \mathrm{E}+01$ \\
\hline & & & 12 & $1.80 \mathrm{E}-01$ & $8.98 \mathrm{E}-01$ & $5.45 \mathrm{E}+01$ & $2.46 \mathrm{E}+01$ \\
\hline & & & 24 & $5.48 \mathrm{E}-02$ & $2.74 \mathrm{E}-01$ & $1.66 \mathrm{E}+01$ & $7.50 \mathrm{E}+00$ \\
\hline & & & 48 & $5.09 \mathrm{E}-03$ & $2.54 \mathrm{E}-02$ & $1.54 \mathrm{E}+00$ & $6.96 \mathrm{E}-01$ \\
\hline & & & 96 & $4.39 E-05$ & $2.20 \mathrm{E}-04$ & $1.33 E-02$ & $6.01 E-03$ \\
\hline & & & 120 & $4.08 \mathrm{E}-06$ & $2.04 \mathrm{E}-05$ & $1.24 \mathrm{E}-03$ & $5.59 \mathrm{E}-04$ \\
\hline & & & 168 & $3.52 E-08$ & $1.76 \mathrm{E}-07$ & $1.07 \mathrm{E}-05$ & $4.82 \mathrm{E}-06$ \\
\hline & & & 336 & $1.47 \mathrm{E}-15$ & $7.33 \mathrm{E}-15$ & $4.45 \mathrm{E}-13$ & $2.01 E-13$ \\
\hline & & & 672 & $0.00 \mathrm{E}+00$ & $0.00 \mathrm{E}+00$ & $0.00 \mathrm{E}+00$ & $0.00 \mathrm{E}+00$ \\
\hline
\end{tabular}


Table B.4 Total Activity Ingested and Internal Radiation Doses Received from the Intake of Radiopharmaceuticals in Breast Milk Under Different Interruption Schedules (Continued)

\begin{tabular}{|c|c|c|c|c|c|c|c|}
\hline \multirow{2}{*}{$\begin{array}{l}\text { Radio- } \\
\text { pharmaceutical }\end{array}$} & \multirow{2}{*}{$\begin{array}{l}\text { Administered } \\
\text { Activity } \\
\text { (mCi) }\end{array}$} & \multirow[b]{2}{*}{ Concentration } & \multirow{2}{*}{$\begin{array}{c}\text { Interruption } \\
\text { Time } \\
\text { (hr) }\end{array}$} & \multicolumn{2}{|c|}{$\begin{array}{l}\text { Total Activity } \\
\text { Ingested }\end{array}$} & \multicolumn{2}{|c|}{$\begin{array}{c}\text { Effective Dose Equivalent } \\
\text { (mrem) }\end{array}$} \\
\hline & & & & $(\mathrm{mCi})$ & (\%) & $\overline{\text { Newborn }}$ & 1-Yr-Old \\
\hline Tc-99m & 12 & minimum & 3 & $1.26 \mathrm{E}-02$ & $1.05 E-01$ & $9.33 \mathrm{E}+00$ & $4.57 \mathrm{E}+00$ \\
\hline \multirow[t]{17}{*}{ Sulfur Colloid } & & & 12 & $3.74 E-03$ & $3.11 \mathrm{E}-02$ & $2.76 \mathrm{E}+00$ & $1.35 \mathrm{E}+00$ \\
\hline & & & 24 & $7.38 \mathrm{E}-04$ & $6.15 E-03$ & $5.46 \mathrm{E}-01$ & $2.68 \mathrm{E}-01$ \\
\hline & & & 48 & $2.88 \mathrm{E}-05$ & $2.40 \mathrm{E}-04$ & $2.13 E-02$ & $1.05 E-02$ \\
\hline & & & 96 & $4.40 \mathrm{E}-08$ & $3.67 \mathrm{E}-07$ & $3.26 \mathrm{E}-05$ & $1.60 \mathrm{E}-05$ \\
\hline & & & 120 & $1.72 \mathrm{E}-09$ & $1.43 \mathrm{E}-08$ & $1.27 \mathrm{E}-06$ & $6.23 \mathrm{E}-07$ \\
\hline & & & 168 & $2.62 \mathrm{E}-12$ & $2.19 \mathrm{E}-11$ & $1.94 \mathrm{E}-09$ & $9.51 \mathrm{E}-10$ \\
\hline & & & 336 & $0.00 \mathrm{E}+00$ & $0.00 \mathrm{E}+00$ & $0.00 \mathrm{E}+00$ & $0.00 \mathrm{E}+00$ \\
\hline & & & 672 & $0.00 \mathrm{E}+00$ & $0.00 \mathrm{E}+00$ & $0.00 \mathrm{E}+00$ & $0.00 \mathrm{E}+00$ \\
\hline & & maxmimum & 3 & $1.76 \mathrm{E}-01$ & $1.47 \mathrm{E}+00$ & $1.30 \mathrm{E}+02$ & $6.38 \mathrm{E}+01$ \\
\hline & & & 12 & $8.30 \mathrm{E}-02$ & $6.92 \mathrm{E}-01$ & $6.14 \mathrm{E}+01$ & $3.01 \mathrm{E}+01$ \\
\hline & & & 24 & $3.05 \mathrm{E}-02$ & $2.54 \mathrm{E}-01$ & $2.26 \mathrm{E}+01$ & $1.11 E+01$ \\
\hline & & & 48 & $4.11 \mathrm{E}-03$ & $3.42 \mathrm{E}-02$ & $3.04 \mathrm{E}+00$ & $1.49 \mathrm{E}+00$ \\
\hline & & & 96 & $7.47 \mathrm{E}-05$ & $6.22 \mathrm{E}-04$ & $5.53 \mathrm{E}-02$ & $2.71 E-02$ \\
\hline & & & 120 & $1.01 \mathrm{E}-05$ & $8.39 \mathrm{E}-05$ & $7.45 \mathrm{E}-03$ & $3.65 \mathrm{E}-03$ \\
\hline & & & 168 & $1.83 E-07$ & $1.53 E-06$ & $1.35 \mathrm{E}-04$ & $6.64 \mathrm{E}-05$ \\
\hline & & & 336 & $1.48 \mathrm{E}-13$ & $1.23 \mathrm{E}-12$ & $1.09 \mathrm{E}-10$ & $5.36 \mathrm{E}-11$ \\
\hline & & & 672 & $0.00 \mathrm{E}+00$ & $0.00 \mathrm{E}+00$ & $0.00 \mathrm{E}+02$ & $0.00 \mathrm{E}+00$ \\
\hline Tc-99m & 30 & minimum & 3 & $4.78 \mathrm{E}-02$ & $1.59 \mathrm{E}-01$ & $1.95 \mathrm{E}+01$ & $9.02 \mathrm{E}+00$ \\
\hline \multirow[t]{17}{*}{ White Blood Cells* } & & & 12 & $5.10 \mathrm{E}-03$ & $1.70 \mathrm{E}-02$ & $2.08 \mathrm{E}+00$ & $9.63 \mathrm{E}-01$ \\
\hline & & & 24 & $2.58 \mathrm{E}-04$ & $8.61 E-04$ & $1.05 \mathrm{E}-01$ & $4.88 \mathrm{E}-02$ \\
\hline & & & 48 & $6.63 E-07$ & $2.21 E-06$ & $2.70 \mathrm{E}-04$ & $1.25 \mathrm{E}-04$ \\
\hline & & & 96 & $4.36 \mathrm{E}-12$ & $1.45 \mathrm{E}-11$ & $1.77 \mathrm{E}-09$ & $8.23 E-10$ \\
\hline & & & 120 & $1.11 \mathrm{E}-14$ & $3.69 \mathrm{E}-14$ & $4.50 \mathrm{E}-12$ & $2.09 \mathrm{E}-12$ \\
\hline & & & 168 & $0.00 \mathrm{E}+00$ & $0.00 \mathrm{E}+00$ & $0.00 \mathrm{E}+00$ & $0.00 \mathrm{E}+00$ \\
\hline & & & 336 & $0.00 \mathrm{E}+00$ & $0.00 \mathrm{E}+00$ & $0.00 \mathrm{E}+00$ & $0.00 \mathrm{E}+00$ \\
\hline & & & 672 & $0.00 \mathrm{E}+00$ & $0.00 \mathrm{E}+00$ & $0.00 \mathrm{E}+00$ & $0.00 \mathrm{E}+00$ \\
\hline & & maxmimum & 3 & $2.03 \mathrm{E}+00$ & $6.76 \mathrm{E}+00$ & $8.25 E+02$ & $3.83 E+02$ \\
\hline & & & 12 & $6.54 \mathrm{E}-01$ & $2.18 \mathrm{E}+00$ & $2.66 \mathrm{E}+02$ & $1.23 \mathrm{E}+02$ \\
\hline & & & 24 & $1.44 \mathrm{E}-01$ & $4.81 \mathrm{E}-01$ & $5.88 \mathrm{E}+01$ & $2.73 E+01$ \\
\hline & & & 48 & $7.05 \mathrm{E}-03$ & $2.35 \mathrm{E}-02$ & $2.87 \mathrm{E}+00$ & $1.33 \mathrm{E}+00$ \\
\hline & & & 96 & $1.68 \mathrm{E}-05$ & $5.61 \mathrm{E}-05$ & $6.84 \mathrm{E}-03$ & $3.17 E-03$ \\
\hline & & & 120 & $8.21 \mathrm{E}-07$ & $2.74 \mathrm{E}-06$ & $3.34 \mathrm{E}-04$ & $1.55 \mathrm{E}-04$ \\
\hline & & & 168 & $1.96 \mathrm{E}-09$ & $6.53 \mathrm{E}-09$ & $7.97 \mathrm{E}-07$ & $3.69 \mathrm{E}-07$ \\
\hline & & & 336 & $0.00 \mathrm{E}+00$ & $0.00 \mathrm{E}+00$ & $0.00 \mathrm{E}+00$ & $0.00 \mathrm{E}+00$ \\
\hline & & & 672 & $0.00 \mathrm{E}+00$ & $0.00 \mathrm{E}+00$ & $0.00 \mathrm{E}+00$ & $0.00 \mathrm{E}+00$ \\
\hline
\end{tabular}

* The dose estimates for Tc-99m labeled white blood cells are actually the dose estimates for Tc-99m pertechnetate, as it was assumed that activity released in breast milk from this product would be in the form of pertechnetate. 
Table B.4 Total Activity Ingested and Internal Radiation Doses Received from the Intake of Radiopharmaceuticals in Breast Milk Under Different Interruption Schedules (Continued)

\begin{tabular}{|c|c|c|c|c|c|c|c|}
\hline \multirow{2}{*}{$\begin{array}{l}\text { Radio- } \\
\text { pharmaceutical }\end{array}$} & \multirow{2}{*}{$\begin{array}{l}\text { Administered } \\
\text { Activity } \\
\text { (mCi) }\end{array}$} & \multirow[b]{2}{*}{ Concentration } & \multirow{2}{*}{$\begin{array}{c}\text { Interruption } \\
\text { Time } \\
\text { (hr) }\end{array}$} & \multicolumn{2}{|c|}{$\begin{array}{l}\text { Total Activity } \\
\text { Ingested }\end{array}$} & \multicolumn{2}{|c|}{$\begin{array}{l}\text { Effective Dose Equivalent } \\
\text { (mrem) }\end{array}$} \\
\hline & & & & $(\mathrm{mCi})$ & (\%) & Newborn & 1-Yr-Old \\
\hline \multirow[t]{18}{*}{ T1-201 Chloride* } & 3 & . minimum & 3 & $1.22 \mathrm{E}-02$. & $4.08 \dot{\mathrm{E}}-01$ & $1.94 \mathrm{E}+02$ & $1.11 \mathrm{E}+02$ \\
\hline & & -5 & 12 & $9.72 \mathrm{E}-03$ & $3.24 \mathrm{E}-01$ & $1.54 \mathrm{E}+02$ & $8.78 \mathrm{E}+01$ \\
\hline & & & 24 & $7.49 \mathrm{E}-03$ & $2.50 \mathrm{E}-01$ & $1.18 \mathrm{E}+02$ & $6.74 \mathrm{E}+01$ \\
\hline & & & 48 & $4.92 \mathrm{E}-03$ & $1.64 \mathrm{E}-01$ & $7.73 E+01$ & $4.42 \mathrm{E}+01$ \\
\hline & & & 96 & $2.45 \mathrm{E}-03$ & $8.17 \mathrm{E}-02$ & $3.84 \mathrm{E}+01$ & 2.19E+01 \\
\hline & & & 120 & $1.76 \mathrm{E}-03$ & $5.86 \mathrm{E}-02$ & $2.76 \mathrm{E}+01$ & $1.57 \mathrm{E}+01$ \\
\hline & & & 168 & $9.10 \mathrm{E}-04$ & $3.03 E-02$ & $1.43 \mathrm{E}+01$ & $8.15 \mathrm{E}+00$ \\
\hline & & & 336 & $9.11 \mathrm{E}-05$ & $3.04 \mathrm{E}-03$ & $1.43 \mathrm{E}+00$ & $8.15 \mathrm{E}-01$ \\
\hline & & & 672 & $9.13 \mathrm{E}-07$ & $3.04 \mathrm{E}-05$ & $1.43 \mathrm{E}-02$ & $8.17 \mathrm{E}-03$ \\
\hline & & maxmimum & 3 & $2.37 \mathrm{E}-02$ & $7.91 \mathrm{E}-01$ & $3.67 \mathrm{E}+02$ & $2.10 \mathrm{E}+02$ \\
\hline & & & 12 & $2.12 \mathrm{E}-02$ & $7.08 \mathrm{E}-01$ & $3.29 \mathrm{E}+02$ & $1.87 \mathrm{E}+02$ \\
\hline & & & 24 & $1.86 \mathrm{E}-02$ & $6.21 \mathrm{E}-01$ & $2.88 \mathrm{E}+02$ & $1.65 \mathrm{E}+02$ \\
\hline & & & 48 & $1.51 \mathrm{E}-02$ & $5.04 \mathrm{E}-01$ & $2.34 \mathrm{E}+02$ & $1.34 \mathrm{E}+02$ \\
\hline & & & 96 & $1.16 \mathrm{E}-02$ & $3.88 \mathrm{E}-01$ & $1.80 \mathrm{E}+02$ & $1.03 E+02$ \\
\hline & & & 120 & $1.07 \mathrm{E}-02$ & $3.56 \mathrm{E}-01$ & $1.65 \mathrm{E}+02$ & $9.43 \mathrm{E}+01$ \\
\hline & & & 168 & $9.41 \mathrm{E}-03$ & $3.14 \mathrm{E}-01$ & $1.45 \mathrm{E}+02$ & $8.31 \mathrm{E}+01$ \\
\hline & & & 336 & $6.71 \mathrm{E}-03$ & $2.24 \mathrm{E}-01$ & $1.04 \mathrm{E}+02$ & $5.93 \mathrm{E}+01$ \\
\hline & & & 672 & $3.53 \mathrm{E}-03$ & $1.18 \mathrm{E}-01$ & $5.45 \mathrm{E}+01$ & $3.11 \mathrm{E}+01$ \\
\hline
\end{tabular}

\footnotetext{
* Includes the dose from radioactive contaminants. See Section B.1 CALCULATIONAL METHOD for details.
} 
Table B.5 Potential Doses to Breast-Feeding Infants from Radiopharmaceuticals Administered to a Woman if No Interruption of Breast-Feeding and Recommendations on Interruption of Breast-Feeding

\begin{tabular}{|c|c|c|c|c|c|}
\hline $\begin{array}{l}\text { Radio- } \\
\text { pharmaceutical }\end{array}$ & $\begin{array}{l}\text { Maximum } \\
\text { Administered } \\
\text { Activity }{ }^{1} \\
\text { (mCi) (MBq) }\end{array}$ & $\begin{array}{l}\text { Internal Dose to } \\
\text { Infant if No } \\
\text { Interruption of } \\
\text { Breast-Feeding } \\
\text { (mrem) }\end{array}$ & $\begin{array}{l}\text { External Dose to } \\
\text { Infant if No } \\
\text { Interruption of } \\
\text { Breast-Feeding }{ }^{3} \\
\text { (mrem) }\end{array}$ & $\begin{array}{l}\text { Instructions } \\
\text { Required? }\end{array}$ & $\begin{array}{l}\text { Recommendation } \\
\text { on Interruption of } \\
\text { Breast-Feeding }^{5}\end{array}$ \\
\hline Cr-51 EDTA & $0.05(1.85)$ & $<0.01$ & 2 & no & None \\
\hline Ga-67 Citrate & $5(185)$ & $300-10,000$ & 200 & yes & $\begin{array}{l}\text { Interruption for } \\
\text { about } 1 \text { month }\end{array}$ \\
\hline $\mathrm{I}-123 \mathrm{mIBG}^{6}$ & $10(370)$ & 300 & 100 & yes & $\begin{array}{l}\text { Interruption for } \\
\text { about } 24 \text { hours }\end{array}$ \\
\hline $\mathrm{I}-123 \mathrm{OIH}^{6}$ & $2(74)$ & 4-30 & 30 & no & None \\
\hline $\begin{array}{l}\text { I-123 Sodium } \\
\text { Iodide (NaI) }\end{array}$ & $0.4(14.8)$ & $60-70$ & 5 & no & None \\
\hline $\mathrm{I}-125 \mathrm{OIH}^{6}$ & $0.01(0.37)$ & 0.2 & 10 & no & None \\
\hline $\mathrm{I}-131 \mathrm{OIH}^{6}$ & $0.3(11.1)$ & $3-20$ & 70 & no & None \\
\hline $\begin{array}{l}\text { I-131 Sodium } \\
\text { lodide }(\mathrm{NaI})\end{array}$ & $150(5,550)$ & very large & $\mathrm{NA}^{7}$ & yes & Complete cessation \\
\hline $\begin{array}{l}\text { In-111 } \\
\text { White Blood Cells }\end{array}$ & $0.5(18.5)$ & $40-200$ & 60 & yes & $\begin{array}{l}\text { Interruption for } \\
\text { about } 1 \text { week }\end{array}$ \\
\hline Tc-99m DISIDA & $8(300)$ & $7-20$ & 20 & no & None \\
\hline Tc-99m DTPA & $20(740)$ & $0.3-6$ & 50 & no & None \\
\hline $\begin{array}{l}\text { Tc-99m DTPA } \\
\text { Aerosol }^{8}\end{array}$ & $1(37)$ & $0.01-0.3$ & 3 & no & None \\
\hline $\begin{array}{l}\text { Tc-99m } \\
\text { Glucoheptonate }\end{array}$ & $20(740)$ & $5-10$ & 50 & no & None \\
\hline Tc-99m HAM & $8(300)$ & $20-50$ & 20 & no & None \\
\hline Tc-99m MAA & $4(148)$ & $4-300$ & 10 & yes & $\begin{array}{l}\text { Interruption for } \\
\text { about } 12 \text { hours }\end{array}$ \\
\hline Tc-99m MAG39 & $10(370)$ & $0.2-3$ & 30 & no & None \\
\hline Tc-99m MDP & $20(740)$ & $4-5$ & 50 & no & None \\
\hline Tc-99m MIBI & $30(1,110)$ & $1-10$ & 80 & no & None \\
\hline $\begin{array}{l}\text { Tc-99m O4 } \\
\text { (Pertechnetate) }\end{array}$ & $30(1,110)$ & $20-800$ & 80 & yes & $\begin{array}{l}\text { Interruption for } \\
\text { about } 24 \text { hours }\end{array}$ \\
\hline Tc-99m PYP & $20(740)$ & $5-20$ & 50 & no & None \\
\hline
\end{tabular}


Table B.5 Potential Doses to Breast-Feeding Infants from Radiopharmaceuticals Administered to a Woman if No Interruption of Breast-Feeding and Recommendations on Interruption of Breast-Feeding (Continued)

\begin{tabular}{|c|c|c|c|c|c|}
\hline $\begin{array}{l}\text { Radio- } \\
\text { pharmaceutical }\end{array}$ & $\begin{array}{l}\text { Maximum } \\
\text { Administered } \\
\text { Activity }^{1} \\
\text { (mCi) (MBq) }\end{array}$ & $\begin{array}{l}\text { Internal Dose to } \\
\text { Infant if No } \\
\text { Interruption of } \\
\text { Breast-Feeding }{ }^{2} \\
\text { (mrem) }\end{array}$ & $\begin{array}{l}\text { External Dose to } \\
\text { Infant if No } \\
\text { Interruption of } \\
\text { Breast-Feeding }{ }^{3} \\
\text { (mrem) }\end{array}$ & $\begin{array}{l}\text { Instructions } \\
\text { Required? }^{4}\end{array}$ & $\begin{array}{l}\text { Recommendation } \\
\text { on Interruption of } \\
\text { Breast-Feeding }\end{array}$ \\
\hline $\begin{array}{l}\text { Tc-99m RBC } \\
\text { In Vitro Labeling }\end{array}$ & $20(740)$ & $1-2$ & 50 & no & None \\
\hline $\begin{array}{l}\text { Tc-99m RBC } \\
\text { In Vivo Labeling }\end{array}$ & $20(740)$ & $0.3-100$ & 50 & yes & $\begin{array}{l}\text { Interruption for } \\
\text { about } 6 \text { hours }\end{array}$ \\
\hline $\begin{array}{l}\text { Tc-99m } \\
\text { Sulfur Colloid }\end{array}$ & $12(444)$ & $9-100$ & 30 & yes & $\begin{array}{l}\text { Interruption for } \\
\text { about } 6 \text { hours }\end{array}$ \\
\hline $\begin{array}{l}\text { Tc-99m } \\
\text { White BloodCells }^{10}\end{array}$ & $5(185)$ & $20-800$ & 10 & yes & $\begin{array}{l}\text { Interruption for } \\
\text { about } 24 \text { hours }\end{array}$ \\
\hline T1-201 Chloride & $3(111)$ & $200-400$ & 60 & yes & $\begin{array}{l}\text { Interruption for } \\
\text { about } 2 \text { weeks }\end{array}$ \\
\hline
\end{tabular}

1. Maximum activity normally administered.

2. Doses were calculated using the maximum administered activities shown in Column 2. If smaller activities were to be administered, the doses would be proportionally smaller. The doses were calculated for newborn infants; doses to one-yearold infants would be less than half the doses shown. If a dose range is shown, the range is due to individual variability and measurement variability as indicated by different measurements of concentrations in breast milk as shown in Table B.2. All values have been rounded to one significant figure. The external dose, typically small relative to the internal dose, is considered separately under Column 4.

3. Dose to the infant from external radiation only during breast-feeding assuming no interruption of breast-feeding. Doses were calculated using an occupancy factor of 0.16 and an effective distance from source to receptor tissue of 0.2 meter. All values have been rounded to one significant figure.

4. The decision on whether instructions are required by 10 CFR 35.75 is based on the sum of the maximum value of the internal dose range for the newborn infant plus the external dose assuming no interruption of breast-feeding.

5. The duration of interruption is selected to reduce the maximum dose to a newborn infant to less than 0.1 rem. The actual doses that would be received by most infants would be far below $0.1 \mathrm{rem}$. The physician may use discretion in the recommendation, increasing or decreasing the duration of interruption.

6. No consideration of free iodide for this analysis.

7. Not applicable (NA) because complete cessation of breast-feeding is assumed.

8. A fraction of the administered activity (i.e., 0.41) was treated as intravenous DTPA.

9. Treated as Tc-99m DTPA for this analysis.

10. Treated as Tc-99m pertechnetate for this analysis. 


\section{B.3 REFERENCES}

AH85

Ahlgren, L., S. Ivarsson, L.

Johansson, S. Mattsson, B. Nosslin, 1985, "Excretion of Radionuclides in Human Breast Milk After the Administration of Radiopharmaceuticals," J. Nucl. Med. 26:1085.

BE73 Berke, R.A., E.C. Hoops, J.C. Kereiakes, E.L. Saenger, 1973, "Radiation Dose to Breast-Feeding Child After Mother has ${ }^{99 m}$ Tc-MAA Lung Scan," J. Nucl. Med. 14:51.

BU86 Butt, D. and K. Szaz, 1986, "Indium-111 Radioactivity in Breast Milk," Brit. J Radiol, 59:80.

CR87 Cristy, M. and K. Eckerman, 1987, "Specific Absorbed Fractions of Energy at Various Ages from Internal Photons Sources," ORNL/TM-8381 V1-V7, Oak Ridge National Laboratory, Oak Ridge, TN.

CR85 Cranage, R. and M. Palmer, 1985, "Breast-Milk Radioactivity After ${ }^{92 m}$ Tc-MAA Lung Studies," Eur. J. Nucl. Med. 11:257.

DY88 Dydek, G.J. and P.W. Blue, 1988, "Human Breast Milk Excretion of Iodine-131 Following Diagnostic and Therapeutic Administration to a Lactating Patient with Graves' Disease," J. Nucl. Med. 29:407.

GR83 Greener, A.W., P.J. Conte, K.D. Steidley, 1983 "Update in Gallium-67 Concentration in Human Breast Milk," J. Nucl. Med. Technol. 11:171.

Hesselwood, S.R., J.R. Thornback, J.M. Brameld, 1988, "Indium-111 in Breast Milk Following Administration of Indium-111-Labeled Leukocytes," J. Nucl. Med. 29:1301.
HE86

Hedrick, R.H., R.N. Di Simone, R.L. Keen, 1986, "Radiation Dosimetry from Breast Milk Excretion of Radioiodine and Pertechnetate," J. Nucl. Med. 27:1569.

HE79

JO95

KE94

LA71

MA81

Heaton, B., 1979, "The Build Up of Technetium in Breast Milk Following the Administration of ${ }^{99} \mathrm{Tc}^{\mathrm{m}} \mathrm{O}_{4}$ Labelled Macroaggregated Albumin," Br. J. Radiol. 52:149.

Johnston, R.E., S.K. Mukherji, J.R. Perry, M.G. Stabin, 1996, "Radiation Dose from Breastfeeding Following Administration of Tl-201," J. Nucl. Med. 37:2079.

Kettle, A.G., M.J. O'Doherty, P.J. Blower, 1994, "Secretion of [ $\left.{ }^{123} \mathrm{I}\right]$ Iodide in Breast Milk Following Administration of [ $\left.{ }^{123} \mathrm{I}\right]$ metaiodobenzylguanidine," Eur. J. Nucl. Med. 21:181.

Larson, S.M. and G.L. Schall, 1971 "Gallium-67 Concentration in Human Breast Milk," (letter to the editor) JAMA 218(2):257.

Mattsson, S., L. Johansson, B. Nosslin, L. Ahlgren, 1981, "Excretion of Radionuclides in Human Breast Milk Following Administration of ${ }^{125} \mathrm{I}$-fibrinogen, ${ }^{99} \mathrm{Tc}^{\mathrm{m}}-\mathrm{MAA}$ and ${ }^{\text {SI CR-EDTA," In Third International }}$ Radiopharmaceutical Dosimetry Symposium; eds. E.E. Watson, A.T. Schlafke-Stelson, J.L. Coffey, R.J. Cloutier; HHS Publication FDA 818166, U.S. Dept. of Health and Human Services, Food and Drug Administration, Rockville, MD, pp 102-110. 
MO89a Mountford P.J. and A.J. Coakley, 1989, "A Review of the Secretion of Radioactivity in Human Breast Milk: Data, Quantitative Analysis and Recommendations," Nucl. Med. Commun. 10:15.

MO89b Mountford, P.J. and A.J. Coakley, 1989, "Secretion of Radioactivity in Breast Milk Following Administration of ${ }^{123}$ I Hippuran," Br. J. Radiol. 62:388.

MO87 Mountford, P.J. and A.J. Coakley, 1987 "Breast Milk Radioactivity

Following Injection of ${ }^{99 m} \mathrm{Tc}-$ Pertechnetate and ${ }^{99} \mathrm{Tc}$ -

Glucoheptonate," Nucl. Med. Commun. 8:839.

MO85a Mountford, P.J. and A.J. Coakley, 1985, "Excretion of Radioactivity in Breast Milk After an Indium Leukocyte Scan," J. Nucl. Med. 26:1096.

MO85b Mountford, P.J., A.J. Coakley, F.M. Hall, 11985 "Excretion of Radioactivity in Breast Milk Following Injection of Tc-99m DTPA," Nuc. Med. Commun. 6:341.

MO84 Mountford, P.J., F.M. Hall, C.P. Wells, A.J. Coakley, 1984, "BreastMilk Radioactivity After a Tc-99m DTPA Aerosol/Tc-99m MAA Lung Study," J. Nucl. Med. 25:1108.

MU89 Murphy, P.H., C.W. Beasley, W.H. Moore, and M.G. Stabin, 1989, "Thallium-201 in Human Milk: Observations and Radiological Consequences," Health Physics 56:539.

NU52 Nurnberger, C.E. and A. Lipscomb, 1952, "Transmission of Radioiodine $\left(\mathrm{I}^{\mathbf{1 3 1}}\right)$ to Infants Through Human Maternal Milk," JAMA 150:1398.

PI79

R094

RO90

Ogunleye, O.T., 1983, "Assessment of Radiation Dose to Infants from Breast Milk Following the Administration of ${ }^{99 m} \mathrm{Tc}$ Pertechnetate to Nursing Mothers," Health Physics 45:149.

Pittard III, W.B., K. Bill, B.D. Fletcher, 1979, "Excretion of Technetium in Human milk," J. Pediatrics 94:605.

Robinson, P.S., P. Barker, A. Campbell, P. Henson, I. Surveyor, P.R. Young, 1994, "Iodine-131 in Breast Milk Following Therapy for Thyroid Carcinoma," J. Nucl. Med. 35:1797.

Rose, M.R., M.C. Prescott, KJ. Herman, 1990, "Excretion of Iodine-123 Hippuran, Technetium-99m Red Blood Cells, and Technetium-99m Macroaggregrated Albumin into Breast Milk," J. Nucl. Med. 31:978.

RU94 Rubow, S., J. Klopper, H. Wasserman, B: Baard, M. van Niekerk, 1994 "The Excretion of Radiopharmaceuticals in Breast Milk: Additional Data and Dosimetry," Eur. J. Nucl. Med. 21:144.

RU91 Rubow, S., J. Klopper, P. Scholtz, 1991, "Excretion of Gallium-67 in Human Breast Milk and Its Inadvertent Ingestion by a 9-MonthOld Child," Eur. J. Nucl. Med. 18:829.

RU88 Rubow, S. and J. Klopper, 1988, "Excretion of Radioiodine in Human Milk Following a Therapeutic Dose of I-131," Eur. J. Nucl. Med. 14:632.

RU78 Rumble, W.F., R.L. Aamodt, A.E. Jones, R. Henkin, 1978, "Accidental Ingestion of Tc-99m in Breast Milk

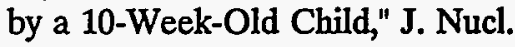
Med. 19:913. 
ST95 Stabin, M., 1995, "Internal Dosimetry in Pediatric Nuclear Medicine," In Pediatric Nuclear Medicine; ed.

S. Treves; Springer Verlag, NY.

T076

Tobin, R.E. and P.B. Schneider, 1976 "Uptake of ${ }^{67} \mathrm{Ga}$ in the Lactating Breast and its Persistence in Milk: Case Report," J. Nucl. Med. 17:1055.

VA71 Vagenakis, A.G., C.M. Abreau, L.E. Braverman, 1971 "Duration of Radioactivity in the Milk of a Nursing Mother Following $\mathrm{Tc}$ Aministration," J. Nucl. Med. 12:188.
WE94 Weiner, R.E. and R.P. Spencer, "Quantification of Gallium-67 Citrate in Breast Milk," Clin. Nucl. Med.

18:763.

WE60 Weaver, J.C., M.L. Kamm, R.L. Dobson, 1960 "Excretion of Radioiodine in Human Milk," JAMA 173:872.

WY73 Wyburn, J.R., 1973, "Human Breast Milk Excretion of Radionuclides Following Administration of Radiopharmaceuticals," J. Nucl. Med. 14:115. 
Regulatory Analysis on Criteria for the Release of Patients Administered Radioactive Material

Final Report

\begin{tabular}{|c|r|}
\hline 3. & \multicolumn{2}{|c}{ DATE REPORT PUBLISHED } \\
\hline MONTH & YEAR \\
February & 1997 \\
\hline
\end{tabular}

4. FIN OR GRANT NUMBER

5.AUTHOR(S)

6. TYPE OF REPORT

S. Schneider, S.A. McGuire

Final

7. PERIOD COVERED (inelusive Dates)

8. PERFORMING ORGANIZATION - NAME AND ADDRESS (If NRC, provide Division, Office or Region, U.S. Nucloar Regulatory Commission, end mailing address; if contractor, provide namo and mailling address.

Division of Regulatory Applications

Office of Nuclear Regulatory Research

U.S. Nuclear Regulatory Commission

Washington, DC 20555-0001

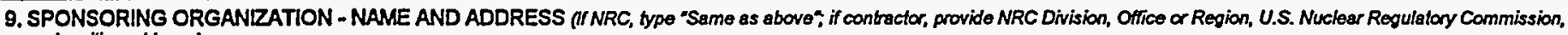
and malling addross.)

Same as 8. above.

\section{SUPPLEMENTARY NOTES}

S. Schneider, NRC Project Manager

\section{ABSTRACT (200 words or less)}

This regulatory analysis was developed to respond to three petitions for rulemaking to amend 10 CFR Parts 20 and 35 regarding release of patients administered radioactive material. The petitions requested revision of these regulations to remove the ambiguity that existed between the 1-mSv (0.1-rem) total effective dose equivalent (TEDE) public dose limit in Part 20, adopted in 1991, and the activity-based release limit in $10 \mathrm{CFR} 35.75$ that, in some instances, would permit release of individuals in excess of the current public dose limit. Three alternatives for resolution of the petitions were evaluated. Under Alternative 1, NRC would amend its patient release criteria in 10 CFR 35.75 to match the annual public dose limit in Part 20 of $1 \mathrm{mSv}(0.1$ rem) TEDE. Alternative 2 would maintain the status quo of using the activity-based release criteria currently found in $10 \mathrm{CFR} 35.75$. Under Alternative 3 , the NRC would revise the release criteria in 10 CFR 35.75 to specify a dose limit of $5 \mathrm{mSv}(0.5 \mathrm{rem})$ TEDE. The evaluation demonstrates that adoption of Alternative 1 would be considerably more expensive to the public compared to Alternative 2 (the status quo), primarily due to increased health care costs associated with more patients remaining in the hospital than under the current activity-based requirements. The evaluation also demonstrates that adoption of the 5-mSv (0.5-rem) dose limit under Alternative 3 would result in a higher net value to the public compared to Alternative 2 (the status quo), primarily due to lower health care costs and the increased psychological benefits to patients and their families by permitting earlier release from the hospital. Based on this analysis, the decision was made that adoption of the 5-mSv (0.5-rem) TEDE limit is consistent with the provisions in 10 CFR 20.1301(c), and the recommendations of the international Commission on Radiological Protection that an individual be allowed to receive annual doses up to $5 \mathrm{mSv}(0.5 \mathrm{rem})$ TEDE under certain circumstances. Further, it no longer restricts patient release to a specific activity, and therefore, permits release of patients with activities that are greater than currently allowed. The primary benefit is in reduced hospital stays that provide emotional benefits to patients and their families, and result in lower health care costs

12. KEY WORDSIDESCRIPTORS (Ust words or phrases that will assist researchers in locating the report) 13. AVALLABILTY STATEMENT

10 CFR 35.75

patient release criteria

lodine-131

therapeutic administration

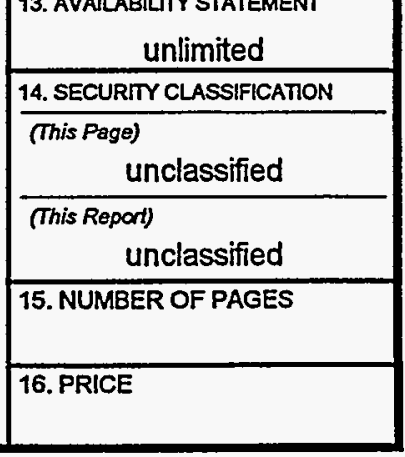

